4 norden 



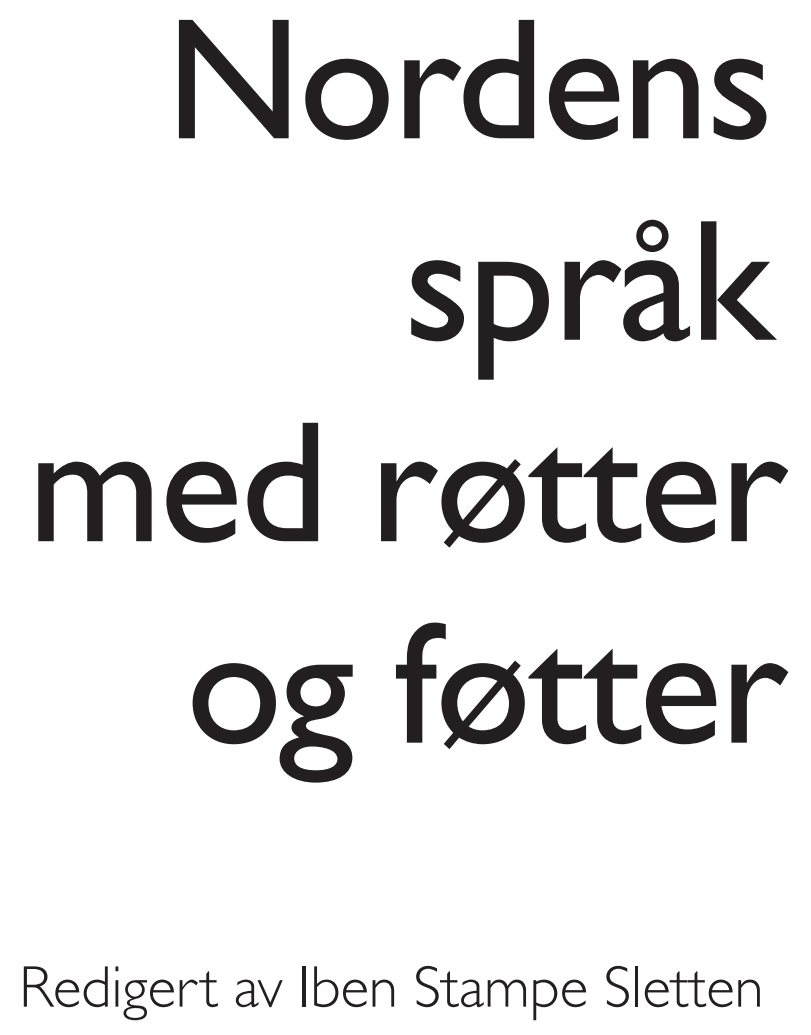

Nord 2004: 9 


\section{Nordens språk med røtter og føtter}

Nord 2004:9

(C) Nordisk Ministerråd, København 2004

ISBN 92-893-1042-1

Forlagsredaktør: Iben Stampe Sletten

Grafisk projektledelse: Kjell Olsson

Design: Carl-H.K. Zakrisson, www.polytype.dk

Illlustrasjoner: Ivar Gjørup, www.egoland.dk

Kart: John Fowlie/studio16a

Trykk: Akaprint A/S, Århus 2005

Opplag: 2000

Trykt på miljøvennlig papir som oppfyller kravene

i den nordiske miljøsvanemerkeordningen.

Printed in Denmark

541

\section{Nordisk Ministerråd}

Store Strandstræde 18

DK-1255 København K

Telefon (+45) 33960200

Telefaks (+45) 33960202

www.norden.org

\section{Nordisk Råd}

Store Strandstræde 18

DK-1255 København K

Telefon (+45) 33960400

Telefaks (+45) 33111870

\section{Nordisk Ministerråd}

ble opprettet i 1971 som et samarbeidsorgan mellom de nordiske lands regjeringer. Ministerrådet fremlegger forslag til Nordisk Råds sesjoner, viderefører rådets rekommandasjoner, rapporterer til Nordisk Råd om samarbeidets resultater og leder arbeidet innenfor de forskjellige emneområder. Samarbeidet koordineres av samarbeidsministrene som er utpekt av det enkelte lands regjering. Ministerrådet holder møter i forskjellige sammensetninger, avhengig av hvilke spørsmål som skal behandles.

\section{Nordisk Råd}

ble opprettet i 1952 som et samarbeidsorgan mellom de folkevalgte forsamlinger og regjeringer i Danmark, Island, Norge og Sverige. Finland kom med i 1955. Færøyenes, Grønlands og Ålands delegasjoner inngår i henholdsvis Danmarks Rikes og Finlands delegasjoner. Rådet består av 87 medlemmer. Nordisk Råd er initiativtagende og rådgivende og har kontrollerende oppgaver i det nordiske samarbeidet. Nordisk Råds organer er plenarforsamlingen, presidiet og utvalgene.

\section{Det nordiske språksamarbeidet}

Det språklige fellesskapet er en grunnleggende forutsetning for det folkelige, kulturelle, økonomiske og politiske samarbeidet i Norden. Det språkpolitiske arbeidet ved Nordisk Ministerråd koordineres $\mathrm{og}$ ledes av en styringsgruppe som har følgende hovedoppgaver: 1) fungere som sakkyndig organ for Nordisk Ministerråd og Nordisk Råd når det gjelder nordiske språkspørsmål og nordisk språkpolitikk, 2) fungere som samarbeidsorgan for de nordiske språknemndene og utenlandslektorene, 3) fungere som styringsgruppe for det tverrgående støtteprogrammet
Nordplus språk og dermed ha det overordnede ansvaret for programmet. Styringsgruppen for Nordisk Ministerråds språksamarbeid, Nordens språkråd, skal arbeide med utgangspunkt i følgende målsettinger: fremme internordisk språkforståelse, styrke kunnskapen om språkene i Norden, fremme demokratisk språkpolitikk og språksyn i Norden, styrke de nordiske språkenes stilling i og utenfor Norden. I Nordisk Råd, de nordiske parlamentenes samarbeidsorgan, har Kulturog utdannelsesutvalget ansvaret for spørsmål som vedrører språksamarbeidet. 


\section{Innhold}

Forord / Nordens språkråd 9

Nettutgaven av «Nordens språk med røtter og føtter» / Iben Stampe Sletten 11

Oversikt over nettmaterialets oppbygning 12

Presentasjon av artikler 13

Nordisk språkhistorie 13

Nåtidens røtter i fortiden 13

Det mangfoldige Norden 14

Hver mann sitt språk - dialekter i dag 15

Det engelske språk - trussel eller ressurs? 16

Språk i bevegelse - men hvor går det hen? 17

Nordiske språk i fortid og nåtid / Arne Torp 19

Språka i Norden: Tre familier - mange språk 23

Den indoeuropeiske språkfamilien 27

Stamtremodell og nordiske språk 30

Den germanske språkgruppa 31

Den germanske lydforskyvinga 32

Arveord, lånord og importord 33

Skandinavia: Ulike språk eller bare dialekter? 35

Avstandsspråk 36

Standardspråk 40

Dialektkontinua og standardspråk innafor det germanske språkområdet 41

Tre eller fem språk? 43

Hvorfor bokmål og nynorsk? 44

Moderne nordiske språk $\quad 44$ 
Stamtremodellen om igjen $\quad 46$

Tjukk I 49

Mjuke konsonanter 49

Skarre-r 49

Historisk inndeling av nordiske språk etter bølgemodellen

Fra urnordisk til vikingtid 52

Runeskrifta 52

Østnordisk og vestnordisk 52

I høgmellomalderen: nordnordisk og sørnordisk 56

Nyere tid: øynordisk og skandinavisk 59

Hvorfor er skandinavisk og øynordisk avstandsspråk? 60

Forskjellig bøying 60

Forskjellig uttale 65

Orda betyr mest for forståelsen 66

Er stamtremodellen moden for skraphaugen? 68

Den skandinaviske nabospråksforståelsen

- et hovedelement i den nordiske samkjensla 70

Nabospråksforståelsen i fare? 73

Litteratur 74

Internett 74

Finsk / Kaisa Häkkinen 75

Finsk og dets slektninger 75

Finnenes forhistorie 76

Finske dialekter 76

Faser i det finske språkets historie 79

Oldtidsfinsk og middelalderfinsk 79

Gammel skriftfinsk 80

Eldre nåfinsk 80

Nåfinsk 81 
Lydstruktur i nåfinsk 82

Grunnleggende morfologiske trekk 84

Hovedtrekk i syntaksen (setningslæren) 90

Ordforrådet 91

Finsk i dag og i morgen 94

Litteratur 95

Internett 95

\section{Samiske språk / Mikael Svonni 97}

Det samiske bosettingsområdet og samiske språk 97

Historiske kontakter 98

Perioden fra år 4000 til år 2000 før vår tidsregning 99

Perioden fra år 2000 før vår tidsregning til år 1000

Antall som snakker samisk 100

Oppbygningen av samisk 101

Bøyning av verb 101

Stadieveksling 102

Kasus 102

Avledning av ord 103

Tempus og modus 104

Skrivemåte og språklyd 105

Skriftspråk 106

Språkets situasjon i samfunnet 107

Lovgivning 107

Samisk i undervisningen 108

Samisk i mediene 109

Litteratur og musikk 109

Samfunnet ellers 110

Litteratur 111

Internett 111 
Kalaallisut - grønlandsk / Carl Christian Olsen 113

Forholdet mellom tale- og skriftspråk 113

Grønlandske dialekter 116

Karakteristika ved kalaallisut 117

Et agglutinerende språk 117

Et ergativt språk 117

Morfologiske forhold 118

Kasusforhold 120

Personendelser 121

Enklitiske endelser 122

Hovedverb og hjelpeverb 122

Utviklingen av kalaallisut som skriftspråk 123

Standardgrønlandsk 124

Lånord og fremmedord 125

Språkets status 126

Litteratur 127

Internett 127 


\section{Forord}

Nordens språk med røtter og fotter er et fellesnordisk lærebokprosjekt. I år 2000 tok Nordisk Ministerråds språkpolitiske referansegruppe initiativ til utarbeidelsen av en nordisk språkhistorie rettet mot elever i videregående skole. Prosjektet ble gjennomført i samarbeid med NORDSPRÅK, en sammenslutning av nordiske morsmålslærere og lærere som underviser i et nordisk språk som fremmedspråk. Steen Svava Olsen ble tilknyttet som prosjektleder, mens den endelige redaksjon ble overdratt til Iben Stampe Sletten.

Nordens språkråd* vil gjerne takke NORDSPRÅK for samarbeidet og særlig Iben Stampe Sletten for en overordentlig stor og helt avgjørende innsats i prosjektets siste fase.

Med dette utgivelsesprosjektet er det hensikten å styrke især unge menneskers refleksjon over språkets betydning og å øke bevisstheten om at det i Norden finnes et særlig språklig og kulturelt fellesskap betinget av historiske og politiske forhold. Målet er å styrke interessen både for det fellesnordiske perspektivet og for den språklige siden av morsmålsundervisningen.

\footnotetext{
* Nordens språkråd ble etablert 1. januar 2004 til erstatning for Nordisk Ministerråds språkpolitiske referansegruppe og Nordisk språkråd.
}

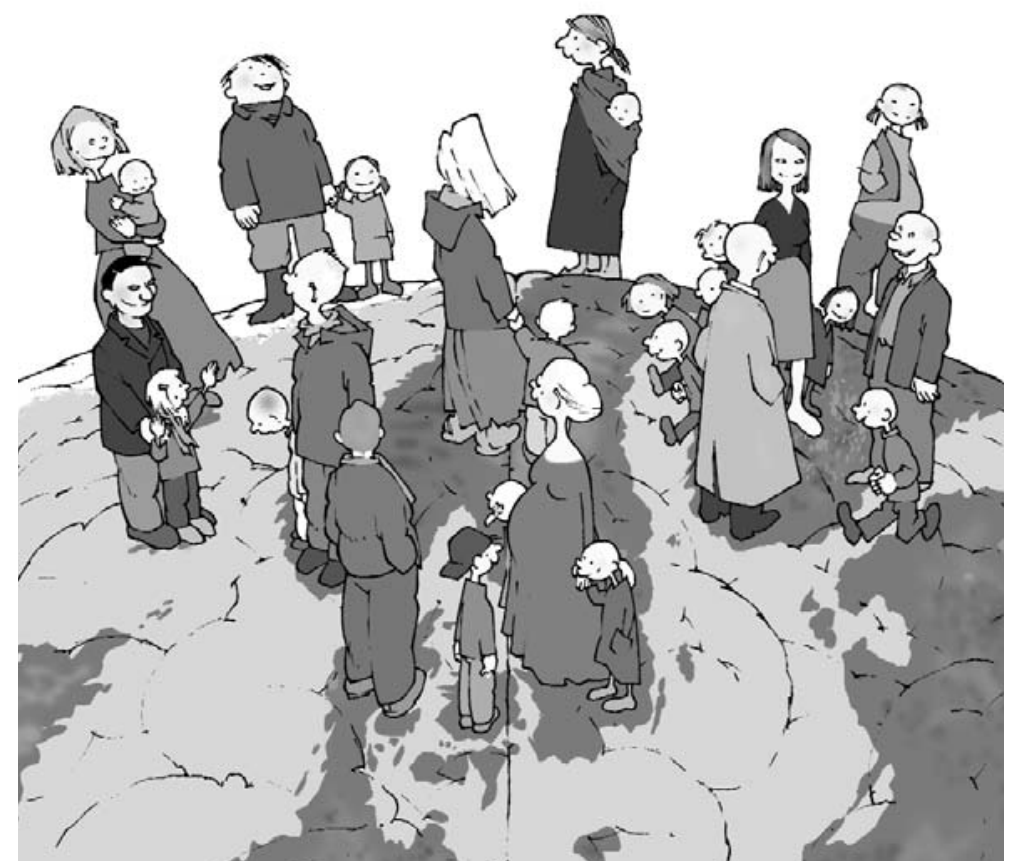


Nordens språk med røtter og føtter utgis på svensk, norsk, dansk, færøysk og islandsk som undervisningsbok for den videregående skole i alle de nordiske land - og er dessuten tilgjengelig på internett fra Nordisk Ministerråds nettportal: www.nordskol.org. Her ligger videre et omfattende materiale av kortere diskuterende artikler på dansk, svensk og norsk om for eksempel nordisk språk og kultur, om dialekters status i forskjellige land og om små språks stilling og fremtid i en globaliseringstid. Nettmaterialet kan man enkelt få overblikk over ved å lese nedenstående introduksjon, hvor de enkelte artikler presenteres. Dette materialet vil løpende kunne utvides med nye artikler, oppgaver osv.

Nordens språkråd håper at lærere på alle nivåer vil forstå å utnytte både boken og nettmaterialet i en undervisning som kan bidra til å realisere det språklige fellesskapet i hele Norden slik befolkningene ønsker.

November 2004

for Nordens språkråd

Guðrún Kvaran

formann 


\section{Nettutgaven av «Nordens språk med røtter og føtter»}

Du kan få adgang til en utvidet versjon av Nordens språk med røtter og fotter fra Nordisk Ministerråds nettportal: www.nordskol.org. Nettmaterialet består delvis av bokens fire artikler (kapittel 2), delvis av en rekke språkhistoriske og språkpolitiske artikler, som er tematisk gruppert i kapitlene 3-7.

I kapittel 3 vises det fra forskellige vinkler hvordan fortiden er til stede i nåtidens språkbruk. Kapittel 4 handler om sammenhengen mellom språk og kulturell identitet. Kapittel 5 ser på bruken av dialekter og deres status i dag, mens kapittel 6 diskuterer hvordan språkene i Norden påvirkes av kontakten med engelsk. Endelig diskuteres de nordiske språks fremtid i en globaliseringstid i kapittel 7.

Nedenfor står en oversikt over nettutgaven av Nordens språk med røtter og fotter samt en kort presentasjon av artiklenes innhold.

Alle artikler i kapittel 2 er tilgjengelige på islandsk, færøysk, norsk, svensk og dansk, mens de kortere artiklene i kapitlene 3-7 er skrevet på enten norsk, svensk eller dansk. Det er således rik mulighet for å lese fagtekster på alle nordiske språk i:

- Norđurlandamálin med rótum og fótum

- Norđurlandamál vid rótum og fótum

- Nordens språk med rotter og fotter

- Nordens språk med rötter och fötter

- Nordens sprog med rødder og fødder

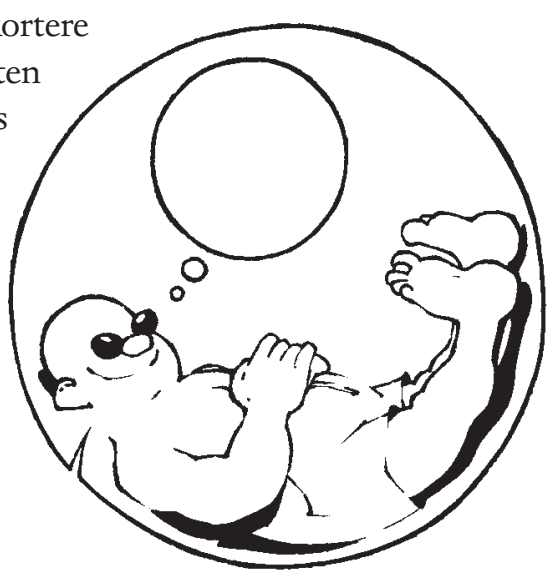




\section{Oversikt over nettmaterialets oppbygning}

\begin{tabular}{|c|c|c|}
\hline & Forord & av Nordens sprogråd \\
\hline Kapittel 1 & Introduksjon & Iben Stampe Sletten \\
\hline Kapittel 2 & Nordisk språkhistorie & \\
\hline $2 a$ & Nordiske språk i fortid og nåtid & Arne Torp \\
\hline $2 b$ & Finsk & Kajsa Häkkinen \\
\hline $2 c$ & Samiske språk & Mikael Svonni \\
\hline $2 d$ & Kalaallisut - grønlandsk & Carl Christian Olsen \\
\hline Kapittel 3 & Nåtidens røtter i fortiden & \\
\hline $3 a$ & Om etymologi (dansk) & Zakaris Hansen \\
\hline $3 b$ & Finskan frysbox för germanska ord (svensk) & Birgitta Abrahamsson \\
\hline $3 c$ & Den danske tunge (dansk) & Kristján Árnason \\
\hline Kapittel 4 & Det mangfoldige Norden & \\
\hline $4 a$ & Sidemål nå igjen - fy faen! (norsk) & Gunnar Simonsen \\
\hline $4 b$ & På svenska i Finland (svensk) & Birgitta Abrahamsson \\
\hline $4 c$ & Minoritetsspråk i Norden (svensk) & Marie-Louise Wentzel \\
\hline $4 d$ & De nordiske spesialtegn (norsk) & Arne Torp \\
\hline $4 \mathrm{e}$ & Vet du noe om navn i Norden? (norsk) & Gunnar Simonsen \\
\hline $4 f$ & Den islandske navneskikk (norsk) & Ari Páll Kristinsson \\
\hline Kapittel 5 & Hver mann sitt språk - dialekter i dag & \\
\hline $5 a$ & Får du tala ditt eget språk? (svensk) & Marie-Louise Wentzel \\
\hline $5 b$ & $\begin{array}{l}\text { Dialektar - ei historie om dei pene, } \\
\text { dei korrekte eller dei gale? (norsk) }\end{array}$ & Gunnar Simonsen \\
\hline $5 c$ & Farvel til dialekterne i Danmark (dansk) & Lisbeth Nyborg \\
\hline $5 d$ & Findes der dialekter på Færøerne? (dansk) & Zakaris Hansen \\
\hline $5 e$ & Island - landet uden dialekter? (dansk) & Kristján Árnason \\
\hline Kapittel 6 & Det engelske språk - trussel eller ressurs? & \\
\hline $6 a$ & Om purismen (dansk) & Kristján Árnason \\
\hline $6 b$ & Engelsk tur-retur (dansk) & Lisbeth Nyborg \\
\hline $6 c$ & Om domænetab (dansk) & Lisbeth Nyborg \\
\hline $6 d$ & Have a nice day, hörru! (svensk) & Marie-Louise Wentzel \\
\hline Kapittel 7 & Språk i bevegelse - men hvor går det hen? & \\
\hline $7 a$ & Hvor går språket? (norsk) & Gunnar Simonsen \\
\hline $7 b$ & Ord på väg (svensk) & Marie-Louise Wentzel \\
\hline $7 c$ & Fra runer til sms (dansk) & Lisbeth Nyborg \\
\hline $7 d$ & Globalsprog - nationalsprog - lokalsprog (dansk) & Lisbeth Nyborg \\
\hline $7 e$ & Uddør de nordiske sprog? (dansk) & Lisbeth Nyborg \\
\hline
\end{tabular}




\section{Presentasjon av artikler}

Nordisk språkhistorie (kapittel 2)

I utgivelsens vektigste og mest omfangsrike artikkel: «Nordiske språk i fortid og nåtid» (avsnitt 2a) gjennomgås utviklingen fra et felles urnordisk opphav til de moderne nordiske språk. Det fortelles bl.a. om likheter og oppståtte forskjeller på områder som ordforråd, orddannelse og grammatikk og om tidligere påvirkninger fra bl.a. latin og nedertysk. Dessuten diskuteres det hva to modeller for språkforandringsprosesser, stamtremodellen og bølgemodellen, kan brukes til som språkvitenskapelig verktøy.

Kapittel 2 rommer også de tre artiklene: «Finska» (avsnitt 2b), «Samiske språk» (avsnitt 2c) og «Kalaallisut - grønlandsk» (avsnitt 2d), som introduserer leseren til disse språkenes oppbygning og historie og skisserer den språklige situasjon i de land hvor språkene tales.

Dette kapittel gir svar på spørsmål som: Har alle folk i Norden en gang kunnet forstå hverandre uten videre? Når og hvordan forandret det urnordiske språket seg til de moderne språkene islandsk, færøysk, norsk, svensk og dansk? Og hvorfor er finsk, samisk og grønlandsk ikke nordiske språk?

\section{Nåtidens røtter i fortiden (kapittel 3)}

Dernest følger tre bidrag som fra forskjellig vinkel viser hvordan fortiden er til stede i nåtidens språkbruk.

Avsnitt 3a. Først et avsnitt om etymologi, dvs. vitenskapen om det enkelte ords historie. Etymologi står som ordhistorie i motsetning til den allmenne språkhistorie. Ordhistorie er kulturhistorie som det bl.a. fremgår av de etymologiske forklaringene på ord som ord, stakkel og ben, samt navnene på de nordiske landene. Språkhistorie er både kulturhistorie og knyttet til statenes historie.

Avsnitt 3b. I det neste avsnittet vises det hvordan finsk fungerer som en slags "fryseboks» for en rekke urnordiske ord som er innlånt i det finske språket for mer enn 2000 år siden. Da finsk ikke har vært utsatt for lydforandringer på samme måte som de nordiske språkene, er lånordene mange ganger bevart i sin opprinnelige form, bare tilpasset den finske lydstrukturen.

Avsnitt 3c. En av de store forskjellene mellom nåtiden og middelalderen er at folk fra hele området, fra nordbobygdene på Grønland til Åland og fra Nord-Norge til Jylland, etter alt å dømme har kunnet forstå hverandre og har hatt en felles norm i runespråket. 
I kapitlets siste avsnitt gis en kort introduksjon til «Den danske tunge», som det fellesnordiske kulturspråket ble kalt - og til de forfattere og tidlige «språkvitenskapsmenn» som brukte og utviklet dette språket.

\section{Det mangfoldige Norden (kapittel 4)}

Avsnitt 4a. Det er neppe andre faktorer som har så stor betydning for den kulturelle identiteten som språket. Utviklingen av et norsk skriftspråk var en manifestasjon av landets uavhengighet, men da det ikke helt fortrengte det danske, har man i snart 120 år hatt to offisielle skriftspråk, bokmål og nynorsk - i flere varianter. I kapitlets første avsnitt «Sidemål nå igjen ...» gis en historisk skisse av den særlige norske språksituasjonen, og dens fremtid diskuteres. Er det holdbart at elever skal eksamineres både i hovedmål og sidemål, når det rent lingvistisk er tvilsomt å snakke om to språk? Og kan oppsplittingen tenkes å forsterke sosiale forskjeller?

Avsnitt 4b. I Finland er både finsk og svensk offisielle språk. Hvis man ikke på stående fot vet hvilket språk hhv. finlandssvenske og sverigefinner taler - og hva forskjellen er mellom finner og finlendere - kan man bli klokere i avsnittet «På svenska i Finland». I dag er det ikke lenger obligatorisk å lære begge språk, men hva skjer med tospråkligheten og med den nordiske samhørigheten hvis svensk i stigende grad velges bort?

Avsnitt 4c. Det følgende avsnittet, "Minoritetsspråk i Norden», bidrar til bildet av språklig mangfoldighet med en oversikt over de språkene som er morsmål for deler av befolkningen i de nordiske land uten å være verken hovedspråk, dialekter eller innvandrerspråk. At samisk og romani er beskyttet av den europeiske konvensjonen om regionale språk og minoritetsspråk fra 1998, er kanskje kjent av de fleste, men det gjelder faktisk også språket hos for eksempel kvener i Norge, tornedalsfinner i Sverige, tartarer og gammelrussere i Finland og det tyske mindretallet i Danmark.

Avsnitt 4d. Med et nordisk språk som morsmål kan man bl.a. bli oppmerksom på sin språklige egenart når man sender tekster via et engelskspråklig e-postprogram og resultatet blir en uforståelig «tegnsalat». De fleste språk som bruker det latinske alfabetet, har måttet supplere med spesialtegn. I dette bidraget fortelles historien bak de eksotiske nordiske bokstavene: æ/ä, ø/ö, å, p og ð.

Et særlig fellesnordisk område er personnavn. Mange barn får i dag navn med tusenårige røtter i Norden, men mange andre bølger enn den nordiske har gjennom tidene preget valget av navn og 
deres utforming. Kapitlet avsluttes med to mindre bidrag om navnetradisjonen i hhv. de nordiske land generelt (avsnitt 4e) og den særlige tradisjonen på Island (avsnitt 4f).

\section{Hver mann sitt språk - dialekter i dag (kapittel 5)}

Hvis ikke Kalmarunionen var blitt oppløst på 1500-tallet, ville vi kanskje ha omtalt svensk, norsk, dansk, færøysk og islandsk som skandinaviske dialekter! Men nå har hvert land sitt selvstendige språk - og «dialekter» refererer seg til geografiske varianter innenfor landegrensene, som for eksempel norrlandsk, bornholmsk eller jämtsk.

Avsnitt 5a. Om man forstår hverandre, avhenger ikke bare av språkkunnskaper, men i høy grad også av holdninger. Kapitlets første avsnitt gir et innblikk i hvordan det står til med hensyn til toleransen overfor dialekter i hhv. Finland, Sverige, Norge og Danmark.

Avsnitt 5b. I dag har bruken av dialekt høyst ulik status - og derfor utbredelse $-\mathrm{i}$ de forskjellige nordiske land. Men mange faktorer kan påvirke den videre utviklingen. Muligens vil man som motvekt til globaliseringen se en økt regionalisering, og kunne dialekter så komme til å spille en annen rolle? I avsnittet «Dialektar - ei historie om dei pene, dei korrekte eller dei gale?» diskuteres blant mye annet dialektenes plass i de offentlige medier og de nordiske lands svært forskjellige politikk mht. normering av talespråk. Avsnittets mange spørsmål kan fungere som utgangspunkt for en mengde språkpolitiske diskusjoner.

Avsnitt $5 c$. Polemisk uttrykker man ofte forholdet mellem riksmål og dialekter på følgende måte: «Et språk er en dialekt med en hær og en flåte» (Max Weinreich). I avsnittet «Farvel til dialekterne i Danmark» beskrives situasjonen i Danmark, hvor riksmålets «hær og flåte» har vært spesielt sterk. Som talespråksvariant er det nesten enerådende i det offentlige rom, mens dialekter overveiende brukes i privatsfæren. Prinsipielt mener de fleste som sier noe om det, at det er en rikdom å beherske flere språkvarianter. Hvorfor ser det så ikke ut til å gjelde i praksis?

Avsnitt 5d. Mens dialekter nesten er utdødd i Danmark, trives de tilsynelatende fint i det langt mindre språksamfunnet Færøyene! Kanskje fordi det frem til midten av 1800-tallet ikke fantes et standardisert skriftspråk som diverse dialekter ble samlet og utjevnet i. Uttaleforskjeller er generelt akseptert, men toleransen gjelder ikke i samme grad variasjoner på det grammatiske og det leksikalske 
området - som når en bestemt ordstamme har forskjellig kjønn og derfor også bøyes forskjellig i sør og nord. Les mer i avsnittet: «Findes der dialekter på Færøerne?».

Avsnitt 5e. På Island er tendensen den at regionale uttaleforskjeller utjevnes. Uniformiteten er litt av et mysterium, men skyldes muligens at de fonologiske forandringene siden middelalderen er så små at man stort sett bruker den samme ortografien for nåtidsislandsk som den oldislandske. Sagaspråket fungerer på mange måter som norm for det moderne talespråket, og den språklige konservatismen betyr at nye uttalevarianter lett virker stigmatiserende. Les mer i avsnittet «Island - landet uden dialekter?».

\section{Det engelske språk - trussel eller ressurs? (kapittel 6)}

Språkkontakten mellom de nordiske land har gjennom tidene vært av avgjørende betydning for språkenes utvikling - og ikke alltid har bakgrunnen vært like fredsommelig. I dag er det især kontakten med engelsk som påkaller både negativ og positiv oppmerksomhet, og som utløser mange diskusjoner med mer eller mindre puristisk tilsnitt.

Avsnitt 6a. I kapitlets første avsnitt gis en generell introduksjon til fenomenet purisme, dvs. bestrebelsen for å holde et språk "rent» ved å bruke og anbefale ordformer som oppfattes som naturlige for språket, mens andre varianter betraktes som «urene» og derfor unngås og ofte fordømmes. Man kan således tale om purisme både på det individuelle plan og på et mer overordnet språkpolitisk plan. I artiklen diskuteres holdninger og praksis i det minst puristiske landet, Danmark, og det mest puristiske landet, Island.

Avsnitt 6b. Tidene skifter. I de nordiske språkene er importen av engelske ord stadig stigende og henger især sammen med den amerikanske økonomiske og politiske dominansen etter andre verdenskrig, men en gang var det omvendt. Etter de danske og norske vikingenes inntrengen eksisterte oldnordisk og oldengelsk side om side i flere hundre år og ble etter hvert blandet. Mange av de mest alminnelige ord i moderne engelsk stammer således fra språk som en gang ble talt i det nåværende Tyskland, Danmark og Norge. Det historiske forholdet mellom engelsk og nordisk behandles i avsnittet «Engelsk tur-retur».

Avsnitt 6c. Det er altså ikke et nytt fenomen at man låner fra dem som har makten, og dem man har bruk for å kommunisere med - noe annet er det hvis et helt språk erstattes med et annet! Innlånet av engelske og amerikanske ord på områder som medier, 
handel og teknologi er i dag så massivt at noen mener det helt kan fortrenge nasjonalspråket. Avsnittet handler om dette domenetapet. Kan og skal man gripe inn? Et forbud mot å bruke engelsk er utenkelig, og et påbud om å bruke nasjonalspråket er nytteløst - men hva gjør man så?

Avsnitt 6d. I alle de nordiske land er det de unge som er hovedimportører når det gjelder engelske og amerikanske ord og uttrykk. Mange oppfatter seg nærmest som tospråklige og har ikke noe imot å tilføre sitt hjemlige talespråk en internasjonal touch ved å bruke engelske termer. Men hvorfor er det nå slik at det er smartere å shoppe enn å gå i butikker? Hvorfor lyder oversettelser av for eksempel fast food komiske? Hvorfor skal man overhodet forholde seg til hva big pack eller discman heter i flertall på norsk? Avsnittet «Have a nice day, hörru!» har ikke svaret, men en del flere spørsmål og eksempler.

Språk i bevegelse - men hvor går det hen? (kapittel 7)

Avsnitt $7 a$. Alle levende språk er konstant i bevegelse. Talespråket forandrer seg når folk møter hverandre, lytter, påvirkes og kanskje endrer sin språkbruk noe. På tross av den konserverende innflytelsen fra ordbøker, språknemnd og lærere er også skriftspråket under løpende forandring. Kan man styre denne utviklingen? - og hvorfor prøver man overhodet på det? Kapitlets første avsnitt reiser spørsmålet: «Hvor går språket?» og ser på de forskjellige strategiene som de nordiske land møter endringene med.

Avsnitt $7 b$. Språket forandrer seg stadig hurtigere slik at ordbøker lett blir akterutseilt. En betydning kan overføres fra ett område til et annet, slik en bibetydning snart kan gå over til å være den dominerende. I informasjonssamfunnet skjer forandringene $\mathrm{i}$ et så høyt tempo at det ikke bare er de eldre generasjonene som kan ha vanskelig for å følge med. I avsnittet «Ord på väg» gjennomgås forskjellige typer av betydningsskifter og de forståelsesproblemer de kan medføre.

Avsnitt 7c. Språkets historie omfatter ikke bare ordforrådets, grammatikkens og uttalens utvikling gjennom tidene, men også utviklingen av de materialer og metoder man har brukt til frem- 
stilling, lagring og formidling av språk - under ett kalt medier. Avsnittet «Fra runer til sms» skisserer den betydning som tilkomsten av nye medier har hatt for det språklige uttrykks innhold, form og funksjon. Telegrafen, telefonen, radioen, fjernsynet, datamaskinen og mobiltelefonen har alle påvirket menneskers samværs- og uttrykksformer på overraskende måter. Ingen hadde for eksempel kunnet forutse hva mobiltelefonen ville komme til å bety for barne- og ungdomskulturen - og pussig nok kan SMS-språket sies å ha en del til felles med runeinnskriftene.

Avsnitt 7d. I det følgende avsnittet «Globalsprog - nationalsprog - lokalsprog» reises spørsmålet: Hvordan vil det gå med de nordiske språk og internordisk forståelse i det 21. århundret? Hittil har utviklingen i Norden gått i retning av språklig differensiering, for siden nordboenes felles «danske tunge» har man av nasjonale og politiske grunner distansert seg fra hverandre rent språklig. I dag medfører globaliseringen tilsynelatende en ensretting, med utbredelsen av engelsk som hele verdens språk. Men bildet er ikke entydig. Innføringen av engelsk som lingua franca fremstår akkurat nå som et tap for det nordiske fellesskapet, men kan kanskje $i$ andre omgang bety en demokratisering? Den dagen ville islendinger, færinger, finner, grønlendere og samer som - med unntak av finlandssvenskene - har vært henvist til å delta i fellesskapet på et fremmedspråk, i alle fall være på like fot med dansker, nordmenn og svensker ...

Avsnitt 7e. Frykten for de nordiske språks fremtid retter seg især mot den innflytelse det engelske språket har fått som ungdomsspråk, forretningsspråk og mediespråk, men de nordiske nasjonalspråkene står - ennå? - ikke i akutt fare for å dø ut. Visse samiske språk er imidlertid allerede forsvunnet, og verden over dør språk og kulturer ut, med en fart som aldri før. Ifølge språkforskeres beregninger vil halvdelen av verdens i alt 7300 kjente språk være borte om 100 år. I gjennomsnitt dør det altså ut ett språk hver tiende dag, og med internetts inntog er trusselen om språkdød blitt enda større. Å stille spørsmålet «Uddør de nordiske sprog?», som i dette avsnittet, er derfor relevant. Det er de unges lyst og evne til - og mulighet for - å tale språket som avgjør dets skjebne. Hva er det for en språklig fremtid vi vil ha? Og hvilken plass ønsker vi at de nordiske språkene skal ha fremover?

God fornøyelse!

Oversettelse fra dansk: Gytte Borch 
Nordiske språk i fortid og nåtid

Språklikhet og språkforskjell, språkfamilier og språkslektskap

Folk har til alle tider lagt merke til at ord i forskjellige språk ligna på hverandre, og har gjort seg tanker om hvorfor det er likheter og forskjeller mellom språk. I det kristne Europa antok man gjerne at alle mennesker opprinnelig hadde snakka hebraisk. Det var jo språket i Det gamle testamente, og følgelig måtte også Adam og Eva ha snakka hebraisk i Paradiset. Grunnen til at det seinere ble et mylder av ulike språk, fant man også i Bibelen, nærmere bestemt i kapittel 11 i 1 . Mosebok. Det fortelles her at menneskene ved forente krefter ville bygge et tårn som skulle nå like til himmelen, men dette prosjektet syntes ikke Gud noe særlig om, og derfor greip han inn ved å forvirre språket deres slik at de ikke lenger kunne forstå hverandre, og dermed gav de opp det hele og spredde seg i stedet ut over hele jorda.

\section{Sagnet om Babels tårn}

Dette sagnet skal visstnok være oppstått med bakgrunn i et veldig tårn som hørte til tempelanlegget i byen Babylon ved Eufrat. Navnet Babylon betyr 'Gudenes port', men israelittene tolka det som en form av det hebraiske verbet balal, som betyr forvirre, og der- med ble myten om det såkalte Babelstårn skapt. Uttrykket babelsk forvirring = 'kaos', som fins i mange europeiske språk, henspiller da opphavlig på den tilstanden som oppstod etter at Gud hadde grepet inn og stansa tårnbygginga ved å forvirre menneskenes språk.

Teorien om hebraisk som urspråket er ikke den eneste som har versert i tidligere tider. Den svenske vitenskapsmannen Olof Rudbeck (1630-1702) la i et stort anlagt verk i tre bind med tittelen Atlantica fram en teori om at øyriket Atlantis, som den antikke filosofen 
Platon hevder skulle ha ligget ute i Atlanterhavet før det sank på ei eneste natt, i virkeligheten var Sverige. Men ikke nok med det: Svensk var også urspråket, som både gresk, latin og hebraisk nedstamma fra.

At dette var en minst like fantastisk og usannsynlig teori som sjølve myten om Atlantis, skjønte folk ganske snart. Allerede femti år seinere harsellerte landsmannen Olof von Dalin over Rudbecks fantasterier på denne måten (ortografien er modernisert og sitatet oversatt til norsk):

Sjølve Adams navn er rein svensk: Adam ble jo skapt av jord, av støv. Det er jo Av damm (svensk damm = støv).

Når man fra Avdam tar bort V, så blir det Adam.

Eva er også rein svensk. Da mannen våkna og fikk se sin skjønnhet uten så mye som et fikenblad, er det naturlig at han ble forundra og sa: He! Hva? Og av de to orda blir jo straks: Heva?

Teorien om at hebraisk var opphavet til alle andre språk, var ikke lett å bevise - og den var jo heller ikke riktig, skulle det vise seg. Men før man fikk en vitenskapelig metode som kunne påvise om eller hvordan språk var beslekta, var det heller ikke mulig å motbevise slike teorier som at hebraisk eller svensk skulle være det urspråket som alle verdens språk hadde utvikla seg fra.

En slik metode fikk man imidlertid på begynnelsen av 1800-tallet med oppdagelsen av det vi kaller genetisk språkslektskap. Med den såkalte historisk-komparative språkvitenskapen fikk man et eksakt redskap til å fastslå $h v a$ likheter mellom språk kommer av. De kan nemlig skyldes enten:

1. allmenne forhold i den første språkinnlæringsprosessen, som når ord av typen mamma og pappa gjerne heter omtrent det samme over hele verden, eller

2. såkalt lån, som når det opprinnelig greske ordet demokrati eller det arabiske ordet alkohol også fins over store deler av verden, eller

3. at språk som i dag kan være ganske forskjellige, har utvikla seg gjennom ørsmå sprang over mange generasjoner fra ett felles opphav.

Bare i det siste tilfellet er det snakk om genetisk språkslektskap. 


\section{Den historisk komparative metoden}

Dersom et bestemt år skulle utropes til å markere startpunktet for historisk språkforsking, slik vi kjenner den i dag, måtte det være året 1786. Da holdt nemlig den britiske orientalisten Sir William Jones et foredrag for The Royal Asiatic Society i Calcutta i India, der han bl.a. omtalte det gamle indiske språket sanskrit på følgende måte:

The Sanskrit language, whatever its antiquity, is of a wonderful structure; more perfect than the Greek, more copious than the Latin, and more exquisitely refined than either; yet bearing to both of them a strong affinity, both in the roots of verbs and forms of grammar, than could possibly have been produced by accident; so strong, indeed, that no philologer could examine the Sanskrit, Greek and Latin, without believing them to have sprung from some common source, which, perhaps, no longer exists.

Den tanken Jones kaster fram her, er altså at ei rekke språk som alt for et par tusen år siden var nokså ulike, en gang $\mathrm{i}$ ei enda fjernere fortid hadde utvikla seg fra ett felles urspråk, som «perhaps, no longer exists», som han uttrykker det - han kunne nok godt ha sløyfa reservasjonen «perhaps», men ellers var ideen hans helt riktig, som det snart skulle vise seg.

Foredraget ble lagt merke til også i Europa, og snart var språkforskere i gang med å prøve å finne ut hvordan den sammenhengen som Jones hadde antyda, kunne bevises ved strenge vitenskapelige metoder. Sentrale navn her er tyskerne Franz Bopp (17911867) og Jacob Grimm (1785-1863), og deres og andres innsats la grunnlaget for all seinere utforsking av indoeuropeiske språk. Også her i Norden hadde vi en forsker med et internasjonalt ry fullt på høyde med de to nevnte tyskerne, nemlig dansken Rasmus Rask (1787-1832), som i løpet av sitt korte liv utførte grunnleggende undersøkelser innafor indoeuropeisk, ikke minst innafor nordiske språk, men han interesserte seg også for språk utenfor den indoeuropeiske familien, bl.a. finsk og samisk.

I samme periode som den historisk-komparative metoden ble utvikla, skjedde det ei rivende utvikling innafor naturvitenskapene - ikke minst innafor biologien, der Darwins utviklingslære markerer en avgjørende milepæl. Biologer og språkfolk begynte dermed omtrent samtidig å ta i bruk den såkalte stamtremodellen for å vise 


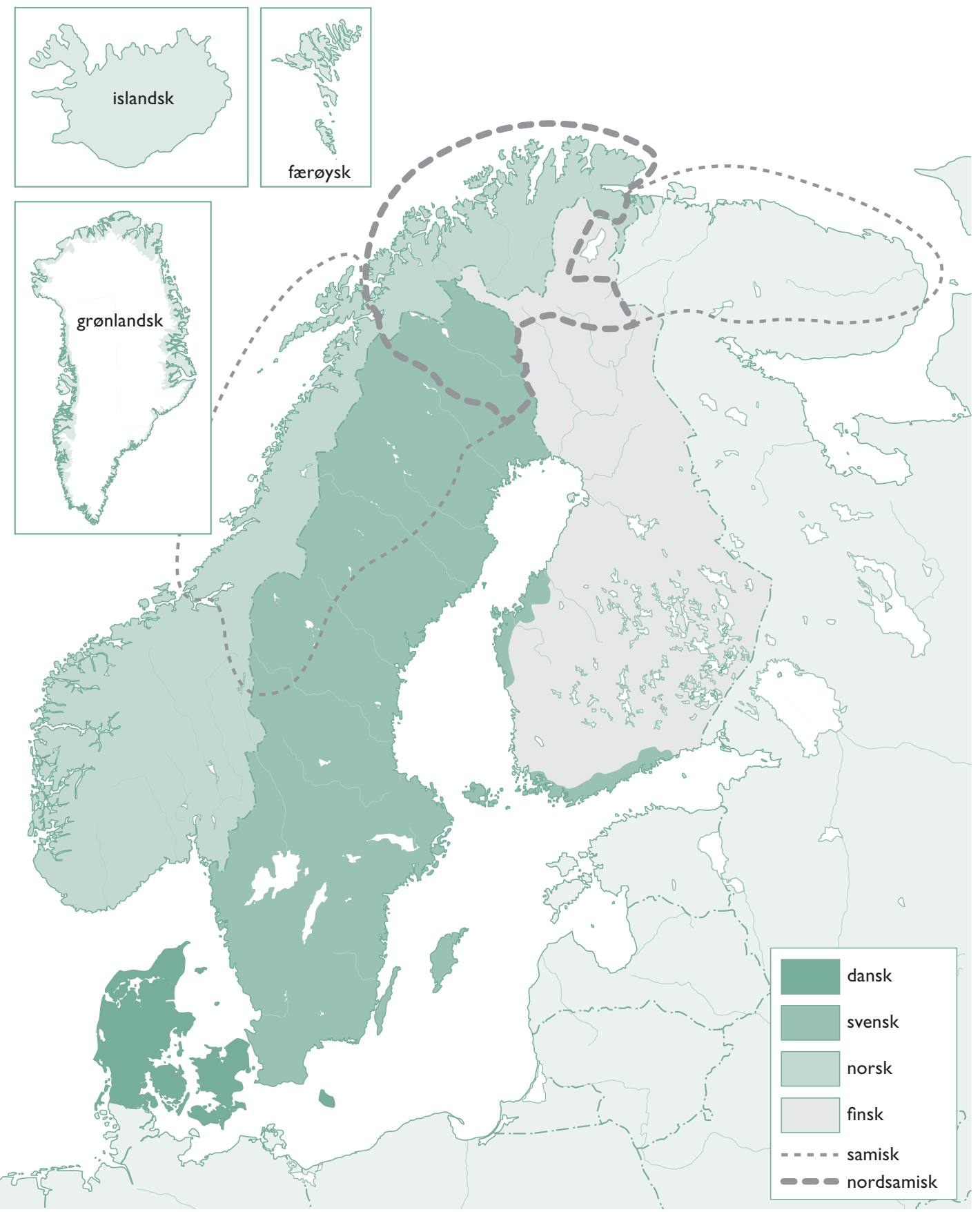

Figur 1: Norden - geografisk område og tradisjonelle språk 
hvordan både nålevende organismer og moderne språk hadde utvikla seg fra tidligere former. Disse stamtrærne har i motsetning til normale trær i skogen vanligvis rota øverst, mens greinene vokser nedover (se f.eks. figur 4 nedenfor).

\section{Språka i Norden: Tre familier - mange språk}

I Norden finner vi både nært beslekta språk og språk som hører til helt forskjellige familier. Det politisk-geografiske området vi kaller Norden, strekker seg helt fra Grønland i vest over Island og Færøyene og til Finland i øst - med Danmark, Norge og Sverige midt imellom. Innafor dette store området snakkes det språk som dels har felles historisk opphav, dels ikke (se figur 1).

Fra slutten av 1700-tallet har språkforskere visst at språk forandrer seg gjennom tida på en slik måte at det går an å sette opp såkalte lover for hvordan lydene på ett steg i språkutviklinga svarer til tidligere og seinere stadier av det samme språket. Lydlovene er et av de viktigste redskapene i den historisk-komparative metoden, for ved hjelp af disse lovene har man klart å etablere en rekke språkfamilier, dvs. grupper av språk som har utvikla seg fra et felles opphav. Hvordan disse lovene virker i praksis, skal vi se nærmere på seinere.

Til å begynne med skal vi bare se hvordan lydlig likhet kan brukes til å etablere ulike språkfamilier. Vi skal da sammenligne de fem første tallorda i fire språk fra den indoeuropeiske språkfamilien, nemlig norsk, tysk, engelsk og fransk, og så de samme tallorda i samisk, finsk og ungarsk, som hører til den uralske familien.

\begin{tabular}{lllllll}
\hline \multicolumn{2}{l}{ indoeuropeisk } & \multicolumn{5}{c}{ uralsk } \\
\hline norsk & tysk & engelsk & fransk & samisk & finsk & ungarsk \\
\hline en/ein & eins & one & un & okta & yksi & egy \\
to & zwei & two & deux & guokte & kaksi & kettö \\
tre & drei & three & trois & golbma & kolme & három \\
fire & vier & four & quatre & njeallje & neljä & négy \\
fem & fünf & five & cinq & vihtta & viisi & öt \\
\hline
\end{tabular}

Figur 2: De fem første tallorda i en del indoeuropeiske og uralske språk 
Som vi ser, ligner talla ganske mye på hverandre i de tre første av disse språka, og det skyldes at de hører til den samme greinen på det indoeuropiske "treet», nemlig den germanske. Fransk hører derimot til den romanske greinen, som har utvikla seg fra latin, som er et såkalt italisk språk. De franske talla ligner derfor mye mindre på talla $i$ de tre første kolonnene, men fremdeles kan vi ane en viss likhet. De uralske talla er derimot helt annerledes enn de indoeuropeiske, men oppviser til gjengjeld innbyrdes likhet. Blant de uralske språka ser vi at samisk og finsk må høre til en annen grein enn ungarsk.

Når det dreier seg om helt ulike språkfamilier, ville det derimot vært både uventa og usannsynlig at tallorda skulle ligne på hverandre, og som vi ser, gjør de da heller ikke det. Indoeuropeisk og uralsk er altså to forskjellige språkfamilier nettopp fordi man ikke ved hjelp av lydlover kan sannsynliggiøre et felles opphav.

Innafor en og samme språkfamilie kan vi derimot bruke lydlovene til å etablere forskjellige undergrupper. Som vi ser av disse eksemplene, kan de nålevende medlemmene i en språkfamilie ofte være ganske ulike, akkurat som fjerne slektninger er det i den biologiske verden. Dersom de hører til samme familie, har de imidlertid utvikla seg av ett og samme «urspråk». Dette urspråket har vi ofte ikke noe konkret vitnesbyrd om i form av skriftlige eller andre minnesmerker, akkurat som vi heller ikke vet særlig mye om hvordan våre forfedre i ei fjern fortid så ut.

I språkvitenskapen kan forskerne imidlertid med stor grad av sannsynlighet rekonstruere slike ukjente «urspråk» ved hjelp av den historisk-komparative metoden. Denne metoden går bl.a. ut på å sammenligne både nålevende språk og særlig de eldste formene vi har konkrete vitnesbyrd om i form av skriftlig overlevering. Innafor Norden finner vi i dag språk som hører til tre ulike familier, og forholdet mellom de enkelte medlemmene i hver familie kan framstilles skjematisk som i figur 3 .

Der er altså viktig å skille mellom nordiske språk - som er en felles betegnelse for den nordgermanske undergruppa av den indoeuropeiske familien: dansk, svensk, norsk, færøysk og islandsk - og språk i Norden, som også omfatter språk fra både den uralske språkfamilien: samisk og finsk - og fra den eskimoisk-aleutiske familien: grønlandsk.

Den indoeuropeiske språkfamilien skal vi seinere si mye mer om, men bare et par ord først om de to andre språkfamiliene. 


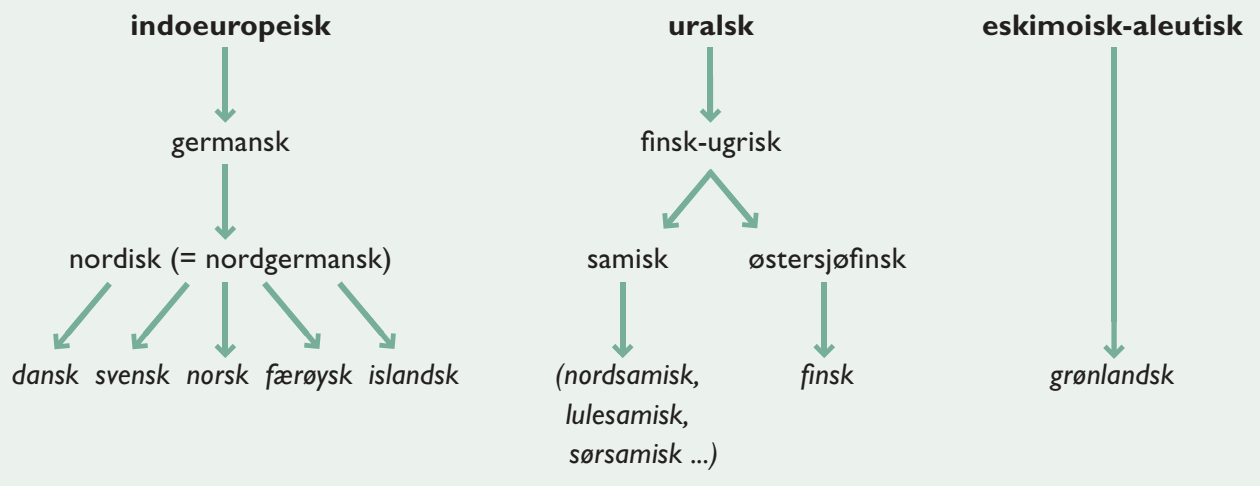

Figur 3: Språkfamiliene og språka i Norden

Grønlandsk tilhører den eskimoisk-aleutiske familien, for grønlenderne eller inuitt, som de kaller seg sjøl, har sine språklige slektninger vestover - i Nord-Amerika - over Nord-Canada og Alaska til øygruppa Aleutene sør for Beringhavet (se artikkelen om grønlandsk).

Familienavnet uralsk forteller at språkforskerne antar at finnene og samene har sine språklige røtter i nærheten av Uralfjella i Russland. Den uralske familien omfatter foruten diverse små språkgrupper i Russland også et stort europeisk språk, nemlig ungarsk, samt finskens både språklig og geografisk nære nabo estisk. Faktisk er finsk og estisk så nær beslekta at de er delvis innbyrdes forståelige. Men forståeligheten går stort sett bare den ene vegen - esterne er nemlig mye flinkere til å forstå finsk enn finnene til å forstå estisk! (Se også artikkelen om finsk.)

Det gjelder også mange andre steder i verden at folk i et mindre språksamfunn som oftest er mye flinkere til å forstå det «store» språket enn omvendt. Dette ser vi bl.a. også i forholdet mellom små og store nordiske språk: De aller flinkeste er de som tilhører det minste nordiske språksamfunnet, nemlig de ca. 45000 færøyingene. De forstår faktisk veldig bra alle nordiske språk - medregna litt islandsk. På jumboplassen havner derimot ofte svenskene, som utgjør det største nordiske språksamfunnet - nærmere 9 millioner: Undersøkelser har vist at svensker forstår dårligere både dansk og norsk enn dansker og nordmenn forstår svensk.

Samisk kan i språklig forstand knapt regnes som bare ett språk, ettersom de mest ulike samiske «dialektene» er like forskjellige som 
f.eks. skandinavisk og tysk, dvs. at de ikke er innbyrdes forståelige (se artikkelen om samisk). Dette innebærer at samer fra ulike dialektområder ofte ikke kan snakke samisk med hverandre, men må i stedet bruke et felles fremmedspråk, i praksis blir det da flertallsmålet i vedkommende land (norsk, svensk, finsk eller russisk). Et slikt felles fremmedspråk som brukes av folk med ulike morsmål når de skal snakke sammen, kaller vi et lingua franca.

\section{Lingua franca}

Lingua franca brukes i dag om et hvilket som helst språk som folk med forskjellige morsmål bruker som felles kommunikasjonsmiddel uten at noen av dem har det som morsmål. I vår tid er det først og fremst engelsk som fyller denne funksjonen over store deler av verden, men f.eks. i det som tidligere var Sovjetunionen, er det oftest russisk, og i Afrika kan det være diverse gamle europeiske kolonispråk (engelsk, fransk, portugisisk), men også mer lokale afrikanske språk (f.eks. swahili i Øst-Afrika).

Reint bokstavelig betyr lingua franca imidlertid 'fransk språk', men denne betegnelsen refererte opprinnelig ikke til det vi i dag kjenner som fransk, men til et såkalt pidginspråk, dvs. et forenkla hjelpespråk som ingen har som morsmål, men som bare blir brukt når folk uten felles morsmål snakker sammen. Dette opprinnelige lingua franca var da et slikt pidginspråk med svært forenkla grammatikk, men basert på ord fra diverse romanske språk (særlig provençalsk, italiensk og spansk) og som ble brukt i handelssamkvem rundt Middelhavet i mange hundre år, fra mellomalderen og fram til 1800 tallet. I våre dager fins det mange pidginspråk i andre deler av verden, oftest basert på ord fra europeiske kolonispråk (særlig engelsk og fransk).

Tidligere fantes det er pidginspråk $\mathrm{i}$ Skandinavia også, nemlig russenorsk, som ble brukt i den såkalte pomorhandelen, som foregikk mellom russere og nordmenn i Nord-Norge fra 1700-tallet og fram til første verdenskrig. Orda i russenorsk var dels henta fra russisk, dels fra norsk, men også fra diverse andre europeiske språk (engelsk, tysk, nederlandsk). Pomor er et russisk ord som kan oversettes med «kystboere» eller «folk som bor ved havet»».

Henvisninger til internettadresser der du kan lese mer om lingua franca, pomorhandelen og russenorsk, finner du på side 74 . 
Det er jo ikke særlig overraskende at språk som ikke har noe påviselig felles opphav, er svært forskjellige. Men også innafor de enkelte språkfamiliene er det ofte store forskjeller mellom de ymse «familiemedlemmene». Dette gjelder i høy grad innafor den uralske familien, og ikke mindre innafor den indoeuropeiske familien, som vi nå skal se litt nærmere på.

\section{Den indoeuropeiske språkfamilien}

Den første som tegna stamtrær for den indoeuropeiske familien, var tyskeren August Schleicher (1821-1868). Stamtreet hans så slik ut:

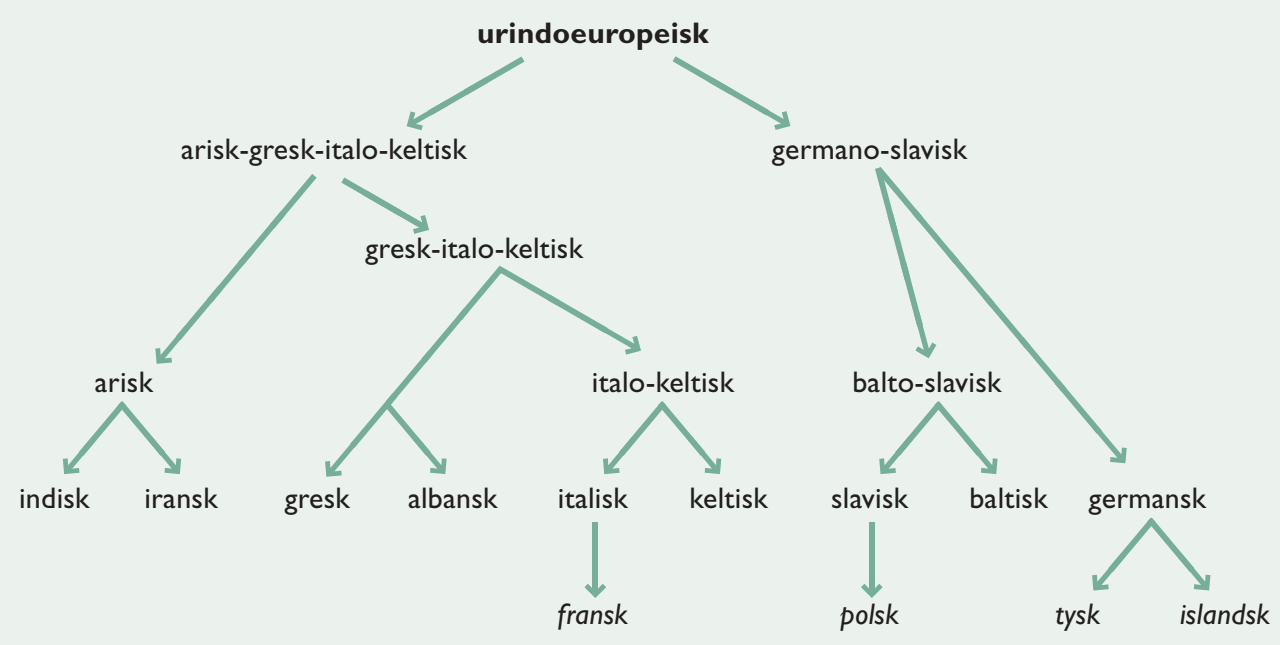

Figur 4: Schleichers indoeuropeiske stamtre. De fire moderne språka som står nederst $\mathrm{i}$ «treet» med kursiv skrift, er ikke med hos Schleicher; de er tilføyd her. Hvorfor akkurat disse språka er valgt ut som eksempler, vil bli klart nedenfor.

Dette skal oppfattes slik at Schleicher tenkte seg at urindoeuropeisk først delte seg i to «greiner» - «arisk-gresk-italo-keltisk» og "germanoslavisk» - deretter delte hver av disse gruppene seg videre i to osv. Hver av disse delingene var da et resultat av at det hadde oppstått dialektforskjeller innafor et opprinnelig enhetlig indoeuropisk 
urspråk. Slike dialektforskjeller oppstår i særlig grad etter at forskjellige grupper av den opprinnelige folkestammen har forlatt «urhjemmet» (hvor det nå enn kan ha vært; det vet ingen sikkert) og har slått seg ned på vidt forskjellige steder.

\section{Det indoeuropeiske urspråket}

Opphavet til de indoeuropeiske språka ligger fremdeles $i$ et halvmørke, både når det gjelder tid og sted. Den vanligste antagelsen går ut på at alle indoeuropeiske språk går tilbake på ei urform som var ett enhetlig språk for ca. 5-6000 år siden, og ble snakka av ei folkegruppe som bodde et eller annet sted nord eller sør for Svartehavet - her er ikke forskerne enige.

Den første gruppa som forlot «urhjemmet», var sannsynligvis de som seinere er kjent som hettittene, et gammelt kulturfolk i det østlige Lilleasia. Noen forskere mener at denne utvandringa skjedde for minst 4000 år siden. Seinere har så de forskjellige gruppene - indoiranere, slavere, keltere, germanere - vandra i ulike retninger, slik at vi etter hvert fikk indoeuropeiske språk over hele Europa og en stor del av Asia. Ved kolonisering i nyere tid har indoeuropeiske språk som engelsk, spansk, fransk og portugisisk spredd seg til alle verdens kontinenter.

Såkalte geolekter - dvs. geografiske talemålsforskjeller, eller det vi til daglig kaller dialekter - oppstår som regel på grunn av fysiske hindringer av et eller annet slag. Det som skaper skiller mellom dialekter, er først og fremst stor geografisk avstand eller naturformasjoner, som høye fjell og ugjennomtrengelige skoger eller sumpområder, som vanskeliggjør all slags daglig kommunikasjon. Det er først med våre dagers massemedier - ikke minst de elektroniske at vi for første gang i historia er i stand til å kommunisere med hvem som helst uten hensyn til fysiske hindringer eller avstand. Utvandring til fjerne områder ville dermed i eldre tid uvegerlig føre til at det oppstod dialektforskjeller, som over tid stadig vokste seg større og etter hvert effektivt blokkerte all språklig kommunikasjon mellom de forskjellige utvandrergruppene.

Dersom vi oppfatter «treet» i figur 4 som ei framstilling av faktiske likheter og forskjeller mellom ulike språk i dag, vil en trulig finne ut at modellen stemmer ganske bra: Språk som hører til sam- 


\section{Språkutvikling: Feil på feil i det uendelige ...}

Når ei folkegruppe som opphavlig snakka det samme språket, deler seg opp i flere grupper som ikke lenger har kontakt med hverandre, vil det etter hvert få store konsekvenser for språket. Og hovedgrunnen til at det er slik, er ganske enkelt det faktum at folk ikke lever evig. Dermed må språket så å si skapes på nytt av hver generasjon - det vil si - bygges opp i småbarnsalderen på grunnlag av det språket barnet hører i omgivelsene. Det er jo da slett ikke merkverdig at det oppstår små forskjeller mellom det språket den eldre generasjonen snakker, og det språket barna «konstruerer». Sett fra den eldre generasjonens synspunkt snakker da de unge «feil», men dersom mange nok gjør den samme «feilen», vil etter hvert «feilen» bli ny norm.

Som et konkret eksempel kan vi nevne ordet tak, som i dag kan bety to helt forskjellige ting: Vi kan snakke om tak på et hus, og vi kan «ta et tak», dvs. gripe fast i noe. Her hadde man i eldre nordisk to ord som ble uttalt forskjellig: Om å gripe fast i noe sa man tak, men om «hustak» sa man pak, med den samme lyden fremst i ordet som th-lyden i engelsk thing. I disse orda har alle de skandinaviske språka for lengst mista th-lyden, og det skjedde for en stor del alt i mellomalderen. Her har vi altså eksempel på en «uttalefeil» som har slått an over hele Skandinavia. På Island har de derimot fremdeles beholdt forskjellen mellom $p$ og $t$, så der heter det fremdeles tak (å gripe noe) og pak (hustak).

Men også på Island har språket endra seg fra eldre tid - om enn ikke på langt nær så mye som i Skandinavia. Et eksempel på dette har vi ved vokalen $y$, som er blitt til $i$ på islandsk, slik at islendingene uttaler presens av verba biter og flyter som rimord: bitur og flitur (derimot skrives de ulikt: bítur og flýtur).Vi kan dermed konstatere at folk i Skandinavia har gjort visse «feil» som ikke har slått an på Island, mens islendingene har gjort andre «feil» som ikke er vanlige i Skandinavia.

Poenget er altså at ikke alle gjør de samme «feila», sjøl om språket til å begynne med var likt: Dersom folk lever atskilt lenge nok, vil det nemlig uvegerlig oppstå forskjeller, fordi folk i ulike miljøer gjør forskjellige «feil».

me grein, er mer like enn språk som hører til forskjellige greiner. Fransk, polsk og tysk er svært ulike, trass i at Tyskland er nabo både med Frankrike og Polen. Når disse tre språka likevel er så forskjellige, skyldes det at greinene de hører til, skilte lag for veldig lenge siden. De har derfor hatt lang tid på å utvikle særtrekka sine. 
Tysk og islandsk er heller ikke innbyrdes forståelige språk, men ligner hverandre likevel mye mer enn språket i de tre nabolanda, trass i stor geografisk avstand mellom Tyskland og Island. Når tysk og islandsk er såpass like, må det ha sammenheng med slektskapet: Begge er germanske språk.

\section{Stamtremodell og nordiske språk}

Når man bruker stamtremodellen på nordiske språk, får man derimot et resultat som ikke stemmer like godt med det vi vanligvis oppfatter som vesentlige forskjeller og likheter mellom de ulike språka.

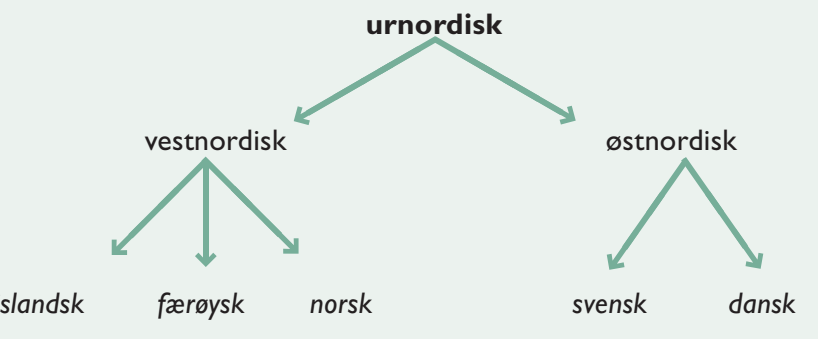

Figur 5: Inndeling av nordiske språk etter stamtremodellen

Dersom vi «leser» dette treet på samme måte som vi gjorde med det indoeuropeiske treet $\mathrm{i}$ forrige avsnitt, skulle vi vente at norsk ligna islandsk og færøysk mer enn svensk og dansk. Dette vet i alle fall alle nordmenn ikke stemmer; nordmenn forstår dansk og svensk rimelig bra, svensk til og med nesten like bra som morsmålet, mens både færøysk og islandsk er fremmedspråk. I dette tilfellet stemmer det altså ikke at språk som ligger nær hverandre i "greinverket», også ligner hverandre i den forstand at de f.eks. er innbyrdes forståelige - det gjelder nemlig ikke de tre «kvistene» (islandsk, faroysk, norsk) på den vestnordiske greinen. Samtidig er de to kvistene (svensk, dansk) på den østnordiske greinen både innbyrdes forståelige med hverandre og med den ene av de vestnordiske kvistene (norsk). Her kan vi altså ikke bruke stamtremodellen som vegviser til å finne ut likheter og forskjeller mellom de moderne språkformene, for det er neppe noe fornuftig menneske som vil hevde at norsk ligner mer på islandsk og færøysk enn på svensk og dansk. 
Hvorfor man likevel i det hele tatt snakker om «østnordisk» mot «vestnordisk», skal vi si mer om seinere. Det fins nemlig visse historiske årsaker til at det fører galt av sted å bruke stamtremodellen til å vise likheter og forskjeller mellom de nålevende nordiske språka. Men først skal vi se litt nærmere på den større gruppa som de nordiske språka hører til innafor den indoeuropeiske familien, nemlig de germanske språka.

\section{Den germanske språkgruppa}

Germanske språk er i dag spredd over det meste av kloden, først og fremst på grunn av kolonisering i nyere tid, dvs. i løpet av de siste vel 300 åra. Trass i at disse språka opprinnelig hører heime i Europa, er det noen av dem som stort sett snakkes utenfor Europa - det gjelder ikke minst det såkalte verdensspråket engelsk.

Faktisk er det ett germansk språk som bare snakkes i det sørlige Afrika, nemlig afrikaans. Dette er først og fremst morsmålet til de såkalte boerne, som kom fra Nederland til dette området fra midten av 1600-tallet.

Jiddisch, de europeiske jødenes språk, er i hovedsak basert på tysk, men har også en god del elementer fra hebraisk. Før andre verdenskrig var det mange flere som snakka det. I slutten av 1920åra regna man med ca. 7 millioner i Europa og i 1930-åra mellom 1 og 1,5 millioner i USA. Spørsmålstegna i tabellen viser at det mangler opplysninger om antallet.

\begin{tabular}{|c|c|c|}
\hline språk & $\begin{array}{r}\text { morsmålsbrukere } \\
\text { i Europa }\end{array}$ & $\begin{array}{r}\text { morsmålsbrukere } \\
\text { utenfor Europa }\end{array}$ \\
\hline engelsk & 60000000 & 400000000 \\
\hline tysk & 98000000 & ? \\
\hline nederlandsk & 21000000 & ? \\
\hline svensk & 9000000 & ? \\
\hline afrikaans & $?$ & 6000000 \\
\hline dansk & 5300000 & ? \\
\hline norsk & 4500000 & ? \\
\hline frisisk & 400000 & ? \\
\hline jiddisch & $?$ & 400000 \\
\hline islandsk & 280000 & ? \\
\hline færøysk & 55000 & ? \\
\hline
\end{tabular}

Figur 6: Germanske språk - antall morsmålsbrukere 
Hvordan disse elleve språka har utvikla seg fra det opprinnelige indoeuropeiske urspråket, kan man beskrive ved hjelp av de metodene som brukes i den historisk-komparative språkvitenskapen. Og her arbeider man som nevnt ut fra prinsippet om at lydendringer ikke er tilfeldige, men tvert imot styrt av ganske bestemte lydlover.

\section{Den germanske lydforskyvinga}

Det viktigste kjennetegnet som skiller den germanske språkgruppa ut fra resten av den indoeuropeiske språkfamilien, er en lydlov som kalles den germanske lydforskyvinga. Det er denne forskyvinga som er ansvarlig for at orda far og fe begynner på $f i$ alle nordiske språk, mens f.eks. de tilsvarende orda i latin begynner på p: pater og pecu (uttalt / peku/, med $u$ som i dansk eller tysk).

Som vi ser, er de moderne nordiske orda far og fe temmelig ulike de latinske orda pater og pecu. Men dersom vi går bakover i språkhistoria, ser vi at de tilsvarende germanske orda ligner stadig mer på de latinske. For tusen år siden - altså på norrønt - het det f.eks. fađir og fé, og går vi enda fem hundre eller tusen år bakover - til urnordisk eller urgermansk - het det fader og fehu, og da er avstanden til pater og pecu som vi ser, straks mye mindre.

Legg likevel merke til at også disse eldste germanske formene begynner på $f$; i motsatt fall hadde det vist at de ikke var germanske, men at de måtte være lån fra en annen grein innafor den indoeuropeiske familien - eller fra en helt annen språkfamilie.

\section{Norrønt og urnordisk}

Navnet norrønt brukes vanligvis om språket både i Norge og på Island fra 900-tallet og framover mot ca. 1350. Den gangen var språket $\mathrm{i}$ disse to landa nesten det samme, for islendingene er opprinnelig norske emigranter spesielt fra Vestlandet, og det samme gjelder også færøyingene. Moderne islandsk og færøysk har derfor også visse påfallende likhetstrekk med dialektene iVest-Norge, noe som kanskje delvis kommer av dette felles opphavet, mens andre mener at det også kan skyldes kontakt med Norge i seinere tid.

På norrønt språk fins det en stor litteratur, som først og fremst er islendingenes verk - den islandske mellomalderlitteraturen på morsmålet er langt større og mer betydelig enn på alle andre nordiske språk til sammen. De fleste litterære verkene er bevart i handskrifter som for det meste går tilbake til 1200-tallet.

Dansk og svensk språk var allerede på denne tida en del forskjellig fra 
norrønt, dvs. at dialektoppdelinga

innafor de nordiske språka var allerede

i gang - spesielt kunne en merke at dansk begynte å skille seg ut.

Urnordisk er den eldste formen av germanske språk vi har konkrete vitnesbyrd om i form av skriftlige minnesmerker. Urnordisk er bare overlevert i innskrifter med et spesielt germansk alfabet vi kaller runer. De fleste runetegna minner om de latinske bokstavene vi bruker i dag, og det viser at den eller de som skapte runene, kjente til ett eller flere av de alfabetene som var brukt i middelhavslanda. De eldste innskriftene stammer fra ca. år 200 e. Kr., og fram til ca. år 500 var språket i hele Skandinavia urnordisk - og trolig nokså ensarta. Den mest berømte av alle runeinnskrifter stod på et drikkehorn av gull som ble funnet i jorda i 1734 ved landsbyen Gallehus i Sønderjylland.
I oversettelse lyder teksten slik:

Jeg Legjest fra Holt (ev. Holtes sønn) laga hornet.

Hvor nært dette språket ligger urgermansk, kan vi se av denne sammenlignende oppstillinga, der gullhorninnskriften er «oversatt» både til rekonstruert urgermansk (merket * foran innskriften betyr at vi ikke har direkte kilder for dette språktrinnet), til det samtidige germanske språket gotisk, som vi kjenner fra en bibeloversettelse, og til det vesentlig yngre norrøne språket.

URGERMANSK (ca. 200 f. Kr.)

*Ek Hlewagastiz hultijaz hurnan tawidōn

URNORDISK (400-tallet)

Ek HlewagastiR holtijaR horna tawido

GOTISK (300-tallet)

Ik Hliugasts hulteis haúrn tawida

NORRøNT (fra ca. 1000)

Ek Hlégæstr hyltir horn táða

\section{Arveord, lånord og importord}

Ord som «følger lydlovene», slik vi så i eksemplene far og fe, regner vi med har eksistert i språket fra eldgammal tid, og derfor kaller vi dem arveord.

Den germanske lydforskyvinga har likevel ikke ramma alle ord som svarer til latinske ord som begynner med $p$. I moderne germanske språk har vi f.eks. ei rekke ord som begynner med patereller patr-, f.eks. paternalisme og patriark. Alle disse har også noe visst «faderlig» over seg, og det er ikke tilfeldig. Dette er såkalte lånord eller importord, som er avleda fra den latinske (eller greske) forma pater.

På tilsvarende måte er adjektivet pekunicer avleda av det latinske ordet pecu. I det gamle Roma var nemlig pecu (= husdyr, storfe) et 
vanlig verdimål, jf. at løsøre på norrønt ble kalt liggjanda fé, mens husdyr var ganganda fé.

Importord kan vi altså ikke bruke til å påvise slektskap mellom språk. I så fall ville vi ut fra "nordiske» ord som sauna og sisu eller anorakk og kajakk måtte slutte at nordiske språk var i slekt med finsk eller grønlandsk, men det er jo slett ikke tilfellet. Det importorda derimot viser, er at det har vært kontakt mellom brukerne av eksport- og importspråka.

\section{Arveord og importord}

Arveorda i språket hører gjerne til det vi regner som det sentrale ordforrådet, slik som tallord (se ovenfor) og betegnelser for de nærmeste biologiske slektningene, jf. far, mor, søster og bror. Men allerede ved litt fjernere slektninger finner vi ofte importord; jf. onkel, tante, nevø og niese, som alle kommer fra fransk; i motsetning til; nordiske arveord (sammensetninger) som farbror/morbror, faster/moster (< fars/mors søster) og søskenbarn.

Importorda deles ofte i såkalte lånord og fremmedord. Kriteriet for denne inndelinga er graden av «fremmedhet»: Dersom et ord er så integrert i språket at det bare er språkhistorikere som kan se eller høre at ordet opprinnelig er importert, kalles det gjerne lånord. Dette gjelder f.eks. skandinaviske ord som opprinnelig stammer fra det germanske «søsterspråket» nedertysk - det er bare de som kjenner språkhistoria, som kan vite at ord som prate, snakke og språk er nedertyske importord, mens synonymene tale, tunge og mål er nordiske arveord - dersom vi ikke kjente språkhistoria, kunne det like gjerne vært omvendt.

Når de nedertyske orda er så lite fremmedarta, skyldes nok det både at de har vært brukt i skandinaviske språk ganske lenge - de aller fleste kom inn i mellomalderen - og at nedertysk er et nærbeslekta germansk søsterspråk. Derfor var det heller ikke store forandringer som skulle til før de kunne gli ubemerka inn - de tre orda ovenfor heter f.eks. praten, snakken og sprake på nedertysk.

Derimot er det et visst fremmed preg over ord som konversere og lingvistikk, som består av elementer som ikke uten videre kan forstås. Arveord og lånord på mer enn to stavelser er derimot gjerne sammensatt av forståelige elementer - jf. sam-tale og språk-viten-skap. Ord som konversere og lingvistikk kaller derfor mange fremmedord. Det fremmede preget skyldes oftest at de er lånt fra fjernere språk - de to sistnevnte stammer f.eks. fra latin. Men fremmedheten kan også skyldes at orda er nyimporterte - ferske engelske importord som knowhow og goodwill røper seg lett 
både gjennom skrivemåte og uttale.

Derimot er det neppe andre enn språkfolk som vet at et eldre importord som kjeks stammer fra engelsk cakes - her er tilpassinga til norsk språkstruktur total både når det gjelder skrivemåte og uttale. Kjeks må dermed klart regnes som lånord og ikke fremmedord.

\section{Skandinavia: Ulike språk eller bare dialekter?}

Et geografisk område der talespråket varierer på en slik måte at naboer alltid kan snakke med hverandre ved hjelp av morsmålet, og slik at ingen av partene behøver spesiell trening eller opplæring for å forstå den andre, kalles et dialektkontinuum. Nedenfor ser du hva vi kan tenke oss folk fra tre større skandinaviske byer vil svare dersom de blir spurt om hvor de bor - her vil ikke oppstå forståelsesproblemer selv om det ikke er tale om nabobyer. Merk at skrivemåten gjengir uttalen; den viser altså ikke det normale skriftspråket.

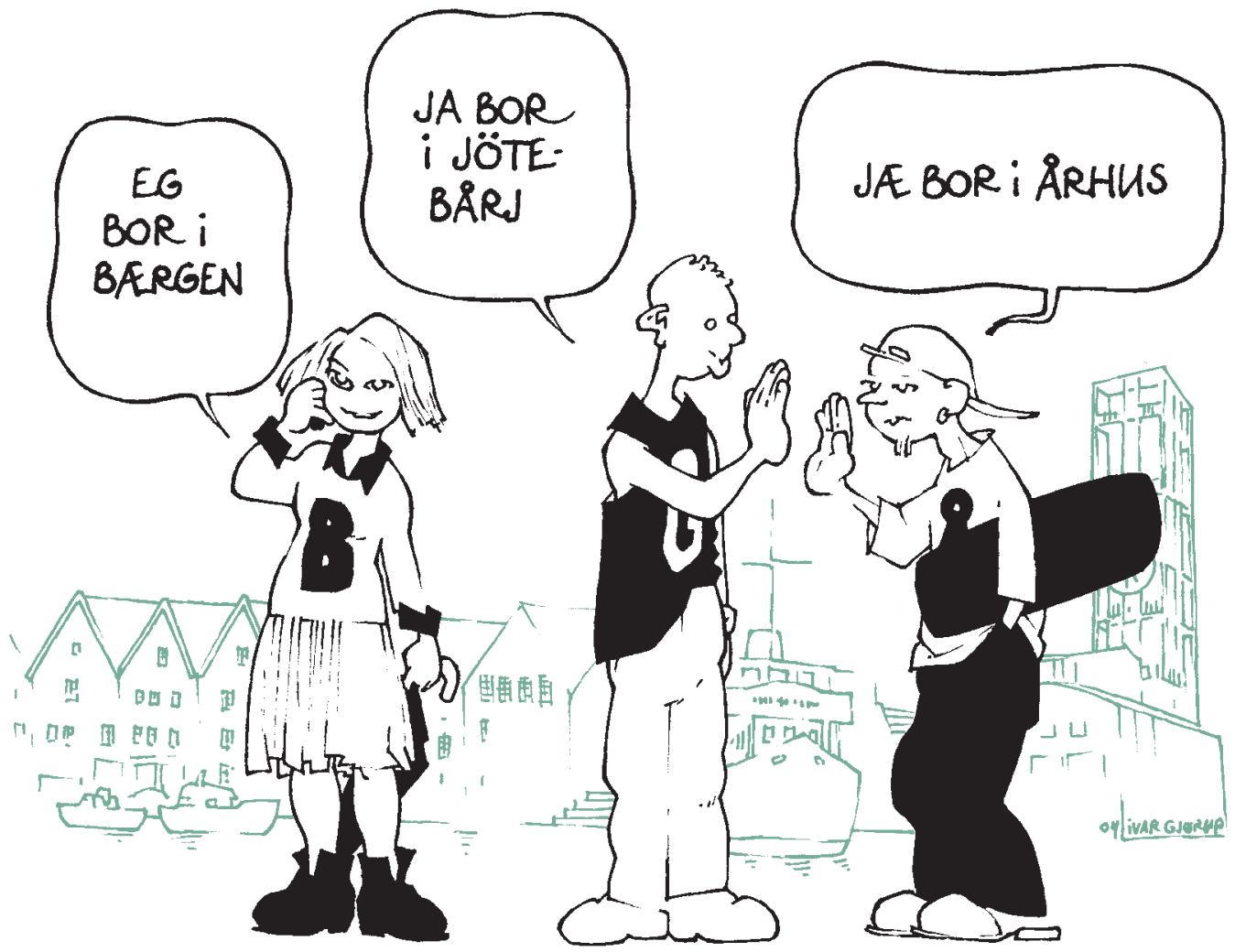


De lokale dialektene i Skandinavia utgjør et slikt dialektkontinuum. Om en reiser sørover fra Finnmark i Norge gjennom hele Norge, Sverige og Danmark til Sønderjylland eller vestover fra Österbotten i Finland gjennom Norrland i Sverige til vestkysten av Norge, vil nabodialektene hele tida være innbyrdes forståelige.

\section{Avstandsspråk}

Om f.eks. en bonde fra Älvdalen i Sverige og en fisker fra Vest-Jylland i Danmark skulle snakke sammen på sine respektive lokale dialekter, ville det derimot oppstå store problemer. Fordi älvdalsmål og vestjysk opplagt ikke er innbyrdes forståelige, kan de regnes som to forskjellige avstandsspråk. Trass i dette hører disse to talemåla likevel til samme dialektkontinuum, fordi det ikke fins noe skarpt brudd i de lokale dialektene mellom Dalarna og Vest-Jylland; det er hele tida tale om en glidende overgang.

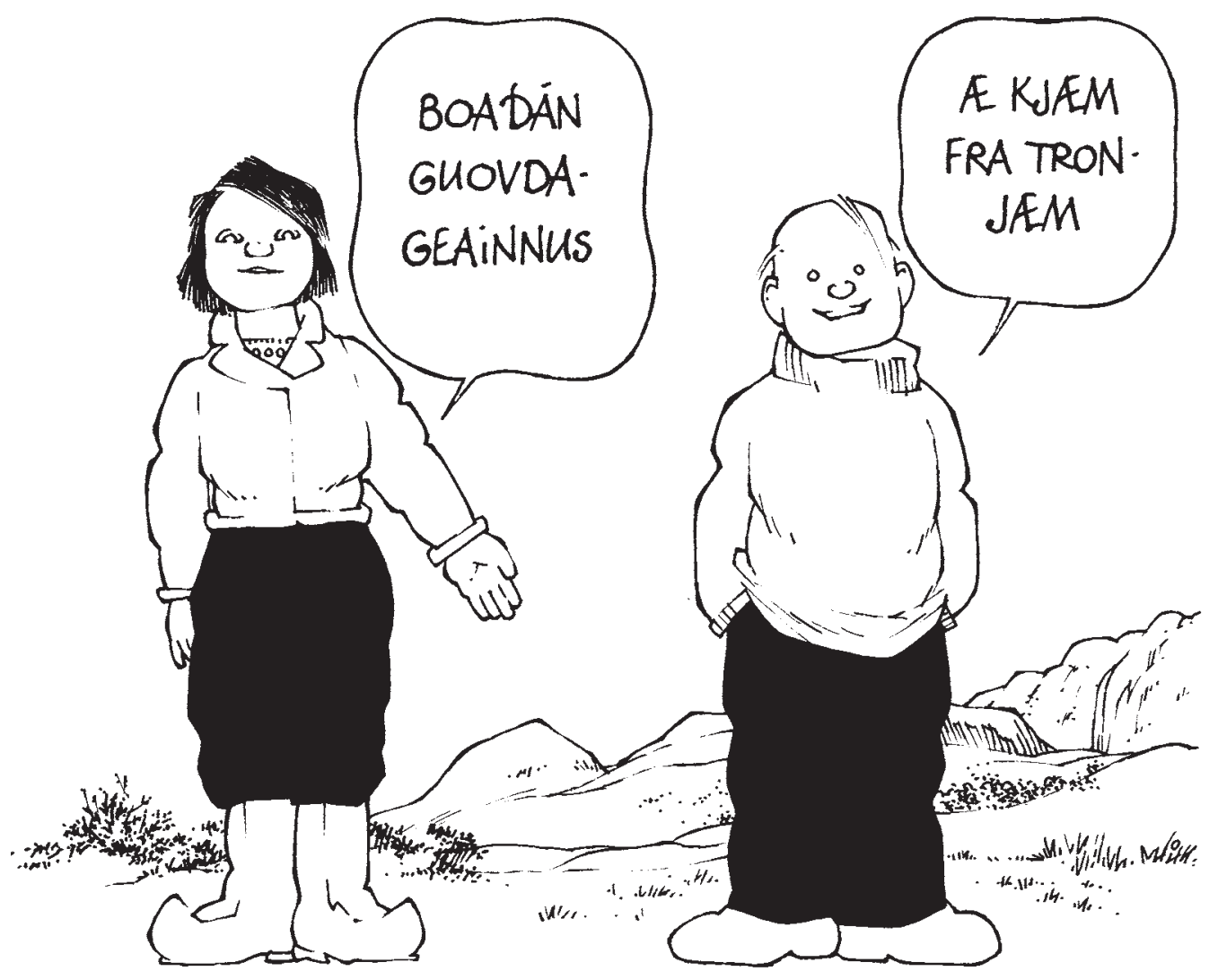




\section{Avstandsspråk}

Vil du høre hvordan älvdalsk og jysk lyder, kan du finne språkprøver på disse adressene:

swedia.ling.umu.se

www.statsbiblioteket.dk

I grenseområdet mellom Sverige og Norge er det nærmest en politisk sak å avgjøre om en dialekt skal regnes som svensk eller norsk - på visse steder har jo faktisk grensa også blitt flytta i tidligere hundreår - f.eks. var Jämtland og Härjedalen norsk område før 1645. Derimot er det svært lett å avgjøre om en nordmann snakker samisk eller norsk, eller om en finlender snakker finsk eller svensk. Her fins det nemlig ingen gradvis overgang, her er det enten-eller.

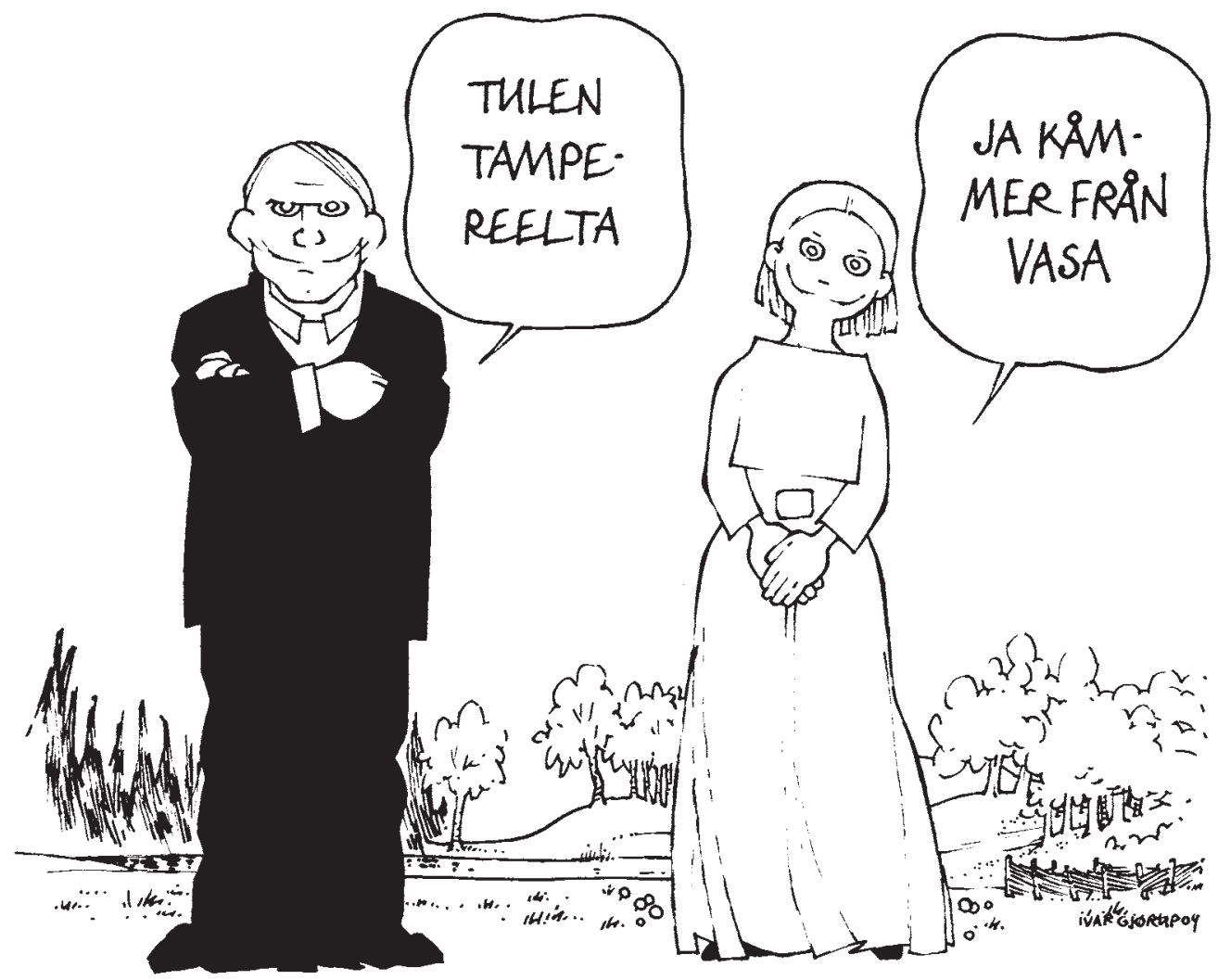


Heller ikke i det tysk-danske grenseområdet er det særlig tvil om hvilket språk en person snakker, sjøl om alternativene her kan være flere og den reint språklige avstanden er mye mindre. Her står nemlig tre ulike germanske dialekter mot hverandre: sønderjysk, plattysk (= nedertysk) og nordfrisisk. Dessuten er det i dag mange som snakker både riksdansk og høgtysk i grenseregionen. Trass i at den språklige avstanden er mye mindre enn mellom finsk og svensk, er riksdansk og høgtysk heller ikke umiddelbart innbyrdes forståelige. I alle disse tilfellene er det altså snakk om ulike avstandsspråk, ettersom heller ikke naboene forstår de andres språk, med mindre de har lært det.

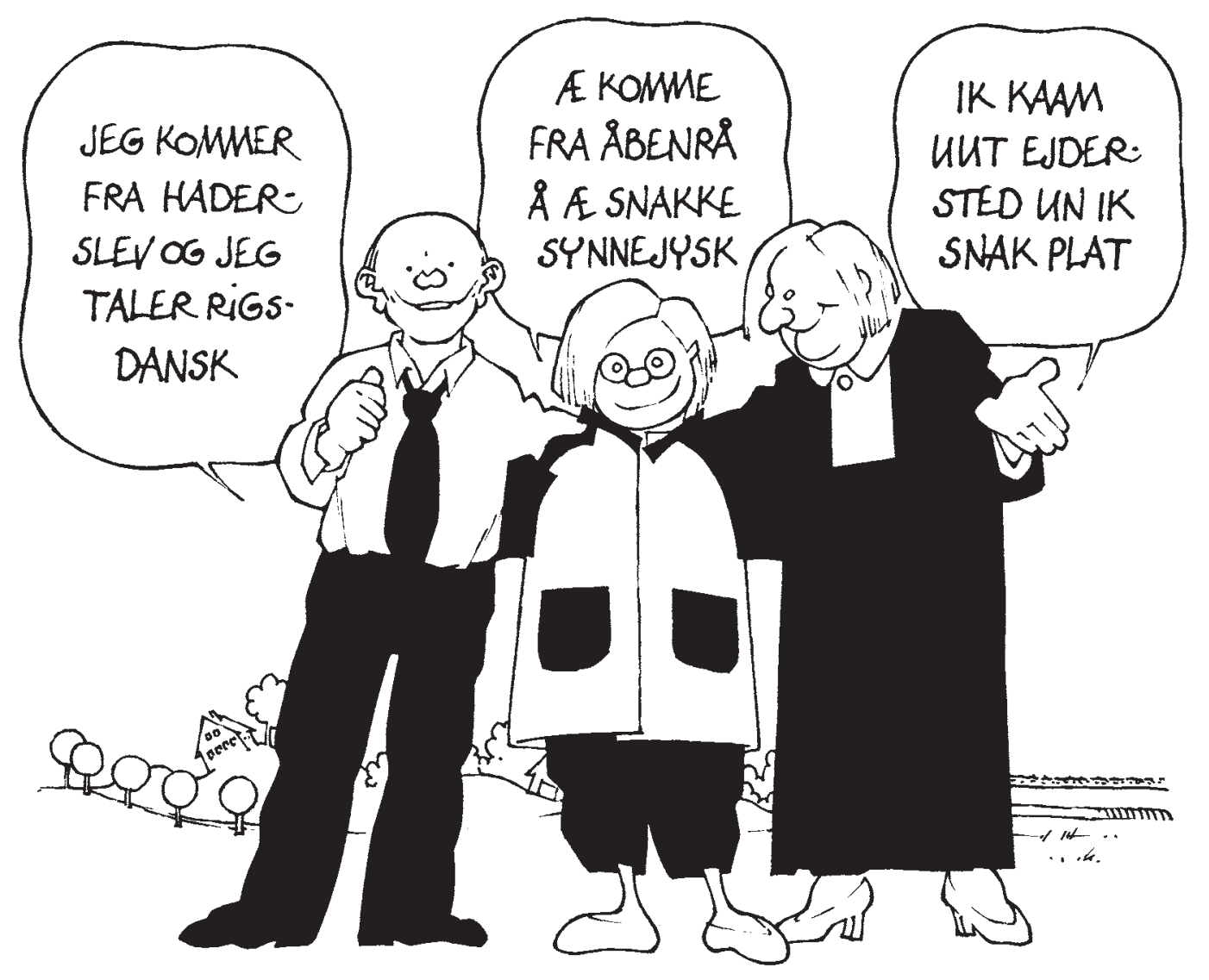




\section{Om sønderjysk, plattysk og nordfrisisk}

Det fins ikke noen allment anerkjent standardisert skrivemåte for de tre dialektene. På adressene nedenfor kan du lese mer om hver av dialektene og bl.a. se at der er mange forskjellige ideer om hvordan uttalen skal gjengis.

plattysk: www.lowlands-I.net

www.rostra.dk

frisisk: www.lowlands-I.net

sønderjysk: www.dialekt.dk

www.jyskordbog.dk
Den frisisktalende personen nedenfor kommer således fra en by som på høgtysk heter Niebüll (formen Naibel er såkalt Algemeyn Nedersaksisch Schryvwyse, dvs. «Allmenn nedersaksisk skrivemåte»).

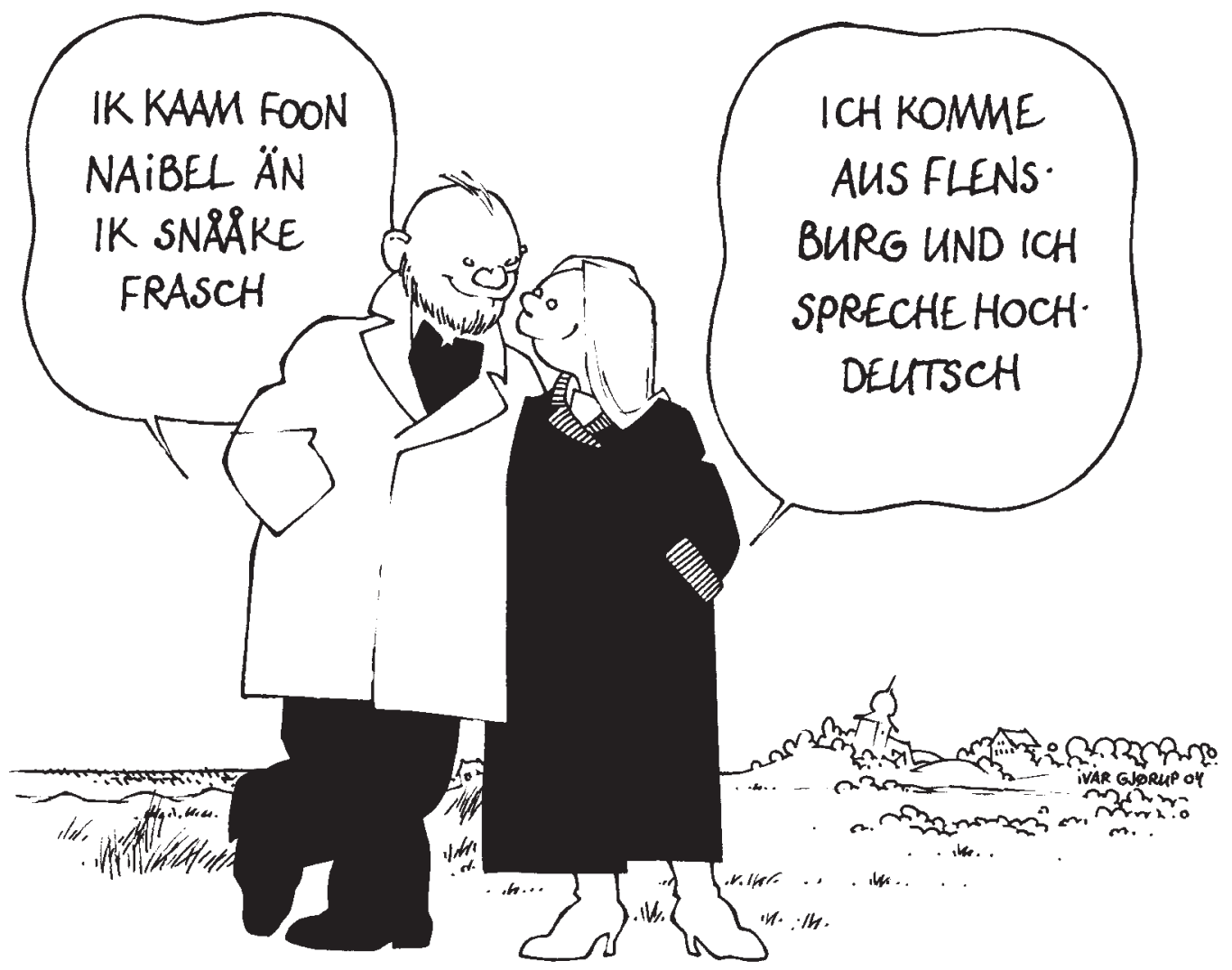




\section{Standardspråk}

Hittil har vi omtalt det skandinaviske dialektkontinuumet som om det ikke fantes noe annet talemål i Skandinavia enn de lokale dialektene. Alle er sjølsagt klar over at det slett ikke er tilfellet - snarere tvert imot. I dag er det i praksis i veldig høy grad de såkalte standardtalemåla som dominerer, i alle fall i Danmark og Sverige.

Et standardtalemål er et talemål som er standardisert, dvs. at det fins normer for hvordan talemålet skal være. Et standardtalemål er dessuten i våre samfunn nært knytta til et skriftspråk. Både standardtalemål og skriftspråk er relativt enhetlige over et større område, f.eks. i en nasjonalstat. På begge disse punktene skiller standardspråket seg fra dialektene, som varierer lokalt og vanligvis bare eksisterer som talespråk. Reglene for korrekt språkbruk eksisterer bare i hjernen på dem som bruker vedkommende dialekt.

Vanligvis har et standardtalemål mye høyere prestisje enn lokale dialekter. Dette har primært sosiale årsaker, i og med at både standardtalemålet og skriftspråket er basert på talemålet til en politisk og økonomisk elite, oftest knytta til hovedstaden. Men på grunn av denne sosiale prestisjen oppstår det også en idé om at standardspråket er det eneste «korrekte» språket, og at dialektene i en eller annen forstand er feil. Når man snakker om dansk og svensk språk, er det nok derfor helst standardspråket i tale og skrift man tenker på; danske og svenske dialekter er liksom noe annet.

I Danmark og Sverige er derfor de tradisjonelle dialektene i sterk tilbakegang i de fleste områder, slik at det helst bare er eldre mennesker på landsbygda som snakker det dialektforskere ville kalle «ekte dialekt». Dessuten vil de aller fleste både dansker og svensker nærmest automatisk legge bort en eventuell lokal dialekt når de snakker med folk fra andre deler av landet. 
I Norge er situasjonen noe annerledes. Dette skyldes blant annet at man i Norge har to utgaver av skriftspråket, såkalt bokmål og nynorsk, noe som vi skal gå mer inn på seinere. Men den spesielle norske språksituasjonen viser seg også ved at de lokale dialektene er vesentlig mer brukt i Norge enn i nabolanda. Formelt ytrer den norske dialekttoleransen seg f.eks. ved at norske lærere ikke har lov til å rette på elevenes talemål - elevene har med andre ord full rett til å bruke sitt naturlige talespråk også i timene, uansett hvilken dialekt det dreier seg om. Og i praksis ser vi det samme, når lokale dialekter i Norge også kan brukes i situasjoner der standardtalemål ville vært en selvfølge i nabolanda - f.eks. når folkevalgte holder innlegg i landets nasjonalforsamling Stortinget. I muntlige massemedier som radio og fjernsyn blir det også ofte snakka dialekt; de eneste som plikter å holde seg til bokmål eller nynorsk, er medarbeiderne i det statlige kringkastingsselskapet NRK når de bruker manuskript, derimot ikke i friere samtaleprogrammer.

\section{Dialektkontinua og standardspråk innafor det germanske språkområdet}

Dersom vi holder oss til Europa, finner vi disse dialektkontinua innafor det germanske språkområdet:
1. kontinentalgermansk
Østerrike, Sveits, Tyskland, Nord-Belgia og det meste av Nederland
2. frisisk den nederlandske provinsen Friesland
3. engelsk det meste av Storbritannia
4. skandinavisk det meste av Danmark, Sverige og Norge
5. færøysk Færøyene
6. islandsk Island

Figur 7: Germanske dialektkontinua i Europa 

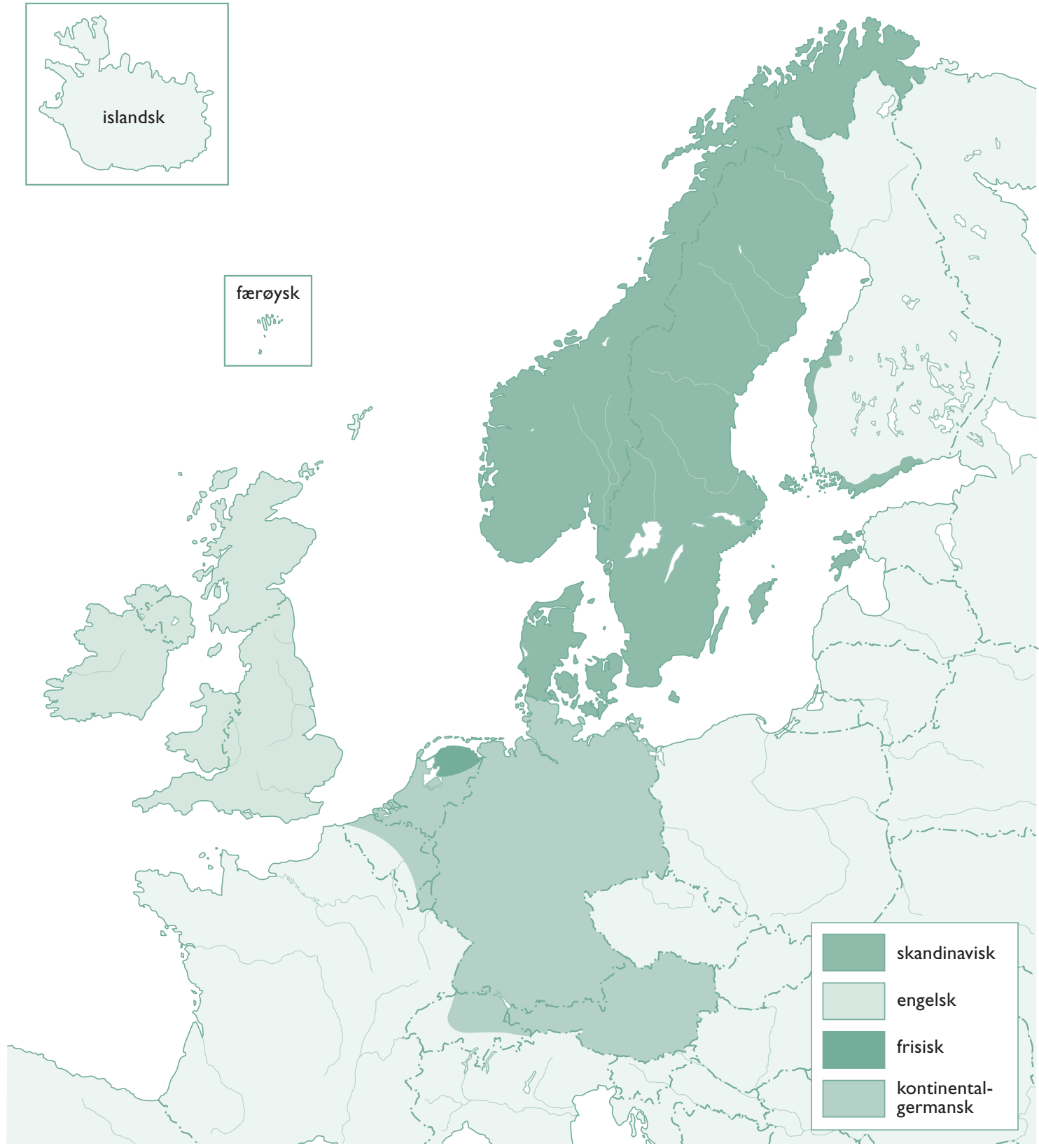

Figur 8: Kart over germanske dialektkontinua i Europa 
Innafor hvert dialektkontinuum finner vi opp til fire forskjellige standardspråk. Av figur 9 nedenfor ser vi at kontinentalgermansk og skandinavisk eksisterer bare som dialektkontinuum, ikke som standardspråk. Innafor hvert av disse to kontinua finner vi flere standardspråk, mens vi bare har ett standardspråk for hvert av de fire øvrige (frisisk, engelsk, færøysk og islandsk).

1. kontinentalgermansk

a. tysk

b. nederlandsk

2. frisisk

3. engelsk

4. skandinavisk

a. svensk

b. dansk

c. norsk (bokmål og nynorsk)

5. færøysk

6. islandsk

Figur 9: Germanske standardspråk i Europa

\section{Tre eller fem språk?}

Når det gjelder skandinavisk, kan det diskuteres om en skal regne med tre standardspråk (dansk, norsk og svensk) eller fire (norsk = bokmål og nynorsk) eventuelt fem (svensk = finlandssvensk og sverigesvensk).

På språklig grunnlag er det ikke grunn til å regne svensken i Sverige som forskjellig fra svensken i Finland, ettersom skriftspråket er det samme; både skrivemåte, ordformer og bøyinger er felles. Uttalen er ganske visst temmelig forskjellig, men den varierer også innafor Sverige; de fleste skandinaver greier uten videre å høre forskjell på f.eks. en skåning og en stockholmer, sjøl om begge snakker svensk riksspråk. Svensk bør altså regnes som ett språk, $i$ alle fall i skrift, trass $i$ at det brukes i mer enn ett land.

Med bokmål og nynorsk er det omvendt: De brukes begge bare i Norge, men her er det til gjengjeld tydelig forskjell. Bare se på disse to setningene, som betyr nøyaktig det samme, mens alle orda er litt forskjellige i de to versjonene:

- Jeg vet ikke hva de fortalte dere (bokmål)

- Eg veit ikkje kva dei fortalde dykk (nynorsk) 
Trass i disse klare forskjellene regnes bokmål og nynorsk likevel gjerne som ett språk, «norsk». I Norge kaller man derimot bokmål og nynorsk ulike målformer av norsk, da nynorsk og bokmål jo faktisk er forskjellige på en hel del punkter. Reint språklig er altså nynorsk og bokmål forskjellige, trass i at begge brukes i det samme landet, mens finlandssvensk og «sverigesvensk» faktisk er identiske (i alle fall i skrift), trass $i$ at de brukes $i$ hvert sitt land.

\section{Hvorfor bokmål og nynorsk?}

Grunnen til at man har to norske målformer i Norge, mens man klarer seg med bare én form av både dansk og svensk, er både historisk og politisk. Bokmål er historisk sett ei «fornorska» utgave av det danske skriftspråket som var i bruk i Norge fra den gangen landet var i politisk union med Danmark (fra ca. 1400 til 1814).

Nynorsk er derimot et nytt skriftspråk som ble etablert ca. 1850 på grunnlag av de norske bygdedialektene, som et «nasjonalt» alternativ til dansken. Mannen som skapte dette nye skriftspråket etter å ha reist rundt i det meste av Norge og undersøkt «Almuesproget», som man gjerne kalte det den gangen, var den geniale sjøllærte språkforskeren Ivar Aasen (1813-1896). Bokmål er derfor veldig likt dansk - i skrift, ikke i uttale! - mens nynorsken har visse trekk felles med færøysk og islandsk. Færøyene og Island ble nemlig i si tid - dvs. for ca. tusen år siden - bosatt av folk som for det meste kom fra Vestlandet i Norge, og nynorsken ligner derfor aller mest dialektene på Vestlandet. I denne landsdelen er også nynorsk det skriftlige hovedmålet i skolene på landsbygda, mens bokmål er hovedmål $i$ byene på Vestlandet og stort sett overalt ellers i Norge.

\section{Moderne nordiske språk}

Dersom vi tar utgangspunkt i de standardspråka som fins innafor nordisk, får vi i alt fem eller seks: Fem, dersom «norsk» skal regnes som ett språk, og seks dersom de to norske såkalte målformene (bokmål og nynorsk) hver for seg skal regnes som et eget språk. Om vi derimot regner norsk som ett språk og bruker innbyrdes forståelighet som inndelingsgrunnlag, vil det være naturlig å gruppere moderne nordiske språk slik: 


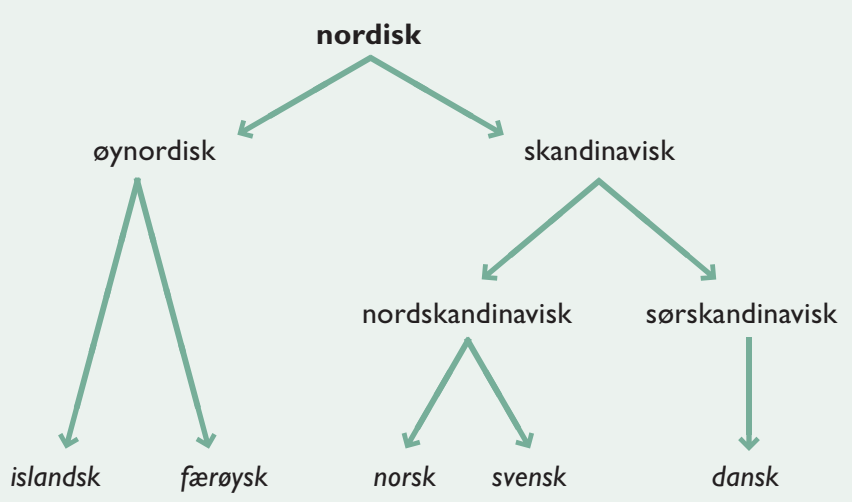

Figur 10: Inndeling av nordiske språk i dag basert på innbyrdes forståelighet

Dette «treet» illustrerer bl.a. at skillet mellom skandinavisk på den ene sida og øynordisk på den andre er det primære skillet i dag. Øynordisk og skandinavisk er nemlig stort sett innbyrdes uforståelige både i muntlig og skriftlig form. De øynordiske språka, islandsk og færøysk, kan på si side kanskje regnes som innbyrdes forståelige i skrift, men neppe i tale, sjøl om færøyingene forstår islandsk bedre enn islendingene færøysk. I motsetning til dette har vi så de skandinaviske språka, som langt på veg er innbyrdes forståelige både i skrift og tale.

Videre illustrerer diagrammet at forskjellen mellom dansk (= sørskandinavisk) på den ene sida og norsk/svensk (= nordskandinavisk) på den andre er større enn den innbyrdes forskjellen mellom norsk og svensk. Det er viktig å være klar over at diagrammet i dette tilfellet primært viser situasjonen i talespråket, ettersom det først og fremst er den avvikende danske uttalen som skaper dette skillet. Dersom vi går etter skriftbildet, ligner nemlig norsk bokmål atskillig mer på dansk enn på svensk. Norsk uttale har derimot alltid ligna mye mer på svensk enn på dansk.

Sterkt forenkla kan vi dermed si at nordmennene på grunn av geografien (nære naboer på den skandinaviske halvøya) har det meste av uttalen felles med svenskene. På grunn av historia (politisk union og felles skriftspråk i over fire hundre år) har de derimot en stor del av ordforrådet og skrivemaiten felles med danskene. 


\section{Stamtremodellen om igjen}

Som vi har sett tidligere, ser stamtremodellen - dvs. inndelinga av de nordiske språk etter genetisk slektskap (figur 5) - helt annerledes ut enn den inndelinga etter innbyrdes forstålighet mellom de moderne språka som ble presentert i forrige avsnitt (figur 10). Her er den igjen:

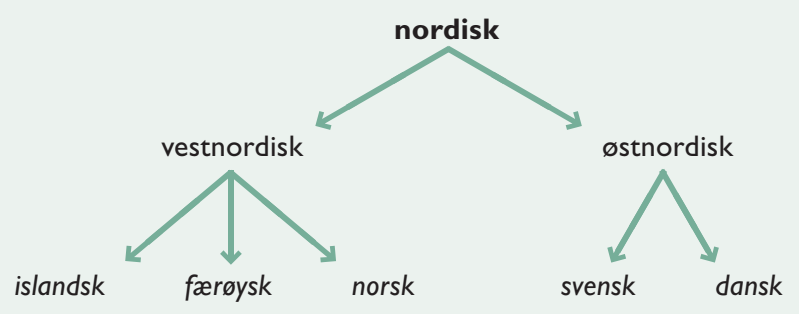

Figur 5 (gjentatt): Inndeling av nordiske språk etter stamtremodellen

At stamtremodellen ikke alltid gir like «rimelige» resultater - på den måten at der kan være en motsetning mellom hvordan forskjellige språk oppleves, og slektskapet mellom dem i språkhistorisk forstand - er noe man lenge har vært klar over. Alt på slutten av 1800-tallet lanserte tyskeren Johannes Schmidt (1843-1901) som alternativ til stamtreet den såkalte bølgemodellen. Han bruker et bilde av bølger som sprer seg som ringer over ei vannflate når man kaster en stein uti.

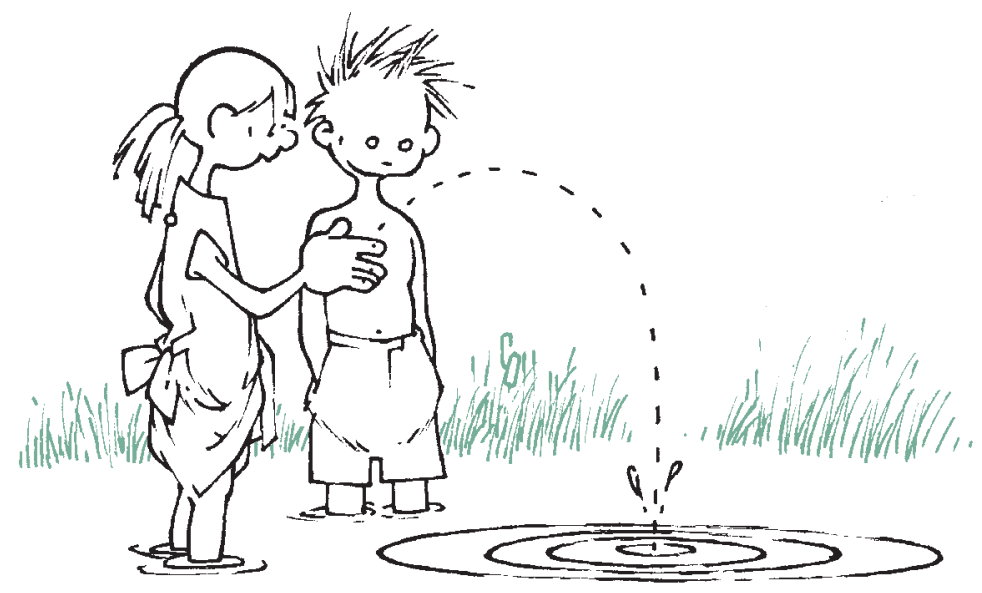


Bølgebevegelsen representerer da ei språklig forandring - en innovasjon - som sprer seg gjennom et språksamfunn. Når forskjellige steiner havner på forskjellige steder i vannet, vil bølgene etter hvert danne et innvikla mønster av sirkler som skjærer hverandre på ymse måter.

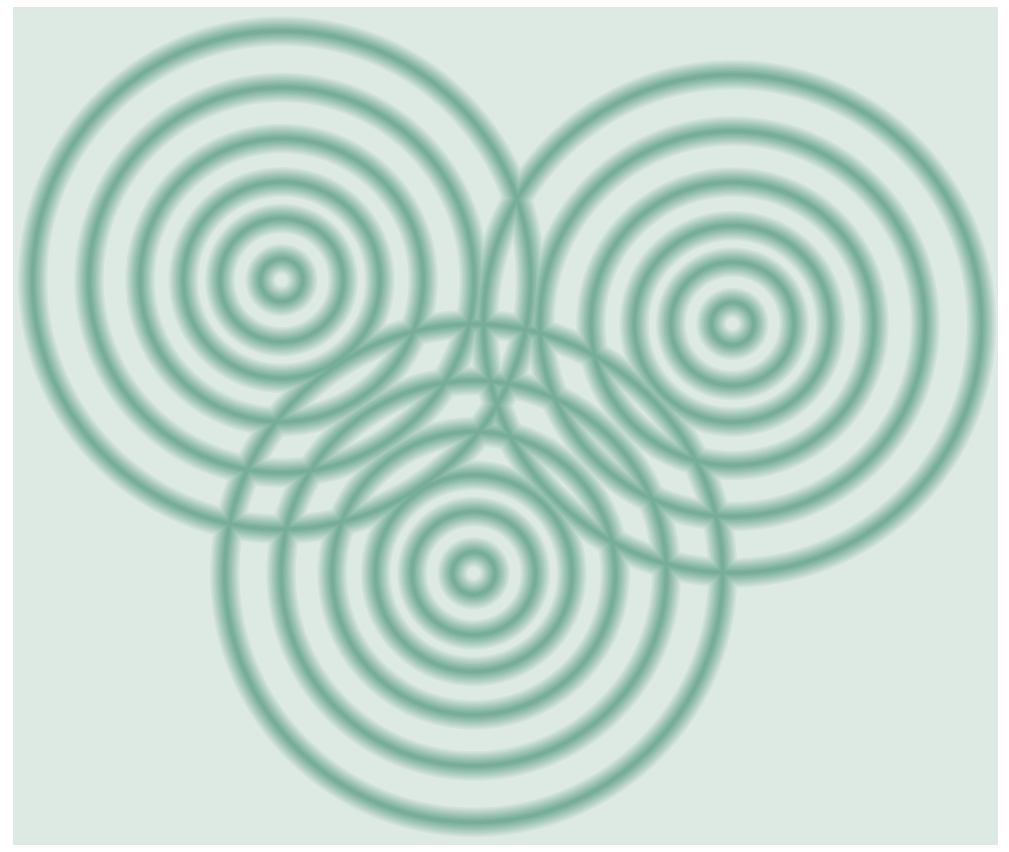

Figur 11: Skjematisk framstilling av bølgemodellen

Bølgemodellen virker mer realistisk som bilde på hvordan språkendringer sprer seg, ettersom dialektgrenser ikke er stabile, men tvert imot ofte kan gå på ulike måter i forskjellige perioder. Dette er heller ikke merkverdig. Dialektkartet reflekterer nemlig i veldig stor grad kommunikasjonsmønsteret i et område. Det vil si at folk som har mye kontakt, snakker relativt likt, mens folk som sjelden eller aldri treffes, vil komme til å snakke forskjellig når det er gått noen generasjoner. Dersom kommunikasjonsmønstrene endrer seg gjennom tida, for eksempel på grunn av økonomiske forandringer eller politiske omveltninger, så vil dialektkartet også etter hvert bli prega av dette, på den måten at gamle grenser kan flytte på seg eller nye skiller oppstå. 


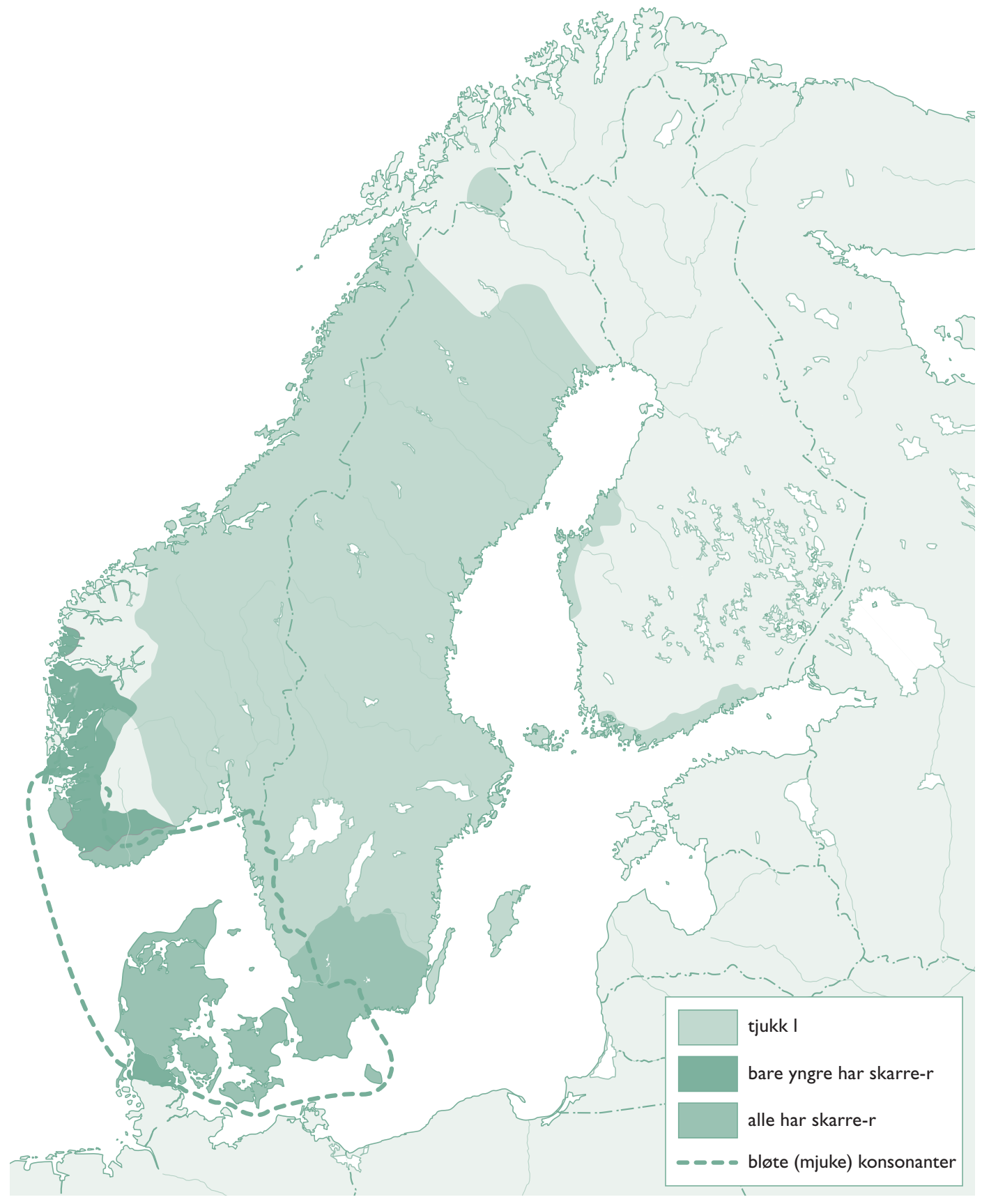

Figur 12:Tre skandinaviske uttaleforskjeller illustrert ved hjelp av bølgemodellen 


\section{Tjukk I}

Tjukk $l$ vil si den $l$-en som folk f.eks. i det østlige Norge og den nordlige delen av Sverige har i ord som dal og sol, og ofte også for rd i ord som bord og jord.

Dette er en lyd som folk som ikke er vokst opp med den, oftest har store problemer med å få til om de prøver, og slik har det nok alltid vært. Den svenske språkmannen Samuel Columbus hevda f.eks. omkring 1680 at det fantes «ett tiockt ell i Swenskan» som han mente ingen fremmede kunne uttale.

Språkvitenskapelig blir denne lyden betegna som en såkalt flap, dvs. at tunga bøyes bakover i munnen og kastes så framover slik at den undervegs slår mot gommen i overkjeven. Dette er lett for den som har øvd seg fra barnsbein av, men temmelig umulig å få til for den som prøver for første gang i voksen alder!

Tjukk $l$ er faktisk et ganske eksotisk fenomen i Europa, ettersom den bare forekommer på en del av norsk og svensk (inkludert finlandssvensk) område. I India er det derimot mange språk som har denne lyden, så i verdensmålestokk kan den neppe kalles noen sensasjon.

\section{Mjuke konsonanter}

Mjuke konsonanter vil si at ord som bryte, krype, ryke blir uttalt som bryde, krybe, ryge e.l. - altså at $p, t, k$ inne i og i slutten av ord blir til $b, d, g$. Dette er ei uttaleforandring som har starta i Danmark; i gammel dansk var det nemlig også $p, t, k$, slik det fremdeles er i vanlig svensk og norsk. Men i Danmark har denne formjukinga gått langt videre enn i de sørsvenske og sørvestnorske dialektene som er berørt: I mange danske dialekter er det faktisk slik at disse konsonantene er helt borte (brye/bryd, kryw, ryy), og også i riksdansk er utviklinga gått mye lenger enn i noen form for svensk eller norsk. Dette er dermed utvilsomt ei av de lydforandringene som gjør at svensker og nordmenn synes dansker snakker utydelig!

\section{Skarre-r}

Skarre-r er den $r$-en som brukes i bl.a. dansk og sørsvensk, i motsetning til tungespiss- $r$, som brukes av de fleste svensker og nordmenn. Forskjellen mellom disse to $r$-typene ligger i hvilken del av tunga som er mest aktiv: Ved tungespiss- $r$ er det som navnet sier, tungespissen eller den fremre delen av tunga som slår eller vibrerer 
mot gommen i overmunnen, mens skarre- $r$-en uttales ved at den bakre delen av tunga heves mot den såkalte mjuke ganen, dvs. den bakerste delen av munntaket, slik at det oppstår en vibrasjon eller friksjon mellom tunga og ganen eller drøvelen.

Av disse tre forskjellene representerer både tjukk $l$ og mjuke konsonanter gamle fenomener, som begge kan ha oppstått for over tusen år siden. Den tjukke $l$-en har rimeligvis oppstått et eller annet sted sentralt på den skandinaviske halvøya, mens de mjuke konsonantene som nevnt har sitt utgangspunkt i Danmark. Den tjukke l-en har så utelukkende spredd seg ved dialektkontakt over land. Spredningsmønsteret for de mjuke konsonantene til svensk og norsk område viser derimot tydelig at det må være tale om sjøvegs kontakt. Grensene for både tjukk $l$ og mjuke konsonanter stabiliserte seg antagelig alt for mange hundre år siden.

Skarre-r-en er utvilsomt et mye nyere fenomen. Før siste halvdel av 1700-tallet fantes det knapt andre som skarra i hele Skandinavia enn enkeltpersoner med talefeil. Men i løpet av de neste par hundre åra spredde skarre-r-en seg til hele det området som er vist på kartet (figur 12), og på Vestlandet i Norge ekspanderer den fremdeles. Utgangspunktet for skarre-r i Vest-Europa var sannsynligvis Paris på slutten av 1600-tallet. I Skandinavia kom den trulig først til København, og derfra «hoppa» den til større byer som Malmö, Bergen, Stavanger og Kristiansand.

\section{Mer og mindre fantasifulle forklaringer på opphavet til skarre-r-en}

Om skarre-r-en fins det mange artige teorier, men dessverre er de sannsynligvis ikke riktige. Ei populær forklaring går ut på at opphavet skal ha vært en fransk konge med skarre-r som talefeil, og så tok hoffolka etter kongen for å smigre han. Det som virker usannsynlig ved denne hypotesen, er at en individuell talefeil skulle kunne ha en slik smitteeffekt, samme hvor kongelig opphavsmannen måtte være.
Hvis det dessuten var klart for alle

- inklusive personen sjøl - at det dreide seg om en individuell talefeil, ville det vel i grunnen være ganske risikabelt å imitere den; det kunne kanskje snarere bli oppfatta som karikering enn som språklig «solidarisering».

Den danske språkmannen Otto Jespersen har ei helt annen forklaring. Han resonnerer som så at den gangen 
folk for det meste oppholdt seg i

friluft på landsbygda, så kunne språk-

lydene lett drukne i vindsus og fossedur, og da måtte de bruke en kraftig tungespiss-r for å kunne høre hverandre. Men i byen lever folk for det meste innadørs, og da er det ikke behov for en så anstrengende lyd lenger.

[L]ivet inden døre medfører i det hele sagte talen, man buldrer ikke så meget på, dels fordi det er overflødigt, dels fordi det kan være uforsigtigt ('væggene har øren'); jo mere raffineret stuelivet er, med tæpper på gulvet og portierer for dørene, des mere afdæmpet blir også sproget.
Den riktige forklaringa på opphavet er sannsynligvis å finne i visse ganske normale språklige utviklinger i pariserfransk på 1600-tallet og har dermed ingenting å gjøre verken med talefeil eller urban livsstil. Den raske spredninga til andre deler av Vest-Europa, i første omgang spesielt til byer, kan nok derimot delvis ha å gjøre med at skarre-r-en faktisk er enklere å uttale enn en tungespiss-r. Når skarre-r så først var etablert som en akseptabel $r$-uttale ved at den hadde fått innpass i det prestisjefylte pariserspråket, så lå vegen åpen for en rask parademarsj gjennom store deler av Vest- og Nord-Europa.

Bølgemodellen illustrerer tydelig hvordan forandringer kan oppstå på forskjellige steder innafor et dialektområde, og hvordan kommunikasjonsmønsteret kan påvirke den framtidige spredninga av fenomenene.

Stamtremodellen får det derimot til å se ut som om ei deling på ett bestemt tidspunkt får konsekvenser for alle seinere delinger - greinene i treet kan nemlig ikke vokse sammen igjen seinere, ja, ikke en gang nærme seg hverandre. Det er denne fundamentale forskjellen som gjør stamtremodellen ubrukelig, dersom man vil at modellen skal gjenspeile de faktiske forskjellene og likhetene mellom de moderne nordiske språka. Hvordan de to modellene kan utfylle hverandre, skal vi komme tilbake til seinere. 


\section{Historisk inndeling av nordiske språk etter bølgemodellen}

Fra urnordisk til vikingtid

Før ca. år 700 kalles språket i Skandinavia urnordisk. Om det fantes dialektforskjeller den gangen, må de trolig ha vært små, og vi kjenner $\mathrm{i}$ alle fall ingen moderne dialektskiller som vi med sikkerhet kan føre tilbake til den perioden.

Urnordisk skiller seg sterkt fra alle seinere stadier av nordiske språk, men ser man f.eks. på utviklinga av personnavn, er det tydelig at der skjedde store forandringer i løpet av de neste 300-400 åra. Lange, pompøse navn som AnulaibaR og HarjawaldaR lyder alt omkring år 1000 som Óláfr og Haraldr - som jo slett ikke er så ulikt de moderne navneformene, f.eks. norsk/dansk: Olav/Harald, svensk: Olov/Harald, færøysk: Ólavur/Haraldur, islandsk: Ólafur/Haraldur.

Alt på denne tida må vi derfor regne med at den språklige avstanden til urnordisk var blitt så stor at språka ville vært innbyrdes uforståelige. Om det utenkelige skulle skjedd at en skandinav fra 500-tallet plutselig skulle ha dukka opp blant vikingene 400-500 år seinere, ville de altså høyst sannsynlig ikke kunnet forstå hverandre i det hele tatt. Derimot ville vi i dag sannsynligvis kunnet snakke relativt greit med folk som levde på 1500-tallet, forutsatt at vi holdt oss til emner som begge parter hadde forutsetninger for å mene noe om. Språkforandringene mellom 500 og 1000 var altså langt større enn mellom 1500 og 2000.

\section{Runeskrifta}

Kjeldene til kunnskap om det urnordiske språket er innskrifter på bein, metall og stein skrevet med spesielle tegn som vi kaller runer. Den mest berømte av alle urnordiske runeinnskrifter ble funnet på et gullhorn i Jylland i Danmark på 1700-tallet. Den lyder slik: ek HlewagastiR holtijaR horna tawido, som er utlagt: jeg Legjest fra Holt (el. Holtes sønn) gjorde hornet.

De eldste runeinnskriftene stammer fra ca. år 200. De såkalte eldre runene, eller futhark, som de også kalles, etter lydverdien på de seks første tegna, ser slik ut: 


\section{FAPFR<XP

\section{fuparkgw hn i j ë Rs t b e m I $n d o$}

Figur 13: Den eldre runerekka

Som vi ser, er det i alt 24 tegn, noe som antagelig passet nærmest perfekt til det urnordiske lydsystemet. For noen få runer er lydverdien usikker, men som vi ser, ligner de fleste tegna nokså mye på de tilsvarende latinske bokstavene vi bruker i dag, og i de tilfellene kan vi i alle fall være sikre på at uttalen svarer til den vi kjenner fra andre språk som bruker dette alfabetet. Denne likheten viser at den eller de som skapte runene, kjente til ett eller flere av de alfabetene som var brukt i middelhavslanda. Selve fasongen på tegna - rette streker som står loddrett eller på skrå - tyder imidlertid på at de opprinnelig har vært beregna på å skjæres inn i tre med kniv - med den slags materiale og redskap er det nemlig lite hensiktsmessig å bruke tegn som inneholder buer og vannrette streker. Fra urnordisk tid er det likevel ikke bevart en eneste innskrift på tre, sannsynligvis fordi tre er et forgjengelig materiale. Alle bevarte urnordiske innskrifter er derfor rissa inn på stein, metall eller bein.

Omkring 700 blir den gamle runerekka forenkla ved at en reduserer antallet tegn fra 24 til 16. Det paradoksale er imidlertid at omtrent samtidig får språket flere forskjellige lyder, slik at en egentlig hadde bruk for flere og ikke færre tegn enn før, dersom hver lyd skulle ha sitt tegn. Hvorfor dette skjer, vet vi ikke, men det må ha et eller annet å gjøre med de store språkforandringene på denne tida. Kanskje man tenkte som så at når 24 tegn $i$ alle fall ikke lenger var nok til å gjengi alle lydene i språket, så var det kanskje ikke så farlig om ikke hver lyd hadde sitt eget tegn; sammenhengen viste jo som regel hva som var ment. 
Runene gikk i alle fall ikke dukken fordi om det ble færre tegn og sjøl om runerekka fra 1000-tallet også måtte konkurrere med det latinske alfabetet, som kom hit med kristendommen - tvert imot fortsatte de å være i bruk i mange hundre år etter at det latinske alfabetet var tatt $\mathrm{i}$ bruk. Og grunnen var sikkert den at runene på mange måter var enklere å bruke - ikke bare var det færre tegn å holde styr på, men det var først og fremst en mye enklere skriveteknikk - en kniv og en trepinne var nok dersom en ville rable ned en kort beskjed, mens latinske bokstaver krevde fjørpenn, blekk og kalveskinn.

Da runene omsider måtte gi tapt for det latinske alfabetet utpå 1400-tallet, kunne de altså se tilbake på nærmere 1500 års sammenhengende bruk i Norden, altså en halv gang til så lenge som det alfabetet vi bruker i dag!

\section{$\forall \cap P * R Y *+1 \nmid h \uparrow B \Psi \wedge \lambda$

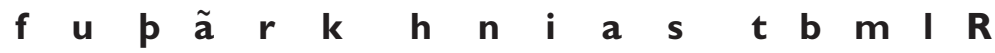

Figur 14: Den yngre runerekka

\section{Østnordisk og vestnordisk}

De eldste dialektforskjellene vi kjenner til innafor nordisk, er ei begynnende differensiering i et øst- og et vestnordisk område $i$ løpet av 700-800-tallet. Men fremdeles fantes det bare ett nordisk dialektkontinuum: Alle som snakka nordiske språk, bodde nemlig den gangen fremdeles i Skandinavia eller var ganske nylig utvandra derfra - til øyene vest i Atlanterhavet, til Storbritannia, Normandie, Russland osv. 
Dette er grunnen til at nordiske språk ofte kalles skandinaviske språk; før den store ekspansjonen i vikingtida ble nemlig disse språka bare snakka i Skandinavia.

Dialektforskjellene på denne tida var også helt ubetydelige. Både skandinavene sjøl og andre folk oppfatta nordisk som ett språk, som gjerne ble kalt dọnsk tunga, dvs. dansk tungemål. Hvorfor det akkurat var danskene som fikk æra av å representere hele Skandinavia språklig, er ikke helt klarlagt, men en mulighet er at betegnelsen kan ha oppstått i England, der danskene dominerte i vikingtida. Deretter har navnet dọnsk tunga blitt overført på alt nordisk språk sjøl om det ikke var «dansk» i snever forstand, men for alle utenforstående måtte det fortone seg som det samme språket.

Etter 700 dukker det etter hvert opp visse forskjeller, som følger et slikt mønster at det kan være naturlig å snakke om en vestlig og østlig grein av nordisk.
vestnordisk
østnordisk
islandsk, færøysk, norsk
svensk, dansk

Figur 15 a: Inndeling av nordiske språk ca. 700-1200

Vestnordisk vil i denne perioden grovt sett si norsk - etter landnåmet på Færøyene og Island (dvs. fra slutten av 800-tallet) også medregna færøysk og islandsk. Det var for det meste folk fra Norge, særlig Vestlandet, som slo seg ned på disse øyene, noe som preger språket der den dag i dag.

Østnordisk blir da resten av det nordiske området, altså dansk og svensk.

Flere forskjeller mellom moderne nordiske språk kan spores helt tilbake til denne perioden, dvs. til dialektsplittinga i vest- og østnordisk. Som eksemplene nedenfor viser, går islandsk, færøysk og nynorsk i slike tilfeller sammen mot dansk og svensk. Norsk bokmål følger som rimelig kan være, av og til dansk, men ikke alltid. 


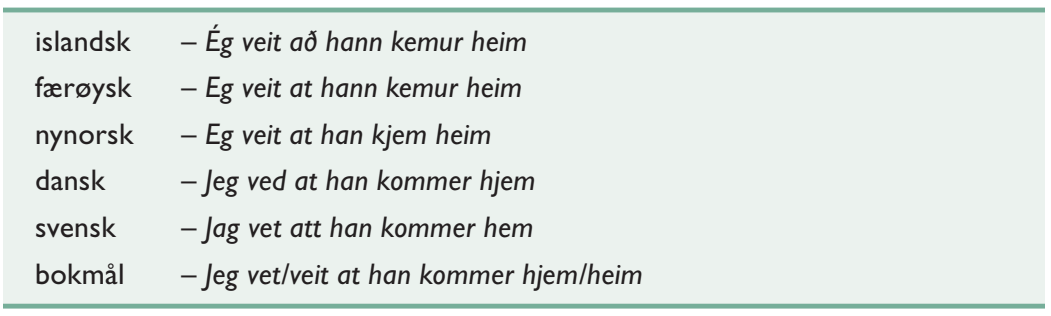

Figur 16: Eksempler på vestnordiske/østnordiske forskjeller mellom moderne nordiske språk

Her er noen av de viktigste forskjellene som kan spores helt tilbake til oppdelinga i vest- og østnordisk:

1. førstepersonspronomenet med eller uten $j(e ́ g / e g: j e g / j a g)$,

2. presensforma av verbet komme med eller uten vokalskifte (kemur/kjem : kommer)

3. og sist, men ikke minst, diftong (tvelyd, ei) eller monoftong (enkeltvokal, e) i de to orda veit : vet/ved og heim: hem/hjem.

I det store og hele var likevel forskjellene mellom de nordiske språka fram til vikingtida relativt ubetydelige, noe som er markert med en enkelt strek som skille i figur 15 a.

\section{I høgmellomalderen: nordnordisk og sørnordisk}

Etter ca. 1200 er det tydelig at det viktigste skillet - markert med to streker i figur $15 \mathrm{~b}$ nedenfor - nå går mellom dansk, som vi da kan kalle sørnordisk - og resten av det nordiske området, som kan kalles nordnordisk. At det primære skillet nå går annerledes, har trolig sammenheng med ei eller anna samfunnsmessig endring. Muligens var det sterkere kontakt enn før med tysk i Danmark, mens NordSkandinavia foreløpig ikke ble så sterkt berørt av denne fremmede kontakten.

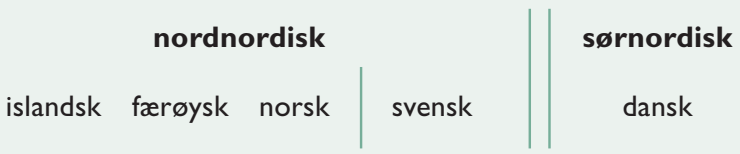

Figur 15 b: Inndeling av nordiske språk ca. 1200-1500 
De danske nyutviklingene er til delvis slike forandringer som seinere også viser seg i norsk og svensk - det gjelder særlig forenklinga av bøyingsverket; jf. avsnittet nedenfor. Men vi finner også danske særutviklinger. Det gjelder bl.a. den såkalte vokalsvekkelsen, som rammer vokaler i endestavelser:

- Dansk har i dag bare én vokal i grammatiske endelser, nemlig e. Det samme gjelder også stort sett norsk bokmål.

- Nynorsk og svensk har i tillegg ofte $a$ og i visse tilfeller også $o$.

- Islandsk og færøysk har $a$ i stort sett de samme formene som svensk og nynorsk har det, men derimot $i$ og $u$ i stedet for $e$ og $o$.

Som illustrasjon kan vi bruke flertallsformene bakker, sønner og viser av substantiv og presensformene kaster og kjenner av verb:

\begin{tabular}{llllll}
\hline islandsk: & bakkar & synir & vísur & kastar & kennir \\
færøysk: & bakkar & synir & vísur & kastar & kennir \\
nynorsk: & bakkar & søner & viser/visor & kastar & kjenner \\
svensk: & backar & söner & visor & kastar & känner \\
bokmål: & bakker & sønner & viser & kaster & kjenner \\
dansk: & bakker & sønner & viser & kaster & kender \\
\hline
\end{tabular}

Figur 17: Eksempler på vokalsvekkelse: Forskjeller mellom nordnordiske og sørnordiske endestavelser

Dessuten får dansk i denne perioden en rekke særutviklinger, som bare i svært liten grad sprer seg til resten av det nordiske området. Det gjelder bl.a. den omtalte utviklinga av de såkalte bløte eller mjuke konsonantene, dvs. overgangen fra $p, t, k$ til $b, d, g$ etter vokal. Eksempler på dette er dansk gabe, bide, kage mot norsk gape, bite, kake og svensk gapa, bita, kaka. Denne overgangen fins for øvrig også i dialektene i Sør- og Vest-Sverige og på sørvestkysten i Norge; jf. figur 12 ovenfor. Pussig nok fins ei tilsvarende utvikling også i den sørlige delen av både det færøyske og det islandske språkområdet, slik at en kunne få en mistanke om at mjuke konsonanter var et slags "sydlandsk» innfall, men ettersom avstanden mellom Færøyene, Island og Sør-Skandinavia er så stor, må en nok helst anta at det er uavhengige utviklinger uten noen indre sammenheng. 
Men dansk får også diverse lydforandringer som ikke kommer fram i skrift, f.eks. det såkalte stødet, der svensk og norsk i stedet har tonelag eller tonem. Dette kan vi se om vi sammenligner uttalen av ord på norsk og svensk med tilsvarende ord på dansk:

- Tonem 1 på norsk og svensk, stød på dansk: bønder (dansk og norsk), anden (svensk, bestemt form av and)

- Tonem 2 på norsk og svensk, ikke stød på dansk: bønner (dansk og norsk); anden (svensk, bestemt form av ande)

- Islandsk og færøysk har verken tonem eller stød.

\section{Tonem og stød}

Tonem vil si betydningsskillende tonegang. Stød er derimot et tilnærma stemmebandslukke, dvs. at man nesten stopper luftstrømmen i strupehodet, for så plutselig å åpne igjen.

Både tonem og stød er altså noe annet enn en enkelt språklyd - en enkelt vokal eller konsonant - og det er heller ikke det samme som trykk, for alle eksemplene ovenfor har trykket på den første stavelsen, mens ord som idé eller hotell vanligvis har trykk på den siste stavelsen.

Tonem er et relativt sjeldent fenomen i Europa - blant vesteuropeiske språk fins det således bare i norsk og svensk. Derimot er tonemer veldig vanlige $\mathrm{i}$ andre deler av verden, f.eks. i Afrika og i Øst-Asia.Verdens største språk - mandarinkinesisk - har f.eks. fire forskjellige tonemer.
Tonemene i norsk og svensk er antagelig omkring tusen år gamle. Det er vanlig å anta at det danske stødet er utvikla av et eldre system med tonem, som i norsk og svensk. Når stødet oppstod i dansk, er ikke godt å si, for det vises jo ikke i skrift, men alt tyder på at det også går tilbake til mellomalderen. Det eldste kjente skriftlige indisium for at dansk hadde fått stød, stammer fra 1510, da den svenske biskopen Hemming Gadh i en antidansk tale nokså uærbødig karakteriserte danskenes uttale slik:

Der til med så wärdas de icke heller tala som annat folck, uthan tryckia ordhen fram, lika som the willia hosta. (= Dessuten gidder de heller ikke snakke som andre folk, men trykker fram orda, som om de ville hoste.) 
Som vi ser, fins det ingen skillelinjer i figur 15 b mellom norsk og de to norske «emigrantspråka» islandsk og færøysk. Dette er nok strengt tatt en liten tilsnikelse, for vi vet at det fantes små forskjeller mellom islandsk og norsk alt før 1200. Men helt fram til begynnelsen av 1300-tallet var disse forskjellene sikkert mindre enn skillene mellom de ulike språkformene innafor Skandinavia.

\section{Nyere tid: øynordisk og skandinavisk}

Når vi nærmer oss 1500, blir bildet derimot et helt annet. Nå går etter hvert hovedskillelinjene innafor nordisk nettopp mellom de tre språka islandsk, færøysk og norsk. Det sier seg sjøl at så store forskjeller oppstår ikke over natta; de må tvert imot ha utvikla seg gradvis over lang tid.

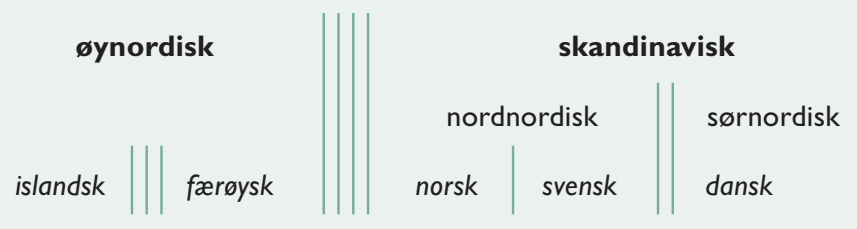

Figur 15 c: Inndeling av nordiske språk etter ca. 1500

Grunnen til at vi nå får ei helt ny inndeling, er den at vi nå for alvor ser de kommunikative følgene av den store geografiske avstanden mellom Skandinavia og de atlantiske øysamfunna. Riktignok var det en god del kontakt mellom emigrantsamfunna og det gamle moderlandet Norge i de første hundreåra etter utvandringa på 800-900-tallet, men etter ca. 1300 blir det stadig mindre, og i seinere tid gikk forbindelsene med Skandinavia mer og mer over Danmark, ettersom København nå var hovedstaden i det felles dansk-norske kongeriket. Den kontakten som eksisterte da, skjedde for det meste gjennom danske embets- og handelsmenn, som var ganske fåtallige og heller ikke hadde veldig mye omgang med lokalbefolkningen.

Talemålet i Skandinavia forandrer seg sterkt i seinmellomalderen, men langt på veg «i takt», slik at forskjellene innafor Skandinavia ikke øker vesentlig. Endringene i begge de øynordiske språka er derimot langt mindre. Særlig gjelder dette islandsk, som er det mest konservative av alle germanske språk. 
Resultatet av dette blir at språkforskjellene mellom disse tre geografisk skilte områdene blir større enn noen av de tidligere nordiske dialektskillene. Det primære skillet er nå øynordisk mot skandinavisk, markert med fire streker, og dernest islandsk mot færøysk, markert med tre streker. Forskjellene mellom disse tre områdene - Island, Færøyene og Skandinavia - er nå så store at innbyrdes forståelighet ikke lenger er mulig. Dette gjelder i alle fall mellom ytterpunktene - dvs. islandsk og skandinavisk. Færøyingene, som både språklig og geografisk ligger i midten, har nok en viss mulighet for å forstå islandsk, og skandinavisk i nær sagt alle mulige utgaver forstår de uten problemer, først og fremst fordi de har grundige skolekunnskaper i dansk, mens den færøyske uttalen ligner mer på norsk og svensk uttale enn på dansk. Færøyingene har dermed de beste forutsetningene av alle til å forstå samtlige nordiske språk.

Den innbyrdes forståelsen mellom islandsk og færøysk går imidlertid i beste fall bare den ene vegen - islendinger forstår lite av færøysk. Som vi har vært inne på før, kan dette bl.a. henge sammen med at det færøyske språksamfunnet er så mye mindre enn det islandske.

Innafor Skandinavia har vi derimot fremdeles stort sett gjensidig forståelse, slik det tidligere var innafor hele det nordiske språkområdet. Dette temaet skal vi komme tilbake til mot slutten.

\section{Hvorfor er skandinavisk og øynordisk avstandsspråk?}

De øynordiske språka er som nevnt mer konservative enn de skandinaviske, og spesielt gjelder det altså islandsk. Færøysk havner på mange måter i en slags mellomstilling. Dette ser vi f.eks. lett om vi sammenligner bøyingssystemet i de tre områdene.

\section{Forskjellig bøying}

I mellomalderen og tidligere fikk både substantiv, adjektiv og pronomener forskjellige former avhengig av hvordan de ble brukt i setningen - som subjekt, objekt, etter ymse preposisjoner osv. I nordisk og andre germanske språk var det fire slike kasus - nomi$\operatorname{nativ}(\mathrm{N})$, akkusativ (A), dativ (D) og genitiv (G). Alle disse fins fremdeles på islandsk - og tysk, som også har bevart ganske mange eldre bøyingsformer. Færøysk har stort sett mista genitiv, og på skandinavisk er alle kasus borte i substantiv. 


\section{Merknad om genitiv}

Mange mener at genitiv fremdeles eksisterer som kasus i moderne skandinavisk i form av den velkjente s-endelsen som i Gunnars hest, som på norrønt ville kunne hete enten Gunnars hestr eller hestr Gunnars. Men denne s-en oppfører seg mer som et eget ord enn som en endelse på sjølve substantivet, for dersom det er Gunnar på Lidarende som eier hesten, så sier vi på moderne skandinavisk «Gunnar på Lidarendes hest». Her ser vi altså at s-en knytter seg til hele ordgruppa
Gunnar på Lidarende. På norrønt - og moderne islandsk - blir det derimot slik: hestr (islandsk: hestur) Gunnars á Hlíðarenda. Her ser vi altså at s-en fremdeles er knytta bare til hovedordet Gunnar.

Dessuten er det bare som eiendomsgenitiv vi kan bruke s-form; i alle andre bruksmåter (f.eks. etter visse preposisjoner) er ikke genitiv lenger i bruk (f.eks. til byen, ikke til bys, derimot er genitiv bevart i faste uttrykk som til lands, til fots osv.).

Her ser vi hvordan det kan ta seg ut i de forskjellige språka; for å illustrere de forskjellige kasusformene i færøysk og islandsk har vi tatt med en preposisjon som krever vedkommende kasus:

\begin{tabular}{|c|c|c|c|}
\hline & $\begin{array}{l}\text { skandinavisk } \\
\text { - norsk }\end{array}$ & færøysk & islandsk \\
\hline \multicolumn{4}{|l|}{ entall } \\
\hline & hest & hestur $(N)$ & hestur $(N)$ \\
\hline & om hest & um hest $(A)$ & um hest $(A)$ \\
\hline & fra hest & frá hesti (D) & frá hesti (D) \\
\hline & til hest & til hest $(\mathrm{A})$ & til hests $(G)$ \\
\hline \multicolumn{4}{|l|}{ flertall } \\
\hline & hester & hestar $(N)$ & hestar $(\mathrm{N})$ \\
\hline & om hester & um hestar (A) & um hesta $(A)$ \\
\hline & fra hester & frá hestum (D) & frá hestum (D) \\
\hline & til hester & til hestar (A) & til hesta $(G)$ \\
\hline
\end{tabular}

Figur 18: Kasusformer i skandinavisk, færøysk og islandsk

Men skandinavisk har fremdeles rester av kasusbøying i pronomener; jf. jeg ser deg : du ser meg, der formene jeg/meg og du/deg er henholdsvis subjekts- og objektsform, noe som er en rest av nomina- 
tiv/akkusativ-skillet. I eldre språk og fremdeles i øynordisk er det ikke bare skille mellom ulike grammatiske kjønn i entallspronomener som han og hun, men også i flertall. Pronomenene har tre forskjellige former, avhengig av om de viser til flere personer av hankjønn, hunkjønn, eller ei gruppe der begge kjønn er representert. Dette er vist i eksempelsetningene nedenfor, der ordet de kan oversettes på tre forskjelllige måter.

\begin{tabular}{llll}
\hline & $\begin{array}{l}\text { skandinavisk } \\
\text { - norsk }\end{array}$ & færøysk & islandsk \\
\hline hankjønn & guttene: & dreingirnir: & strákarnir: \\
& de & teir & peir \\
\hline hunkjønn & jentene: & genturnar: & stelpurnar: \\
& de & tær & pær \\
\hline hankjønn + & guttene og & dreingirnir og & strákarnir og \\
hunkjønn & jentene: & genturnar: & stelpurnar: \\
& de & tey & pau \\
\hline
\end{tabular}

Figur 19: Pronomen 3. person flertall

I verb hadde eldre nordisk forskjellige former avhengig av om subjektet var entall eller flertall, eller om subjektet var et pronomen i 1. eller 2. person; jf. engelsk the boy comes : the boys come og I am : you are. Islandsk har bevart både tall- og personbøying, færøysk har mista personbøying i flertall, mens moderne skandinavisk har mista både tall- og personbøying.

\begin{tabular}{llll}
\hline & $\begin{array}{l}\text { skandinavisk } \\
- \text { norsk }\end{array}$ & færøysk & islandsk \\
\hline entall & & & \\
\hline 1. person & jeg står & eg standi & eg stend \\
\hline 2. person & du står & tú stendur & pú stendur \\
\hline 3. person & han/hun står & han/hon stendur & hann/hún stendur \\
\hline flertall & & & \\
\hline 1. person & vi står & vit standa & við stöndum \\
\hline 2. person & dere står & tit standa & pið standið \\
\hline 3. person & de står & teir/tær/tey standa & peir/pær/pau standa \\
\hline
\end{tabular}

Figur 20: Tall- og personbøying av verb 
Svensk skriftspråk holdt imidlertid på tallbøying helt til midten av 1900-tallet (pojken kommer : pojkarna komma), mens den forsvant $\mathrm{i}$ skriftlig dansk og norsk på 1800-tallet. Her er ei skjematisk oppsummering av forskjellene:

\begin{tabular}{lccc}
\hline & islandsk & færøysk & skandinavisk \\
\hline antall kasus & & & \\
\hline a) i subst. og adjektiv & 4 & 3 & 0 \\
\hline b) i pronomen & 4 & 3 & 2 \\
\hline kjønnsbøying i flertall & + & + & - \\
\hline tallbøying i verb & + & + & - \\
\hline a) i entall & + & + & - \\
\hline b) i flertall & + & - & - \\
\hline
\end{tabular}

Figur 21: Oversikt over skandinaviske og øynordiske bøyingsformer

I setningene nedenfor kan vi se hvordan dette virker i praksis når vi setter sammen alt det vi har sett på ovenfor.

\section{ISLANDSK}

Som det går fram av figur 21, er islandsk det eneste av de nordiske språka som fremdeles har personbøying av verb både i entall og flertall og dessuten fire kasus i substantiv. I eksemplene nedenfor ser vi hvordan det virker i praksis ved verba komme, se, stå og sakne kombinert med substantivet hest $\mathrm{i}$ alle kasus i bestemt form entall og flertall og med forskjellige personlige pronomener som subjekt.

\begin{tabular}{llll}
\hline ENTALL & & & \\
\hline nominativ & hesturinn kemur & genitiv \\
\hline & akkusativ & dativ & ég sakna hestsins \\
\hline 1.person & ég sé hestinn & ég stend hjá hestinum & pú saknar hestsins \\
\hline 2. person & pú sérð hestinn & pú stendur hjá hestinum & pún \\
\hline 3. person & hann/hún & hann/hún & hann/hún \\
& sér hestinn & stendur hjá hestinum & saknar hestsins \\
\hline
\end{tabular}




\begin{tabular}{llll}
\hline FLERTALL & & & \\
\hline nominativ & hestarnir koma & & \\
\hline & akkusativ & dativ & genitiv \\
\hline 1. person & $\begin{array}{l}\text { við sjáum } \\
\text { hestana }\end{array}$ & $\begin{array}{l}\text { við stöndum hjá } \\
\text { hestunum }\end{array}$ & $\begin{array}{l}\text { við söknum } \\
\text { hestanna }\end{array}$ \\
\hline 2. person & pið sjáið hestana & pið standið hjá hestunum & pið saknið hestanna \\
\hline 3. person & peir/pær/pau & peir/pær/pau standa & $\begin{array}{l}\text { peir/pær/pau } \\
\text { sjá hestunum hestanna }\end{array}$ \\
& sjá hestana & sjá hana & \\
\hline
\end{tabular}

\section{FÆRØYSK}

Når vi tar de samme setningene på færøysk, legger vi merke til to viktige forskjeller:

a) Kasusen genitiv er borte i substantivet (jf. eg síggi/sakni hestin (akkusativ) mot islandsk: ég sé hestinn (akkusativ), men ég sakna hestsins (genitiv) - på islandsk krever nemlig verbet sakna at objektet skal stå i genitiv).

b) Personbøyinga av verbet er borte i flertall (alle flertallsformene ender på -a: síggja, standa, sakna; mot islandsk sjáum - sjáiðsjá; stöndum-standið-standa; söknum-saknið-sakna).

\begin{tabular}{llll}
\hline ENTALL & & & \\
\hline nominativ & hesturin kemur & & akkusativ \\
\hline 1. person & eg síggi hestin & eg standi hjá hestinum & eg sakni hestin \\
\hline 2. person & tú sært hestin & tú stendur hjá hestinum & tú saknar hestin \\
\hline 3. person & $\begin{array}{l}\text { hann/hon sær } \\
\text { hestin }\end{array}$ & $\begin{array}{l}\text { hann/hon stendur } \\
\text { hjá hestinum }\end{array}$ & $\begin{array}{l}\text { hann/hon saknar } \\
\text { hestin }\end{array}$ \\
\hline
\end{tabular}

\begin{tabular}{llll}
\hline FLERTALL & & & \\
\hline nominativ & hestarnir $(\mathrm{N})$ koma & & \\
\hline & akkusativ & dativ & akkusativ \\
\hline 1. person & vit síggja hestarnar & vit standa hjá hestunum & vit sakna hestarnar \\
\hline 2. person & tit síggja hestarnar & tit standa hjá hestunum & tit sakna hestarnar \\
\hline 3. person & $\begin{array}{l}\text { teir/tær/tey síggja } \\
\text { hestarnar }\end{array}$ & $\begin{array}{l}\text { teir/tær/tey standa } \\
\text { hjá hestunum }\end{array}$ & $\begin{array}{l}\text { teir/tær/tey sakna } \\
\text { hestarnar }\end{array}$ \\
\hline
\end{tabular}


NORSK BOKMÅL

Her har vi så det moderne skandinaviske systemet uten kasusbøying i substantiv og uten tall- og personbøying i verb.

\begin{tabular}{llll}
\hline \multicolumn{3}{l}{ ENTALL } & \\
\hline & hesten kommer & \\
\hline 1. person & jeg ser hesten & jeg står hos hesten & jeg sakner hesten \\
\hline 2. person & du ser hesten & du står hos hesten & du sakner hesten \\
\hline 3. person & $\begin{array}{l}\text { han/hun ser } \\
\text { hesten }\end{array}$ & $\begin{array}{l}\text { han/hun står } \\
\text { hos hesten }\end{array}$ & $\begin{array}{l}\text { han/hun sakner } \\
\text { hesten }\end{array}$ \\
\hline
\end{tabular}

\section{FLERTALL}

hestene kommer

\begin{tabular}{llll}
\hline 1. person & vi ser hestene & vi står hos hestene & vi sakner hestene \\
\hline 2. person & dere ser hestene & dere står hos hestene & dere sakner hestene \\
\hline 3. person & de ser hestene & de står hos hestene & de sakner hestene
\end{tabular}

Sammenligna med det eldre fellesnordiske utgangspunktet kan vi altså konstatere at islandsk fremdeles har bevart bøyingssystemet stort sett slik som det var for omkring tusen år siden, mens færøysk har mista en del gamle bøyingsformer, men på langt nær så mye som de skandinaviske språka.

\section{Forskjellig uttale}

Det er nok imidlertid ikke først og fremst de morfologiske forskjellene - dvs. bøyingsformene - som gjør at islandsk og færøysk er avstandsspråk i forhold til skandinavisk. To andre språklige nivåer er utvilsomt langt viktigere, nemlig det fonologiske (lydene) og det leksikalske (ordforrådet). Dette kan vi se når vi sammenligner de tre setningene nedenfor: a-versjonen er normal islandsk ortografi, b-versjonen er den samme setningen i lydskrift, mens c-versjonen er en norsk oversettelse: 
1. a. Konan talaði við manninn sinn um bílinn.

b. /ko:nan ta:laði vi:ð man:in sin Ym bi:Iın/

c. Kona talte med mannen sin om bilen.

2. a. Kerlingin mætti tröllinu á fjallinu.

b. /kjerdlingjin mai ${ }^{h_{t}}$ : trødlınY au fjadlınYI

c. Kjerringa møtte trollet på fjellet.

3. a. Sjónvarpið bilaði pegar ég var að horfa á fréttirnar.

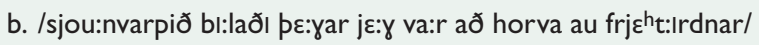

c. Fjernsynet gikk i stykker mens jeg så på nyhetene.

Figur 22: Islandsk (skrift og tale) kontra skandinavisk

Av disse islandske setningene ville trolig nr. 1 være forståelig for de fleste skandinaver både i skrift og tale, mens nr. 2 neppe ville være det i tale, men sannsynligvis i skrift, og nr. 3 sikkert helt ubegripelig uansett om det er tale eller skrift. Forklaringa er også ganske opplagt:

- I nr. 1: Konan talađi við manninn sinn um bílinn er sjølve orda - glosene - nesten identiske, og det lydlige stemmer også relativt bra.

- I nr. 2: Kerlingin moetti tröllinu á fjallinu er glosene også de samme, men lydutviklinga i islandsk og skandinavisk har gjort dem nokså ugjenkjennelige for en skandinav som bare făr høre setningen, mens den skriftlige versjonen virker langt mindre fremmed.

- I nr. 3: Sjónvarpið bilađi pegar ég var að horfa á fréttirnar er derimot nesten alle orda helt ulike, og da hjelper det lite om lydutvikling og andre forhold stemmer aldri så godt overens.

\section{Orda betyr mest for forståelsen}

En veldig viktig - kanskje den mest avgjørende - forutsetning for forståelighet mellom språk er altså at sjølve orda ligner hverandre, enten i tale eller skrift - eller helst begge deler. I skandinavisk ble imidlertid en veldig stor del av det nedarva nordiske ordforrådet skifta ut med nedertyske (plattyske) ord i løpet av seinmellomalderen på grunn av den intensive språkkontakten med hanseatiske, dvs. nordtyske, kjøpmenn, som i en lang periode dominerte hande- 
len i hele Skandinavia. Og denne kontakten har så visst satt spor i språket: Et relativt forsiktig anslag går ut på at mellom 30 og 40 prosent av det daglige ordforrådet i de moderne skandinaviske språka stammer fra nedertysk.

\section{Moderne skandinaviske språk har mange tyske lånord}

Det er faktisk mulig å lage hele tekster der så å si alt annet enn grammatiske endelser og formord er tyske, slik som i denne ytringa, der bare de understreka orda er nordiske, mens resten er lånord fra tysk.
Skredderen mente at jakka passet fortreffelig, men kunden klaget over at plagget var kort og tøyet simpelt og grovt.

En av grunnene til forståelsesproblemer mellom de skandinaviske språka er at Norge, Sverige og Danmark har tatt opp forskjellige ord fra nedertysk. Totalt sett er sannsynligvis de tyske elementene i moderne skandinavisk relativt likelig fordelt i de ymse språka, men når der er forskjeller i ordvalget, går norsk og dansk som regel sammen mot svensk. Grunnen til at det er slik, er ganske enkelt den at Danmark og Norge i mange hundreår hadde dansk som felles skriftspråk. Ettersom danskene var hanseatenes nærmeste naboer i Skandinavia, er det rimelig at den tyske innflytelsen gjorde seg aller sterkest gjeldende i dansk, og mange av de tyske orda i norsk har utvilsomt funnet veien gjennom det danske skriftspråket. Men nordmennene har nok også hatt direkte kontakt med hanseatene, særlig i Bergen, som helt fram til 1800-tallet var Norges største by. Svenskene har derimot fått mange tyske ord via sine hansabyer, som Stockholm og Kalmar, og det er ofte andre tyske ord enn de som er kommet inn i dansk og norsk.

I tabellen nedenfor ser vi en del eksempler der de danske og norske orda er svært like hverandre - uansett om det er nynorsk eller bokmål - mens svensk har et annet ord for det samme begrepet. Disse likhetene og forskjellene skyldes her enten at norsk/dansk på den ene sida og svensk på den andre har valgt henholdsvis et nordisk eller et tysk ord, eller at man har valgt ulike nordiske eller tyske ord. 


\begin{tabular}{|c|c|c|}
\hline norsk & dansk & svensk \\
\hline spørje/spørre & spørge & fråga \\
\hline \multicolumn{2}{|c|}{ fra spyrja (norrønt) } & fra frâgen (nedertysk) \\
\hline vindauge/vindu & vindue & fönster \\
\hline \multicolumn{2}{|c|}{ fra vindauga (norrønt) } & fra fenster (nedertysk) \\
\hline mangel & mangel & brist \\
\hline \multicolumn{2}{|c|}{ fra mangel (nedertysk) } & fra brist (gammalsvensk) \\
\hline stilling & stilling & läge \\
\hline \multicolumn{2}{|c|}{ fra stelling (nedertysk) } & fra læghe (gammalsvensk) \\
\hline nå & nå & hinna \\
\hline \multicolumn{2}{|c|}{ fra ná (norrønt) } & fra hinna (gammalsvensk) \\
\hline samfunn & samfund & samhälle \\
\hline \multicolumn{2}{|c|}{ fra samfundr (norrønt) } & fra samhælde (gammalsvensk) \\
\hline omtrent & omtrent & ungefär \\
\hline \multicolumn{2}{|c|}{ fra umtrent (nedertysk) } & fra ungefêr (nedertysk) \\
\hline oppdage & opdage & upptäcka \\
\hline \multicolumn{2}{|c|}{ fra updagen (nedertysk) } & fra updecken (nedertysk) \\
\hline
\end{tabular}

Figur 23: Eksempler på leksikalske forskjeller mellom norsk og dansk kontra svensk. Under hvert ord står det norrøne/gammalsvenske eller nedertyske ordet som det moderne ordet kommer fra. I de fire første eksemplene kommer forskjellen av at norsk/dansk på den ene sida og svensk på den andre har valgt henholdsvis et nordisk eller et tysk ord - eller omvendt. I de to neste eksemplene er alle orda nordiske - men to forskjellige nordiske ord. I de to siste eksemplene stammer alle orda fra nedertysk, men igjen fra to forskjellige nedertyske ord.

\section{Er stamtremodellen moden for skraphaugen?}

Som vi så da vi kommenterte figur 5 , gir stamtremodellen ei misvisende inndeling av moderne nordiske språk, først og fremst fordi den plasserer norsk sammen med islandsk og færøysk som «vestnordisk». Dette svarer ikke til det vi opplever som ei rimelig inndeling i dag. Spørsmålet er så om hele stamtremodellen like godt kan oppgis til fordel for den tilsynelatende mer presise og nyanserte bølgemodellen.

Å trekke en slik konklusjon ville imidlertid være forhasta. Stamtremodellen er nemlig fremdeles det beste redskapet vi har for å 
framstille på en anskuelig måte hva historisk sammenheng i et språksamfunn innebærer. Spesielt viktig er det at en med denne modellen kan få fram hvilke språklige likheter som skyldes genetisk slektskap - arv - og hvilke overensstemmelser som bare skyldes kontakt - altså lån. Dette er et helt grunnleggende skille i sammenlignende språkvitenskap, og dermed er stamtremodellen også et uunnværlig grunnlag for denne vitenskapen. Dersom en begrenser seg til å forklare det at nye språktrekk oppstår og sprer seg, med et bilde av «bølger» som «skvalper» fritt hit og dit, blir arv og lån meningsløse begreper i språkforskinga, og det er neppe noe vitenskapelig framsteg.

Stamtremodellen kan virke som ei svært merkverdig inndeling av de moderne nordiske språka - det er jo nemlig slett ikke slik at norsk i dag ligner mer på islandsk og færøysk enn på svensk og dansk. Men forklaringa er at stamtremodellens oppdeling av det nordiske språkområdet i vestnordisk og østnordisk gjelder en periode da de nordiske språka ennå utgjorde ett dialektkontinuum i Skandinavia - før noen hadde emigrert til fjerne strøk.

Det som så skjedde, var at en del av skandinavene - nærmere bestemt en del av nordmennene - emigrerte til øyene i vest. Men de som reiste til Færøyene og Island, var selvfølgelig ikke alle de som snakka "vestnordisk» - storparten ble faktisk igjen i Norge. Denne utvandringa førte etter hvert til at den vestnordiske greinen «revna» i flere deler, fordi kontakten mellom utvandrerne og de som ble igjen, falt mer eller mindre bort, mens den interne kontakten innafor Skandinavia fortsatte som før. Dette er dermed grunnen til at begrepene øst- og vestnordisk er så lite opplysende når det gjelder å beskrive forholdet mellom de nordiske språka i dag.

Utviklinga av nordiske språk viser altså at det kan være risikabelt å tegne stamtre innafor et dialektkontinuum, dersom en ønsker at stamtreet også lenge etterpå skal vise den faktiske likheten mellom de forskjellige "greinene». En risikerer nemlig lett at det blir kluss med greinverket dersom et slikt kontinuum seinere blir splitta opp på grunn av utvandring til fjerne strøk. 


\section{Den skandinaviske nabospråksforståelsen - et hoved- element i den nordiske samkjensla}

Det normale når dansker, nordmenn og svensker (inklusive finlandssvensker) snakker sammen, er som kjent å bruke morsmålet, eventuelt med visse justeringer i ordvalg og uttale. De som snakker skandinaviske språk, oppfører seg altså i praksis som om de skandinaviske språka var «bare dialekter». Man regner med andre ord med at samtalepartneren forstår nabospråket. Dette er det tradisjonelle bildet av den såkalte nabospråkskommunikasjonen.

Som vi har vært inne på tidligere, står nordmenn i denne sammenhengen i en spesielt gunstig situasjon, i og med at de på grunn av det lange skriftspråksfellesskapet med danskene har det meste av ordforrådet felles med dansk, mens de på grunn av det nære geografiske naboskapet har det meste av uttalen felles med svenskene. Dette gir seg også tydelige utslag når det gjelder evnen til å forstå nabospråka. Her er et diagram som viser hvor mye folk fra de ulike skandinaviske landa forstår av nabospråket i talt form:

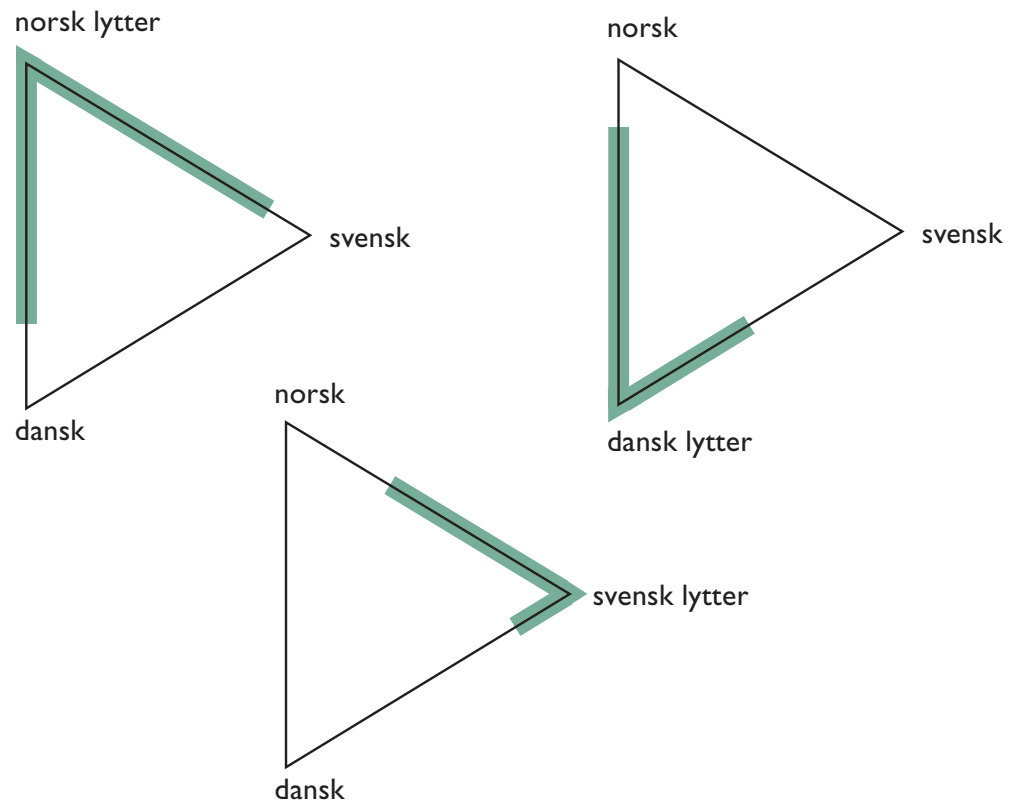

Figur 24: Skandinavisk nabospråksforståelse 
Skjemaet over bygger på en undersøkelse av danske, norske og svenske rekrutter, dvs. gutter i 19-årsalderen, og den ble utført i første halvdel av 1970-åra. Som vi ser, lå de norske guttene et godt hakk foran både dansker og svensker, men vi ser også at svenskene lå på en like suveren jumboplass; de forstod mye mindre av både norsk og (særlig) dansk. Som vi har vært inne på før, kan dette ha noe å gjøre med svenskenes tradisjonelle storebrorholdning - $\mathrm{i}$ og med at svenskene er så mange, regner de kanskje med at de mindre naboene vil «ta bryet» med å forstå svensk, mens de på si side ikke gidder prøve å forstå dansk og norsk, for å gi ei litt usympatisk tolking av den «skjeve» språkforståelsen mellom svenskene og naboene i sør og vest.

Dette er nok imidlertid ikke hele sannheten. Den omtalte undersøkelsen brukte nemlig bare informanter fra hovedstadsområdet $i$ de respektive tre landa, og dette vil nesten automatisk favorisere språkforståelsen hos danskene og nordmennene, i og med at både Oslo og spesielt København ligger veldig nær Sverige, mens Stockholm ligger langt fra både Norge og Danmark. Det er derfor ikke overraskende at folk i Stockholm forstår mindre av dansk og norsk enn folk i København og Oslo forstår av svensk, rett og slett fordi københavnere og oslofolk mye oftere treffer svensker, på grunn av den korte avstanden til Sverige.

Et ytterligere forhold som utvilsomt spilte ei viktig rolle i 1970åra, var fjernsynet, der både københavnere og oslofolk hadde teknisk mulighet til å se svensk tv - noe mange også gjorde - mens stockholmere verken kunne se dansk eller norsk fjernsyn. Dermed var det mange dansker og nordmenn som fikk masse gratis «svenskundervisning», mens ingenting gikk den andre vegen.

I en ny undersøkelse av nabospråksforståelsen som ennå ikke er avslutta, har man forsøkt å rette på denne «urettferdigheten» mot svenskene ved å sikre ei jevnere geografisk fordeling mellom informantene, slik at også Bergen i Norge, Århus i Danmark og Malmö i Sverige blir dradd inn i sammenligninga. Dette har som en kunne vente, ført til at forholdet mellom dansker og svensker nå framstår som mer jevnbyrdig enn i den eldre undersøkelsen. Nordmennene har imidlertid fremdeles en klar ledelse, noe som slett ikke er uventa ut fra språklige likheter og forskjeller mellom de tre skandinaviske språka: Som vi har vært inne på før, har nordmennene litt forenkla sagt uttalen felles med svenskene, og ordforrådet felles med danskene. 
Når en nordmenn snakker med svensker, er det derfor stort sett bare en del «særsvenske» ord som er problemet; sjølve uttalen er stort sett ikke noe problem. I samtale med dansker er det omvendt; her er orda stort sett de samme som på norsk, men den danske uttalen er så forskjellig at kommunikasjonen her likevel er vanskeligere for de fleste.

Sett fra dansk synspunkt lyder norsk og svensk så likt at de fleste dansker ikke er i stand til å høre forskjell. Vanligvis trur danskene derfor at det er svensk også når de hører norsk - dersom de ikke hører forskjell, har de jo dobbelt så stor sjanse for å treffe riktig når de gjetter på svensk, fordi det er dobbelt så mange svensker i verden som nordmenn ...

Likevel viser begge undersøkelsene at dansker faktisk forstår norsk merkbart bedre enn svensk, sjøl om de ikke kan høre forskjell. Dette skyldes naturligvis det store glosefellesskapet mellom norsk og dansk. Litt uhøytidelig uttrykt kan vi dermed si at fra dansk synspunkt er en nordmann en svenske som er lett å forstå! Dermed er det også naturlig at svensker og dansker har størst problemer med å forstå hverandre språklig, for her er det en god del forskjeller både i ordforråd og uttale, mens nordmennene som nevnt havner i en gunstig mellomposisjon med «dansk» ordforråd og «svensk» uttale.

Men det fins enda et moment i tillegg til den reint språklige avstanden til nabospråka som kan forklare at nordmennene kommer så gunstig ut. Som vi har vært inne på flere ganger, blir de lokale dialektene brukt mye mer i Norge enn i nabolanda. Dette betyr at alle nordmenn er vant til å høre mange slags norsk i dagliglivet, mens dansker og svensker stort sett bare får høre ei eller høyst et par utgaver av morsmålet, nemlig riksspråket og eventuelt sin egen lokale dialekt. Dette kan også være en grunn til at dansker og svensker har mye lettere for å gi opp i nabospråkskommunikasjonen.

Det at nordmenn er så vant til språklig variasjon, både i skrift (bokmål og nynorsk) og spesielt i tale, gjør at de har et større passivt språklig repertoar enn de fleste dansker og svensker. Vi kan si det slik at for en nordmann er det å høre dansk eller svensk ikke noe vesentlig annerledes enn det å forstå en litt fjern norsk dialekt - det er uansett bare snakk om variasjon innafor det skandinaviske dialektkontinuumet. 


\section{Nabospråksforståelsen i fare?}

Fremdeles er sannsynligvis nabospråkskommunikasjon det normale når skandinaver møtes. Men nå ser det ut til at det å kommunisere på morsmålet med folk fra begge nabolanda snart vil kunne bli et eksklusivt norsk privilegium. På et nordisk språkmøte i år 2000 avla nemlig dansken professor Jørn Lund dette foruroligende vitnesbyrdet om hvordan stillinga er i dag:

Sønnen min har studert et semester

på University of British Columbia i

Vancouver. Innimellom slapper han av

med et par danske studiekamerater;

det er godt å kunne hvile i morsmålet,

å kunne uttrykke seg med alle nyanser, å forstå det underforståtte. I en e-post beskrev han den skandinaviske situasjonen slik: Norske og danske studenter bruker morsmålet seg imellom, svenske og norske gjør det også, men danske og svenske snakker engelsk.

Det professor Lund forteller om her, er riktignok det som kan skje når skandinaver møtes utenfor Norden, i reint engelskspråklige omgivelser. Men det fins også mange observasjoner som tyder på at det samme skjer når unge skandinaver fra forskjellige land møtes i Skandinavia.

Dersom engelsk skulle overta som lingua franca i muntlig samvær mellom skandinaver, ville et vesentlig element i den nordiske identiteten forsvinne. Og i så fall ville det nordiske språkområdet $i$ Skandinavia for første gang på to tusen år ikke lenger kunne oppfattes som et dialektkontinuum, men falle fra hverandre i forskjellige avstandsspråk.

Sett fra et nordisk synspunkt må et slikt framtidsscenario nærmest karakteriseres som ei kulturell katastrofe, og det er heldigvis heller ikke situasjonen pr. i dag. Det fins imidlertid som nevnt visse foruroligende tegn i tida som tyder på at det ville kunne bli det, dersom ikke skandinavene ser den verdien som ligger $\mathrm{i}$ å ha et fellesskap av over 20 millioner mennesker som kan kommunisere med hverandre ved hjelp av morsmålet - eventuelt supplert med visse justeringer i ordforråd og uttale dersom en merker at det kniper med forståelsen hos mottakeren. Med gjensidig respekt og interesse for språklige likheter og forskjeller bør vi dermed også i framtida kunne bevare Skandinavia som en språklig og kulturell enhet, der 
vi samtidig kan glede oss over et spennende mangfold. Dette vil kanskje også gjøre oss alle mer åpne og fordomsfrie overfor den nye multikulturelle situasjonen som møter oss i dagens samfunn.

\section{Litteratur}

Bandle, Oskar (hovedred.) (2002):

The Nordic Languages. Volume 1.

Berlin - New York. (Stort vitenskapelig oppslagsverk i to bind; andre bind kan ventes i 2005)

Braunmüller, Kurt (1998): De nordiske språk. Oslo. (Lærebok; opprinnelig skrevet på tysk for tyske studenter som leser nordiske språk)

Haugen, Einar (1976): The Scandinavian Languages. An introduction to their history. London. (Vitenskapelig oversiktsverk)

\author{
Karker, Allan, Birgitta Lindgren \& \\ Ståle Løland (red.) (1997): Nordens \\ språk. Oslo. (Relativt populært \\ skrevet oversiktsverk) \\ Torp, Arne (1998): Nordiske språk \\ i nordisk og germansk perspektiv. \\ Oslo. (Lærebok skrevet for norske \\ morsmålsstudenter på universitets- \\ nivå. Et kapittel av denne boka \\ ligger her: http://vestnorden.no/ \\ vestnord.doc) \\ Wessén, Elias (1965): De nordiska \\ språken. Stockholm. (Lærebok \\ skrevet for studenter som leser \\ nordiske språk)
}

\section{Internett}

Om nordisk språk-

samarbeid:

www.norden.org/sprak

Om skandinavisk nabo-

språksforståelse: $\quad$ www.nordkontakt.nu

Om «Vestnorden»: vestnorden.no

Om lingua franca:

Om pomorhandelen: www.uwm.edu/ corre/franca/edition2/lingua.2.html.

Om russenorsk: www.pomor.no

Om älvdalsk: www.kortlandt.nl/publications/art197e.pdf.

Om vestjysk: swedia.ling.umu.se/Svealand/Dalarna/Alvdalen

Om plattysk: www.statsbiblioteket.dk/dlh www.lowlands-I.net/talk/eng/index.php?page=lowsaxon www.rostra.dk/platt

Om frisisk: www.lowlands-l.net

Om sønderjysk: www.dialekt.dk www.jyskordbog.dk 



\section{KAISA HÄKKINEN}

\section{Finsk}

\section{Finsk og dets slektninger}

Finsk hører til den uralske språkfamilien, en spredt og splittet språkkjede som strekker seg fra Østersjøens strender helt til Jenisejfloden og Tajmyrhalvøya i Sibir. Benevnelsen uralske språk har været brukt helt siden begynnelsen av 1800-tallet og har sin årsak i at flertallet av disse språkene snakkes i nærheten av Uralfjellene, i grenseområdene mellom Asia og Europa. Språkfamiliens opprinnelige kjerneområde anses i dag for å ha vært enten i nærheten av Volgakroken eller i traktene i det nåværende Hviterussland.

Den uralske språkfamilien blir vanligvis delt inn i to hovedgrener. Den østlige grenen dannes av samojediske språk som snakkes i Sibir, og den vestlige grenen kalles den finsk-ugriske språkgruppen. Sistnevnte består i sin tur dels av de såkalte østersjøfinske språkene, dels av den ugriske grenen med de ob-ugriske språkene mansi og chanti, og deres nære slektning ungarsk. Ungarene bor i dag langt fra sine språklige slektninger, fordi deres forfedre vandret til Sentral-Europa sammen med tyrkiske stammer mot slutten av det første årtusenet etter Kristus. Andre finsk-ugriske språkgrener er samisk, de volgafinske språkene mordvinsk og mari og de permiske språkene komi og udmurtisk.

Til de østersjøfinske språkene hører i tillegg til finsk også karelsk, vepsisk, votisk, estisk og livisk. Disse språkene minner mye om hverandre når det gjelder både grammatisk struktur og ordforråd, selv om de ikke umiddelbart er innbyrdes forståelige, slik som de skandinaviske språkene. Likhetene skyldes i høy grad en lang felles historie. De uralske språkene rundt Østersjøen har utgjort en helhet, såkalt urfinsk, som dagens språk har utviklet seg fra. En eldre gren av urfinsk er ursamisk, mens en yngre gren er de østersjøfinske språkenes felles urspråk, såkalt yngre urfinsk. De viktigste trekkene i den grammatiske strukturen i finsk ble utviklet i løpet av den felles østersjøfinske perioden. 


\section{Finnenes forhistorie}

Finland er blitt befolket fra mange ulike hold, og der er blitt snakket mange forskjellige språk i Finland opp gjennom tidene. Det er i dag ikke mulig å finne ut når de første menneskene som snakket et uralsk språk, kom til landet, eller om de uralske forfedrene fantes blant de første innbyggerne. Senest på tretusentallet før Kristus anses det rådende språket $i$ det nåværende Finland å ha vært en form for tidlig urfinsk, fordi Finland på det tidspunkt var en del av det kamkeramiske kulturområdet som tradisjonelt er blitt assosiert med det uralske språkområdet.

I områdene rundt Østersjøen har finnenes forfedre som naboer hatt de indoeuropeiske folkene, som senere ble til baltere og germanere. De eldgamle kontaktene går tydeligst frem i ulike lag av lånord. Gamle baltiske lån er f.eks. halla 'frost', heinä 'høy' og ohra 'korn', og germanske lån er f.eks. kaura 'havre', pelto 'åker' (jf. svensk 'fält') og ruis 'rug'. Lånordene tyder på at de urfinske folkeslagene, som opprinnelig livnærte seg av fangst, lærte kvegdrift og jordbruk av sine baltiske og germanske naboer. At lagene av lånord er felles for alle de østersjøfinske språkene, viser at ordene er lånt inn før finsk var utviklet til et eget språk.

\section{Finske dialekter}

De finske dialektene deles inn i to hovedgrupper, østfinske og vestfinske dialekter. Grensen mellom de vestfinske og de østfinske dialektene følger stort sett den landegrensen som ble trukket opp mellom Sverige og Russland ved freden i Nöteborg i 1323. Ved den fredsslutningen ble Finland offisielt en del av det svenske riket. Forskjellen mellom de vestfinske og de østfinske dialektene har imidlertid sine røtter betydelig dypere og i forhistorisk tid.

I steinalderen bodde det neppe mer enn noen tusen mennesker i det nåværende Finland, og en så liten befolkning kunne naturligvis ikke bosette seg jevnt utover hele landet. Menneskene livnærte seg av jakt, av å fiske og sanke, og de søkte ved behov nye boplasser der de kunne finne mat. Fast bosetting oppsto mot slutten av steinalderen da man lærte å holde husdyr og dyrke jorda. De beste områdene for de nye næringene var i det vestlige Satakunta, Tavastland 
(på finsk Häme), sørvest i Finland («Det egentlige Finland», på finsk Varsinais-Suomi), og i øst Karelen (Karjala). På den måten oppsto etter hvert tre hoveddialektområder: Finland, Tavastland og Karelen.

Både det finske navnet Suomi og det svenske navnet Finland gjaldt fra begynnelsen bare den sydvestlige delen av landet, som fra 1800-tallet også ble kalt «Det egentlige Finland». De sørvestfinske og tavastlandske dialektene har i hvert fall delvis samme opprinnelse og representerer de vestfinske dialektenes eldste lag. Ut fra disse har de østerbotniske dialektene utviklet seg, i og med at den faste bosettingen spredte seg til Österbotten. Dialektene i nord er mer blandet ved at befolkningen der delvis også stammer fra ØstFinland. Siden det ikke fantes noen ordentlig grense mellom Finland og Sverige, spredte den finske bosettingen seg imidlertid også til Tornedalen og Västerbotten i det nåværende Sverige. Den tornedalsfinske dialekten utviklet seg deretter i kontakten med svensk til det som i dag kalles meänkieli ('vårt språk'), som har offisiell minoritetsspråksstatus i Sverige. De østfinske dialektene har hovedsakelig sitt utgangspunkt i oldtidskarelsk, selv om savolaxdialektene også synes å ha enkelte vestlige trekk.

Splittelsen i dialekter skjedde i en tid hvor de fleste i Finland levde av landbruk og hele sitt liv bodde og arbeidet i hovedsak i samme bygd. Situasjonen begynte å endre seg radikalt $i$ andre halvdel av 1800-tallet. Da bygde man jernbaner og store industrianlegg, og folk tok jobb som arbeidere og flyttet fra sted til sted for å finne arbeid. På 1900-tallet har dialektgrensene blitt stadig mer utydelige i takt med de økende flyttestrømmene. I løpet av annen verdenskrig ble over 400000 personer evakuert fra Karelen til andre deler av Finland. I 1960- og 1970-årene begynte en ny kraftig flyttebevegelse fra bygd til by, og særlig fra Savolax og Österbotten flyttet mange mennesker til Helsingfors-regionen. Helsingfors var helt frem til siste delen av 1800-tallet en praktisk talt helt svenskspråklig by, men i løpet av 1900-tallet utviklet byen seg til det etter folkemengden største, om enn språklig uensartede finske «dialektområdet». Også flyttebevegelsen fra Finland til Sverige var livlig til samme tid. De som flyttet, oppga som regel de mest markante trekkene i sine hjemlige dialekter, og de gamle bygdedialektene har mer og mer veket til side for allmennfinske talespråksformer. 


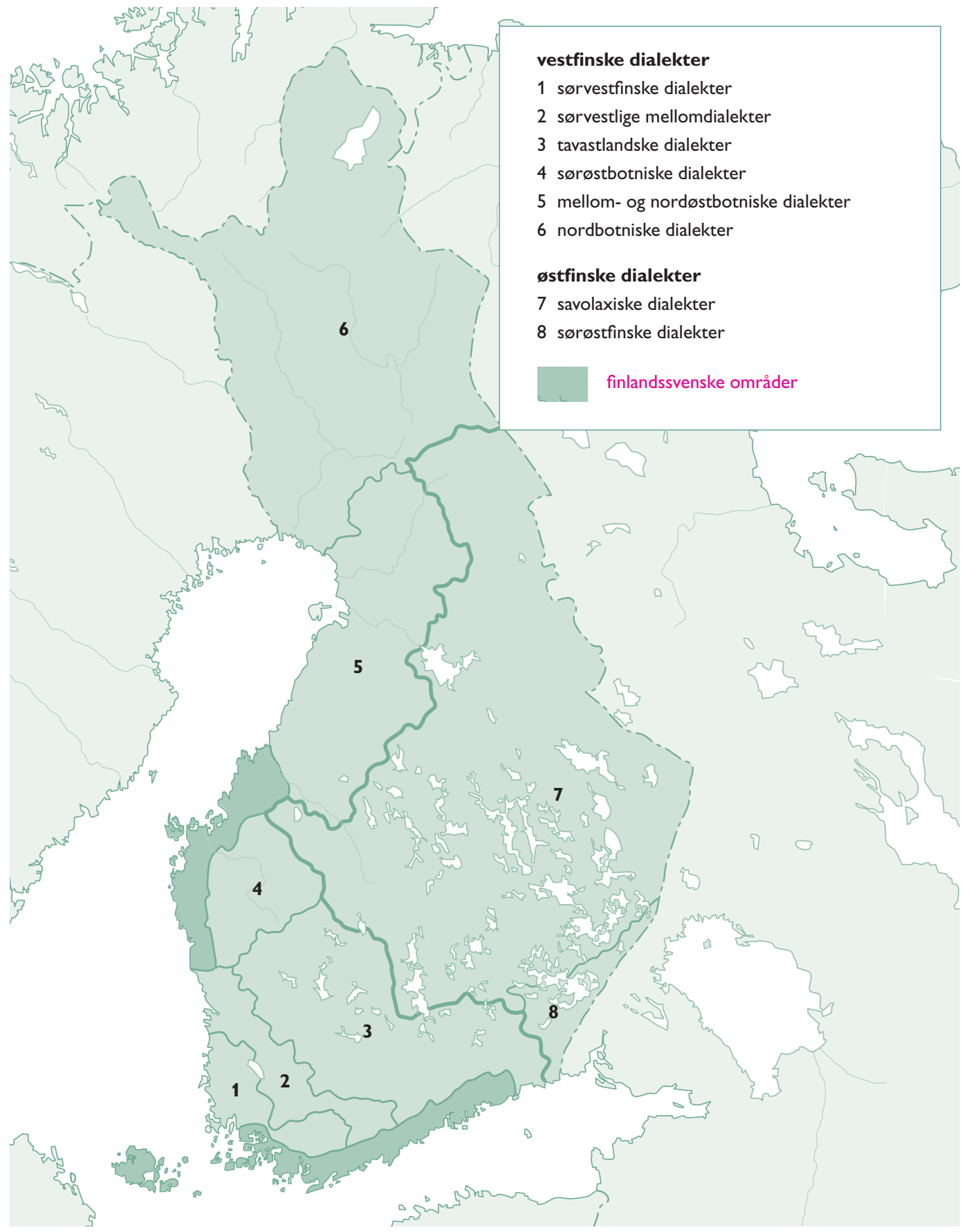




\section{Faser i det finske språkets historie}

\section{Oldtidsfinsk og middelalderfinsk}

Det finske språkets historiske utvikling etter urfinsk tid kan deles inn i fem perioder. Oldtidsfinsk representerer den eldste språkfasen i vår tidsregnings første årtusen. Allerede den gang ble grunnen lagt til dialektoppdelingen. I den neste, kulturhistorisk sett meget viktige, fasen var språket middelalderfinsk. Middelalderen regnes i Finland fra ca. 1150, som også de eldste historiske dokumentene om finske forhold stammer fra. Finland ble i løpet av middelalderen en del av det svenske riket, og underlagt svensk lov og administrasjonsskikk. Finsk hadde ikke noen offisiell stilling som lov- og forvaltningsspråk, men av praktiske grunner måtte finsk brukes i enkelte situasjoner. Finsk kom på den måten til å overta en rekke ord og uttrykk fra svensk lov- og forvaltningsspråk. F.eks. laamanni 'lagmann', laki 'lag' (lov) og tuomari 'domare' (dommer) er lån fra svensk.

De hedenske finnene ble i middelalderen omvendt til kristendommen både fra vest og fra øst. Den delen av Finland som kom under svensk styre, sluttet seg til den romersk-katolske kirken, og den ortodokse læren spredte seg i Karelen. Kristendommens utbredelse innebar store forandringer for finnenes verdensbilde og finsk ordforråd. Kirken hadde sine egne embeter og sitt eget utdannelsessystem, og også finnene hadde nå en mulighet til å gå den lærde veien. Det sentrale faget var latin, kirkens og hele den akademiske verdens fellesspråk i middelalderen. De fleste ordene det var behov for i kirkelivet, kom via svensk, f.eks. enkeli 'engel', kirkko 'kirke' og messu 'messe', mens en del kan ha kommet direkte fra latin, f.eks. epistola 'epistel', mammona 'mammon' og saatana 'satan'. 


\section{Gammel skriftfinsk}

Den tredje utviklingsfasen, som omfattet gammel skriftinsk, begynte i 1540-årene, da reformasjonen kom til Finland. Til reformasjonens prinsipper hørte at folket skulle få lov til å høre Guds ord på sitt eget morsmål, og dersom det ikke fantes noe skriftspråk fra før, måtte det lages nå. Mikael Agricola, som senere ble biskop i Åbo, oversatte og lot trykke de første finske bøkene. Den viktigste var Det nye testamente, som kom ut i 1548. Som hovedsakelig utgangspunkt for skriftspråket tok Agricola dialektene i Åbo-trakten, fordi Åbo var hovedstad og sentrum for kirkelivet. Men han utnyttet også språktrekk i de andre dialektene i den utstrekning det var nødvendig for å supplere Åbo-dialektenes uttrykksmuligheter.

Hele Bibelen ble oversatt til finsk i 1642, og den fungerte som mønster for skriftspråket helt til begynnelsen av 1800-tallet. På denne tiden var litteraturen i hovedsak religiøs. De sørvestfinske dialektene rådet fra nå av grunnen, men skriftspråket fikk også impulser fra de østerbotniske og tavastlandske dialektene.

\section{Eldre nåfinsk}

En ny fase i det finske språkets historie representeres av eldre nåfinsk, som kom på 1800-tallet. Sverige tapte Finland til Russland i 1809, og Finland ble et autonomt storfyrstedømme under Russland. Forvaltningsspråket forble svensk, men det ble stilt stadig mer bestemte krav om at det finske språkets stilling måtte styrkes. Også språket i seg selv ble gjenstand for oppmerksomhet på en helt annen måte enn tidligere. De vestlige dialektene ble ansett for å ha blitt ødelagt gjennom den sterke innflytelsen fra svensk, og modeller for skriftspråket ble nå lett etter i de «renere» østlige dialektene. De østlige dialektenes popularitet ble også styrket av nasjonaleposet Kalevala (1835), som Elias Lönnrot hadde sammenstilt fra folkediktning som han hadde samlet inn hovedsakelig i Karelen. Man begynte målbevisst å utvikle finsk til et kulturspråk gjennom utgivelse av aviser, lærebøker, faglitteratur innen for forskjellige områder og skjønnlitteratur, og gjennom å skape nye ord (se avsnittet om ordforrådet). 
Selv om finsk som språk utviklet seg kraftig i løpet av 1800-tallet, var det først i siste halvpart av århundret at finsk fikk en sterkere offisiell posisjon. Keiser Alexander II sanksjonerte i 1863 en språkforskrift som tilsa at finsk skulle sidestilles med svensk «i alt slikt som umiddelbart berører den egentlige finske befolkningen». Det første finskspråklige gymnaset ble grunnlagt i Jyväskylä i 1858, og det finskspråklige folkeskolevesenet begynte virksomheten i 1866 . Takket være det finske skolesystemet kom det flere finske studenter til universitetet, og på den måten ble det utdannet stadig flere funksjonærer med finsk som morsmål. Allerede i 1880-årene var det finske språkets språklige utvikling og samfunnsmessige stilling så mye utviklet at det gikk an å benytte finsk i nesten alle situasjoner og på alle livsområder. Enkelte unntak fantes allikevel. For eksempel forble de høyeste rettsinstansene svenskspråklige helt inn på 1900-tallet, og ved universitetet i Helsingfors, landets eneste universitet i begynnelsen av 1900-tallet, beholdt svensk sin stilling som hovedspråk for forskning og undervisning helt frem til 1930-årene.

\section{Nåfinsk}

Det finske språkets femte utviklingsfase med nåfinsk regnes fra 1880-årene og fremover. Etter denne fasen har ingen radikale forandringer skjedd når det gjelder det finske språkets struktur, men utviklingen har skjedd langsomt og i takt med forandringene i omverdenen. Derimot har språkbruk og holdningen til språket endret seg nye. På slutten av 1800-tallet og i første halvpart av 1900-tallet ble idealet for et dannet menneske ansett for å være at vedkommende i alle situasjoner snakket $\mathrm{i}$ henhold til skriftspråkets normer. I dag er holdningen en annen. I formelle situasjoner snakker man fortsatt standardspråk, men i mer uformelle sammenhenger brukes et friere talespråk eller sågar dialekt. Lignende tendenser finnes i det skrevne språket. For eksempel i skjønnlitteraturen forekommer ofte islett av dagligtale eller slang.

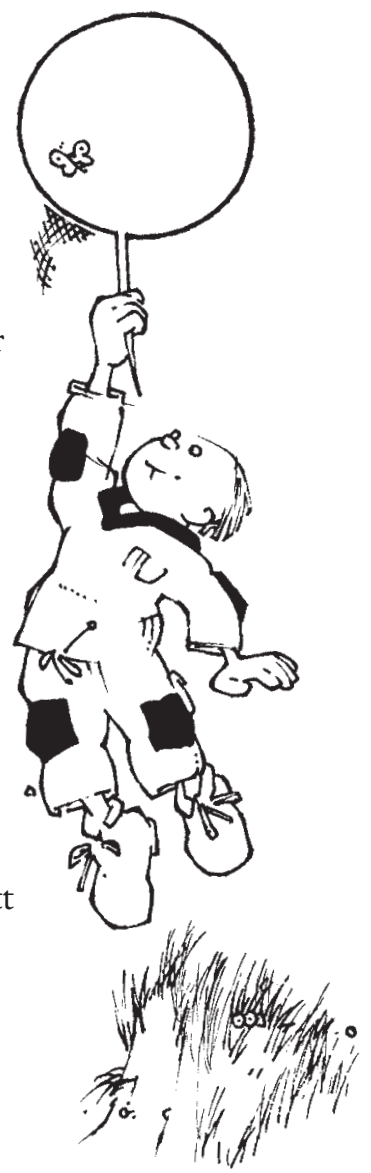




\section{Lydstruktur i nåfinsk}

Lydstrukturen i finsk karakteriseres av et mangfold vokaler og relativt få konsonanter. Det er åtte vokaler, og de kan deles inn i tre grupper etter hvordan de kan kombineres med hverandre:

\begin{tabular}{ll} 
fremre vokaler & $y$, ä, ö \\
\hline nøytrale vokaler & e, i \\
\hline bakre vokaler & $\mathrm{a}, \mathrm{o}, \mathrm{u}$
\end{tabular}

Med unntak av nyere lånord og sammensatte ord kan finske ord ikke samtidig inneholde både fremre og bakre vokaler. Fremre og bakre vokaler kan kombineres bare innbyrdes, og med de nøytrale vokalene (som rent fonetisk er fremre vokaler): talo 'hus', pyhä 'hellig', leima 'stempel', seinä 'vegg'. Denne kombinasjonsregelen kalles vokalharmoni. Ord av fremmed opprinnelse som bryter mot vokalharmonien, uttales ofte feil av finnene, på grunn av volkalharmoniens regler. For eksempel uttales olympia «olumppia».

I opprinnelige finske ord er det bare 13 konsonanter, men gjennom innflytelsen fra nyere lånord er konsonantsystemet $i$ dag mer omfattende. I tabellen nedenfor er konsonanter av fremmed opprinnelse ( $\mathrm{b}, \mathrm{f}, \mathrm{s}$, g) skrevet i kursiv:

\begin{tabular}{llll}
\hline plosiver & $\mathrm{p}, \mathrm{b}$ & $\mathrm{t}, \mathrm{d}$ & $\mathrm{k}, \mathrm{g}$ \\
\hline frikativer & $\mathrm{f}$ & $\mathrm{s}, \breve{s}$ & $\mathrm{~h}$ \\
\hline halvvokaler & $\mathrm{v}$ & & $\mathrm{j}$ \\
\hline likvider & $\mathrm{l}, \mathrm{r}$ & & \\
\hline nasaler & $\mathrm{m}$ & $\mathrm{n}$ & $\eta$ \\
\hline
\end{tabular}


Selv om finsk i utgangspunktet skrives som det uttales, tilsvarer språklydene og bokstavene ikke helt hverandre. Det finske alfabetet inkluderer også et antall fremmede bokstaver $(c, q, w, x, z, \stackrel{a}{a})$ som bare trengs for å skrive navn og ord på fremmede språk. På den annen side har $\mathrm{y}$-lyden ingen egen bokstav, men skrives som på de fleste andre språk som $n$ (f.eks. lanka [lanka]) eller $n g$ (kangas [kaynas]).

Nesten alle språklydene i finsk kan opptre både som korte og lange. Unntak er konsonantene $d, v, j$ og $h$. I dialektene kan også $v$, $j$ og $h$ uttales som lange. Derimot forekommer $d$ ikke i det hele tatt i de genuine dialektene. Hvordan $d$ er kommet inn i skriftspråket, forklares kort senere.

Lydlengde eller kvantitet har i finsk en viktig betydningsskillende funksjon. Kvantiteten er ikke avhengig av betoning eller stavelsesstruktur, men den er en selvstendig egenskap som må tas nøye hensyn til i skrift og uttale. Hovedtrykket i et finsk ord ligger alltid på første stavelse. En skandinav som begynner å lære finsk, vil med stor sannsynlighet gjøre uttale- og skrivefeil nettopp i forbindelse med kvantiteten. Her er eksempler på hvordan kvantiteten innvirker på betydningen:

\begin{tabular}{ll}
\hline tule & kom \\
\hline tulee & kommer \\
\hline (ei) tuule & blåser (ikke) \\
\hline tuulee & blåser \\
\hline tullee & kommer nok \\
\hline tuullee & blåser nok \\
\hline kansa & folk \\
\hline kanssa & sammen med \\
\hline
\end{tabular}


Finske ord inneholder i gjennomsnitt omtrent like mange vokaler som konsonanter. Stavelsens kjerne består av en vokal eller en diftong, dvs. en kombinasjon av to vokaler. Alle vokaler kan danne en diftong sammen med $i$ (ai, ei, oi, ui, yi, äi, öi) og etter vokalharmo-

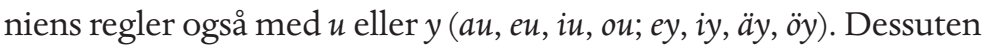
er det tre såkalte stigende diftonger: $i e, u o, y o ̈$. Disse har oppstått av lange vokaler $\left({ }^{\star} e e,{ }^{\star} o o,{ }^{\star} \ddot{o} \ddot{)}\right)$, og deres historiske bakgrunn kommer til syne ved lydvekslinger i forbindelse med ordbøyning: tie 'vei' : teissä, suo 'kjerr' : soissa, työ 'arbeid' : töissä.

I finske ord er det ti ulike stavelsestyper: $\mathrm{KV}, \mathrm{KVV}, \mathrm{KVK}, \mathrm{KVVK}$, KVKK, V, VK, VV, VVK, VKK ( $=$ konsonant, $\mathrm{v}=$ vokal). De vanligste typene er $\mathrm{KV}$ og KVK. Gamle finske ordstammer har ofte to stavelser og slutter på vokal. For eksempel ka-la 'fisk' og jal-ka 'fot' representerer prototypiske finsk-ugriske ordstammer. Som listen over stavelsestyper viser, kan en rent finsk stavelse aldri begynne med mer enn én konsonant, og et ord kan som regel heller ikke slutte med mer enn én konsonant (jf. ranta av svensk strand). En enkel grunnregel er at stavelsesgrensen går foran hver kombinasjon av konsonant og vokal (-KV), f.eks. pos-ki 'kinn' og pis-tää 'stikke'. Stavelsesgrensen kan også falle mellom vokaler, som f.eks. i sa-no-a 'si' og mä-en (genitiv av mäki, 'bakke').

\section{Grunnleggende morfologiske trekk}

Det finske språkets morfologi (formlære) deles inn i to deler, ordbøyning og avledning. Gjennom avledning danner man nye ord, gjennom bøyning tilpasses eksisterende ord til sin funksjon i setningen. Både avledning og bøyning skjer i praksis ved at endelser føyes til ordets stamme. Vi kommer tilbake til avledningen i avsnittet om ordforrådet.

Den store mengden bøyningsformer er karakteristisk for alle uralske språk. I bøyningen av nomina (substantiv, adjektiv osv.) benyttes suffiks for å angi både numerus og ulike relasjoner. Det finske skriftspråket har 15 ulike kasusformer: 


\begin{tabular}{lll}
\hline & entall & flertall \\
\hline nominativ & jalka 'fot, ben' & jalat 'føtter, ben' \\
\hline genitiv & jalan & jalkojen \\
\hline akkusativ & jalan & jalat \\
\hline partitiv & jalkaa & jalkoja \\
\hline essiv & jalkana 'som fot' & jalkoina \\
\hline translativ & jalaksi 'til fot' & jaloiksi \\
\hline inessiv & jalassa 'i foten' & jaloissa \\
\hline elativ & jalasta 'ut av foten' & jaloista \\
\hline illativ & jalkaan 'inn i foten' & jalkoihin \\
\hline adessiv & jalalla 'på foten' & jaloilla \\
\hline ablativ & jalalta 'av foten' & jaloilta \\
\hline allativ & jalalle 'på foten' & jaloille \\
\hline abessiv & jalatta 'uten fot' & jaloitta \\
\hline komitativ & jalkoineen 'med sin fot' & jalkoineen \\
\hline instruktiv & jalan 'til fots' & jaloin \\
\hline Oversettelsene blir bare omtrentlige & \\
\hline
\end{tabular}

Ettersom bøyningssuffiksene må følge vokalharmonien, har mange suffiks en form med fremre vokaler og en form med bakre vokaler, f.eks. talo-ssa 'i huset' - kylä-ssä 'i landsbyen', kissa-lta 'av katten' hiire-ltä 'av musen'.

Ved hjelp av endelser kan man også angi eierskap. I finsk er det som i de skandinaviske språkene seks grammatiske personer, og alle har sitt eget såkalte possessivsuffiks:

\begin{tabular}{llll}
\hline entall & & flertall & \\
\hline kissa-ni & min katt & kissa-mme & vår katt \\
\hline kissa-si & din katt & kissa-nne & deres katt* \\
\hline (hänen) kissa-nsa & hans katt & (heidän) kissa-nsa & deres katt** \\
\hline
\end{tabular}

* nynorsk: dykkar katt ** nynorsk: deira katt 
Flertallsendelser, kasusendelser og possessivsuffiks kan benyttes samtidig, men de må føyes til ordstammen i en bestemt rekkefølge: først flertallsendelsen, deretter kasusendelsen og til sist possessivsuffikset:

\begin{tabular}{ll}
\hline kissa-lle-mme & 'kat-til-vor' = til vår katt \\
\hline kisso-i-lle-nne & 'katt-e-til-jeres' = til deres katter \\
\hline
\end{tabular}

Finsk har ingen artikler og heller ikke grammatisk genus. Også i dette tilfellet er det spørsmål om eldgamle særtrekk for de uralske språkene. Det finnes heller ikke særskilte pronomen for hannkjønn og hunkjønn. Det finske pronomenet hän tilsvarer både han og hun på norsk.

I verbbøyningen kan man ved hjelp av endelser skille mellom aktiv og passiv, ulike modus, tempus og person. Passiv i finsk er en slags ubestemt personform, som i prinsippet tilsvarer vår «det»passiv. Passiven har sin egen endelse og dessuten en egen personendelse, for eksempel:

\begin{tabular}{lll}
\hline aktiv & (hän) sanoo, (hän) sanoi & han sier/sa \\
\hline passiv & sano-ta-an, sano-tt-i-in & det sies, det ble sagt \\
\hline
\end{tabular}

Aktiven har ingen spesiell endelse, og den normale presensbøyningen $i$ aktiv har bare personendelser:

\begin{tabular}{llll}
\hline minä sano-n & jeg sier & me sano-mme & vi sier \\
\hline sinä sano-t & du sier & te sano-tte & dere sier \\
\hline hän sano-o & han/hun sier & he sano-vat & de sier \\
\hline
\end{tabular}

Finsk har fire modus:

\begin{tabular}{lll}
\hline indikativ & sinä sanot & du sier \\
\hline potensialis & sinä sanonet & du sier vel \\
\hline kondisjonalis & sinä sanoisit & du skulle si \\
\hline imperativ & sano! & si! \\
\hline
\end{tabular}


Det er også fire tempusformer:

\begin{tabular}{lll}
\hline presens & sinä sanot & du sier \\
\hline preteritum & sinä sanoit & du sa \\
\hline perfektum & sinä olet sanonut & du har sagt \\
\hline pluskvamperfektum & sinä olit sanonut & du hadde sagt \\
\hline
\end{tabular}

I likhet med bl.a. norsk har finsk ingen egentlig futurumsform, men presensformen brukes for å angi så vel nåtid som fremtid. Fremtid kan uttrykkes gjennom en konstruksjon med verbet tulla 'komme': sinä tulet sanomaan 'du kommer (til) å si'.

Ved siden av de finitte personendelsene har verbene også infinitte former. Disse deles inn i to hovedgrupper, infinitiver og partisipp. Finsk har fire infinitiver. Viktigst av dem er den første infinitivens kortere form, som er verbets grunnform og brukes som oppslagsord i ordbøker. Verbenes infinitte former kan i prinsippet bøyes i kasus, men det er bare enkelte kasusformer som brukes:

\begin{tabular}{lll}
\hline 1. infinitiv & sanoa, sanoakse(ni) & si, for å si \\
\hline 2. infinitiv & sanoessa, sanottaessa, sanoen & siende \\
\hline 3. infinitiv & $\begin{array}{l}\text { sanomalla, sanomassa, sanomasta, } \\
\text { sanomalla, sanomatta, sanoman, } \\
\text { sanottaman }\end{array}$ & \\
\hline 4. infinitiv & sanominen, sanomista & siende, å si \\
\hline
\end{tabular}

Den første infinitivens translativform (sanoakse[ni]) må alltid etterfølges av possessivsuffiks som angir person. Enkelte infinitiver kan brukes også i passiv (sanottaessa, sanottaman), men de fleste brukes bare i aktiv form. Infinitivene benyttes på mange ulike måter i setningen, bl.a. som del av ulike verbkjeder: minun täytyy sanoa 'jeg må si', olin juuri sanomassa 'jeg skulle akkurat til å si' ('jeg var akkurat siende'). 
Det er tre partisipp, og de to første har både aktiv og passiv form:

\begin{tabular}{lll}
\hline 1. partisipp & sanova, sanottava & siende \\
\hline 2. partisipp & sanonut, sanottu & sagt \\
\hline agentpartisipp & sanoma & sagt (av noen) \\
\hline
\end{tabular}

Partisippene brukes bl.a. som adjektiv, f.eks. naurava tyttö 'en smilende jente', oppinut mies 'en lærd mann' og i sammensatte verbformer, f.eks. hän oli sanonut 'han hadde sagt', se olkoon sanottu 'det må være sagt'. Agentpartisipp brukes når man vil angi hvem som har utført handlingen, f.eks. isän rakentama talo 'det av far bygde huset'; tämä talo on isän rakentama 'dette huset er bygd av far'.

Et eldgammelt særtrekk i de uralske språkene er at nektelsesordet er et verb, ikke et ord som ikke kan bøyes, som f.eks. vårt norske ikke. Nektelsesverbet bøyes i alle seks personer:

\begin{tabular}{ll}
\hline minä en sano & me emme sano \\
\hline sinä et sano & te ette sano \\
\hline hän ei sano & he eivät sano. \\
\hline
\end{tabular}

Nektelsesverbets bøyning er ikke like mangesidig som bøyningen av vanlige verb. Fortid og modus uttrykkes med ulike former hos hovedverbet og ved behov med hjelpeverbet olla 'være, ha'.

\begin{tabular}{ll}
\hline sinä et sano & du sier ikke \\
\hline sinä et sanonut & du sa ikke \\
\hline sinä et ole sanonut & du har ikke sagt \\
\hline sinä et ollut sanonut & du hadde ikke sagt \\
\hline sinä et sanoisi & du skulle ikke si \\
\hline sinä et sanone & du torde ikke si \\
\hline älä sano! & si ikke! \\
\hline
\end{tabular}


I de enkleste tilfellene er finske bøyningsendelser som klosser, som man ved behov kan sette etter hverandre i en bestemt rekkefølge etter ordets stamme. Det finnes for så vidt mange ulike endelser, men de lar seg lett isolere og gjenkjenne. Det som gjør det vanskelig å lære bøyningssystemet, er at det i noen tilfeller blir lydveksling når man kombinerer ordstammer og endelser. Vekslingene skyldes lydendringer som er skjedd tidligere, og som bare blir realisert $\mathrm{i}$ enkelte fonetiske omgivelser.

Mange lydendringer skyldes den såkalte stadievekslingen. Denne påvirker plosivene $p, t$ og $k$, som i enkelte omgivelser er blitt svekket og har endret kvalitet eller blitt borte helt. Stadievekslingen kan f.eks. gi seg følgende uttrykk:

\begin{tabular}{llll}
\hline tupa : tuvan & hytte & kampa : kamman & kam \\
\hline pata $:$ padan & gryte & ranta : rannan & strand \\
\hline sika $:$ sian & svin & kenkä : kengän & sko \\
\hline
\end{tabular}

Også de lange plosivene pp, $\mathrm{tt}, \mathrm{kk}$ blir utsatt for stadieveksling, som her blir realisert som forkortelse:

\begin{tabular}{ll}
\hline nappi : napin & knapp \\
\hline tyttö : tytön & jente \\
\hline tukki : tukin & tømmerstokk \\
\hline
\end{tabular}

Eksemplene illustrerer også den opprinnelige årsaken til stadievekslingen: Klusilen mellom den første og den andre stavelsen er svekket når den andre stavelsen er lukket, det vil si slutter på en konsonant. I dagens finsk følger stadievekslingen ikke alltid denne regelen, fordi ordenes struktur er forandret på mange andre måter.

Stadievekslingen forklarer også tilblivelsen av konsonanten $d$. Opprinnelig har det «svake» motstykket til $t$ vært den stemte frikativen $d$ (jf. islandsk $\partial$ og den danske uttalen av $d$ i f.eks. vid). Ettersom frikativen ikke har hatt noen egen bokstav, er den blitt skrevet som $d$, som deretter har blitt uttalt som den stemte plosiven $d$, slik som i andre vekslingsmønster. I dialektene har $₫$ forandret seg på 
andre måter. Den tilsvares i de vestfinske dialektene av $r$ eller $l$ (pata : paran eller palan 'gryte'), men i de østfinske dialektene er den blitt borte (pata : paan).

\section{Hovedtrekk i syntaksen (setningslæren)}

Slik som i de skandinaviske språkene er den normale ordstillingen i finsk subjekt - verbal - objekt, f.eks. poika heittää pallon 'gutten kaster ballen'. I motsetning til de skandinaviske språkene beholder finsk denne ordstillingen også når setningen begynner med et adverb: nyt poika heittää pallon ('nå gutten kaster ballen'), dvs. 'nå kaster gutten ballen'. Ordstillingen kan varieres for å skape spesielle effekter, f.eks. emfase eller motsetning: pallon heittää poika innebærer f.eks. at det er gutten og ikke jenta som kaster ballen (på norsk kan dette også uttrykkes med passiv: ballen kastes av gutten). Ordstillingen kan også brukes for å uttrykke bestemthet, dvs. at noe er kjent fra før (finsk skiller for øvrig ikke mellom bestemt og ubestemt form, og poika kan være både en gutt og gutten): poika istuu pöydällä 'gutten sitter på bordet', pöydällä istuu poika 'på bordet sitter en gutt' = 'det sitter en gutt på bordet'.

For noen typer av setninger finnes spesielle konstruksjoner. En slik er konstruksjonen for eierskap: pojalla on pallo 'gutten har en ball' (ordrett: 'hos gutten er en ball'). Her er det det som eies, dvs.

ballen, som er grammatisk subjekt, mens eieren uttrykkes som et adverbial med substantivet $\mathrm{i}$ kasus adessiv.

Tvang eller forpliktelse uttrykkes med spesielle såkalte necessive konstruksjoner. F.eks. 'gutten må gå’ kan på finsk være pojan täytyy mennä (ordrett omtrent 'for gutten er nødt til å gå), pojan on mentävä eller noe alderdommelig pojan on meneminen (de to sistnevnte omtrent: 'gutten har å gå’). Subjekt i de skandinaviske språkene tilsvares i disse konstruksjonene av et ord i genitiv.

Rundt verbenes infinitiver og partisipp kan man konstruere såkalte setningsmotstykker som i betydning tilsvarer bisetninger. Med kasusendelser og possessivsuffiks kan man uttrykke tid og person: f.eks. tultu-a-ni ('komm-et-etter-min'), som betyr 'etter at jeg var kommet'. 
Det finske språkets syntaks blir styrt av strenge kongruensregler, og setningsdelene påvirker hverandres form. Kongruens er et eldgammelt trekk i de uralske språkene. Kongruens mellom subjekt og verbal innebærer f.eks. at verbets numerus og personform er avhengig av subjektets person (se avsnittet ovenfor).

I finsk i dag, akkurat som i de nærbeslektede østersjøfinske språkene, står pronomenattributt og adjektivattributt i samme numerus og kasus som hovedordet:

\begin{tabular}{ll}
\hline tämä pieni talo & dette lille hus \\
\hline tässä pienessä talossa & i dette lille hus \\
\hline tähän pieneen taloon & inn i dette lille hus - osv. \\
\hline
\end{tabular}

Tilsvarende kongruens råder mellom telleord og hovedord: kolme pientä poikaa 'tre små gutter' : kolmelle pienelle pojalle 'til de tre små guttene'. Spesielt for denne konstruksjonen er at hovedordet står i entall etter et telleord, til tross for at det dreier seg om flere individer (jf. näille pienille pojille 'til disse små gutter').

I de indoeuropeiske språkene uttrykkes relasjonene mellom ordene ofte med preposisjoner. I finsk og de beslektede språkene var det fra gammelt av ikke noen preposisjoner, men man brukte i stedet postposisjoner og kasusformer. Også i dag brukes en hel del postposisjoner i finsk, f.eks. talon edessä 'foran huset', talon takana 'bak huset', talon alla 'under huset'. Enkelte postposisjoner kan også - etter modell fra svensk og andre fremmedspråk - brukes som preposisjoner: aidan yli eller yli aidan 'over gjerdet', läpi seinän eller seinän läpi 'gjennom veggen'.

\section{Ordforrådet}

Ordene i finsk kan etter sin struktur deles inn i tre hovedtyper: enkle grunnord som kala 'fisk' og pesä 'bo', ord som er avledet, som kalastaa 'fiske' og pesiä 'hekke, bygge bo', og sammensatte ord som kalakauppa 'fiskebutikk' og linnunpesä 'fuglerede'. De enkle grunnordene danner stammen i ordforrådet, og en del av dem er eld- 
gamle uralske arveord. F.eks. kala og pesä har eksistert helt siden det uralske urspråket, og de er uforandret bevart i de flere tusen årene som er gått siden den gang.

Nye ord kan dannes hovedsakelig gjennom avledning, sammensetning eller lån fra andre språk. Alle disse måtene er utnyttet så langt det finske ordforrådets utvikling kan følges bakover i tid. Gjennom sammensetning har man fremfor alt dannet nye substantiver, mens avledning er benyttet for å danne ord av alle ordklasser. Gjennom avledning kan man bytte ordklasse og f.eks. danne verb av substantiver ( $k \ddot{a} s i$ 'hånd' $\rightarrow$ käsitellä 'behandle, håndtere') eller substantiver av verb (maksaa 'betale' $\rightarrow$ maksu 'betaling'). Fra samme stamme kan man sette opp flere avledningssuffiks (käsiteltävyys 'håndterbarhet').

Som eksempel på muligheten til å danne ord gjennom avledning kan vi ta utgangspunkt i ordet kirja 'bok'. Ordet har opprinnelig betydd tegn eller ornament (jf. kirjava 'brokete' i dagens finsk):

\begin{tabular}{ll|ll}
\hline kirja & bok & kirjelmöinti & skriveri \\
kirjanen & brosjyre, småskrift & kirjoite & skrift, utskrift \\
kirjailla & forfatte & kirje & brev \\
& (også: brodere) & kirjuri & skriver (menneske) \\
kirjailija & forfatter & kirjoitin & skriver (for pc) \\
kirjailu & skriveri & kirjoittautua & skrive seg inn \\
& (også: broderi) & kirjoittautuminen & innskrivning \\
kirjasto & bibliotek & kirjain & bokstav \\
kirjoittaa & skrive & kirjaimellinen & bokstavelig \\
kirjoitus & skrivning & kirjaimisto & alfabet \\
kirjoituttaa & la skrive & kirjake & type \\
kirjoittaja & skribent & kirjasin & type, stil \\
kirjoitella & (holde på å) skrive & kirjata & bokføre, registrere \\
kirjoitelma & skrift, artikkel & kirjaaja & registrator \\
kirjoittelu & skrivende, skriveri & kirjaamo & registreringskontor \\
kirjallinen & skriftlig, litterær & kirjaus & bokføring, \\
kirjallisuus & litteratur & & registrering \\
kirjelmä & skrift & kirjauttaa & la bokføre/ \\
kirjelmöidä & sette sammen en skrift & & registrere \\
& & & \\
\hline
\end{tabular}


Sammensetninger kan i finsk være betydelig lengre enn i mange andre språk, og det er ingen absolutt grense for hvor mange ledd en slik sammensetning kan ha. F.eks. kaksisataaviisikymmenvuotisjuhlakilpapurjehdus (ordrett 'tohundreogfemtiårsjubileumskonkurranseseilas') inneholder åtte ord, hvorav to er avledninger (vuotis- 'års-', purjehdus 'seilas'), mens de øvrige er enkle grunnord.

Av de enkle grunnordene i finsk er ca. halvparten opprinnelige uralske ord og halvparten lånord. Den eldste lånordtypen består av eldgamle indoeuropeiske lån, hvorav enkelte stammer fra det indoeuropeiske urspråket (mehiläinen 'bi', mesi 'honning, nimi 'navn', vesi 'vann'), andre fra den indoiranske språkgrenen (jumala 'gud', orja 'slave', sata 'hundre', vasara 'hammer'). Lånene viser at de uralske folkene alltid har levd i naboskap med de indoeuropeiske, hvis urhjem etter flere forskeres oppfatning har vært i områdene nord for Svartehavet.

I Østersjø-området ble det i urfinsk tid lånt inn ord fra de baltiske språkene (heinä 'høy', ratas 'hjul') og fra de germanske språkene (kuningas 'konge', ruhtinas 'fyrste' (germ. druhtinaz, jf. skand. drott, isl. dróttinn), sairas 'syk' (germ. sairaz, jf. skand. sår), siima 'tau, line', jf. isl. simi 'telefon').

Senere har finsk som eget språk fått lån fra russisk (pakana 'hedning', saapas 'støvel') og særlig fra svensk. Finsk har jo i nesten tusen år levd side om side med svensk, og svensk er fortsatt Finlands andre nasjonalspråk. Ikke minst er slikt som har med næring, mat, klær, bygging, utdannelse, samfunnsliv og kultur å gjøre, blitt kjent i Finland gjennom det svenske språkets formidling, og ordene er derfor også ofte lånt fra svensk. Man har beregnet at det er minst 4000 lånord fra svensk i det finske språket, men de svenske lånene er ikke undersøkt i detalj, og det faktiske antallet er antagelig vesentlig høyere. Dessuten er det en rekke såkalte oversettelseslån som puutarha 'hage' (= trädgård) (puu = tre, tarha = gård; jf. dk. have, no. hage) og peruskoulu 'grunnskole'. Selv om finsk og svensk overhodet ikke hører til samme språkfamilie, har kontaktene mellom språkene vært så intensive i historisk tid at begrepssystemene i de to språkene har mer til felles enn begrepssystemene i mange nærbeslektede språk. Også svensk har lånt noen ord fra finsk f.eks. pojke (no. gutt og fi. poika) og känga (no. støvel og fi. kenkä ’sko'). 
Lånene fra svensk er på ulike måter tilpasset finsk lydstruktur. Konsonantgrupper i begynnelsen av ordet er forenklet, stemte plosiver er blitt ustemte, lang $f$ er blitt $h v$, og en vokal er lagt til på slutten. Slik har f.eks. dans, dragon, giraff, stolpe og strand blitt tanssi, rakuuna, kirahvi, tolppa og ranta.

I finsk er det også et ganske stort antall internasjonale lånord som gjenfinnes i de fleste europeiske språk, f.eks. filosofia, professori, skandaali. Det er ofte vanskelig å si fra hvilket språk de er lånt inn, men særlig de eldre lånene har normalt kommet via svensk. Fremfor alt på 1800-tallet, men også senere har man bevisst forsøkt å unngå fremmede ord og i stedet skapt egne erstatningsord. Mange vitenskaper har f.eks. både internasjonale og rent finske navn: juridiikka-oikeustiede (jf. rettsvitenskap), psykologia-sielutiede (ordrett "sjelsvitenskap»). Det finske ordet for telefon er puhelin (av puhua 'tale'). I den siste tiden har ikke lånordene vært motarbeidet på samme måte, men hvis gode og helt finske erstatningsord finnes, pleier de å slå an (f.eks. palvelin 'server' av palvella 'betjene').

\section{Finsk i dag og i morgen}

Finsk snakkes i dag av ca. fem millioner mennesker, og språkets stilling er sterkere enn noen gang. Finsk kan i dag brukes i Finland i alle tenkelige situasjoner, både formelt og uformelt. Da Finland ble medlem av EU, ble finsk også et av unionens offisielle språk. I Sverige har finsk status som offisielt anerkjent minoritetsspråk.

Ansvaret for finsk språkpleie og det finske standardspråkets utvikling ligger offisielt hos etaten «Forskningscentralen för de inhemska språken». Forskningscentralen gir svar på språkspørsmål, gir anbefalinger og publiserer ulike språklige håndbøker, en stor deskriptiv finsk grammatikk og ordbøker av ulike slag om både nåfinsk, gammel finsk og finske dialekter. Der finnes også omfattende språklige arkiver. I Sverige har «Sverigefinska språknämnden» ansvaret for det finske språket.

I dag diskuteres, særlig i Norden, om den økende bruken av engelsk utgjør en trussel mot våre egne språk. I denne konkurransesituasjonen er situasjonen ulik for ulike språk, men sterkest står de språkene som er offisielle i sitt land, som har et etablert og stabilt 
standardspråk, og som brukes som undervisningsspråk i skoler og universiteter. Finsk oppfyller i dag alle disse kriteriene. Språkets fremtid ligger i hvert fall i hendene på språkbrukerne selv. Språket kan bevares bare hvis språkbrukerne aktivt går inn for å bruke det og bevare det.

Oversettelse fra finsk til svensk: Mikael Reuter

Oversettelse fra svensk: Kari Styren

\section{Litteratur}

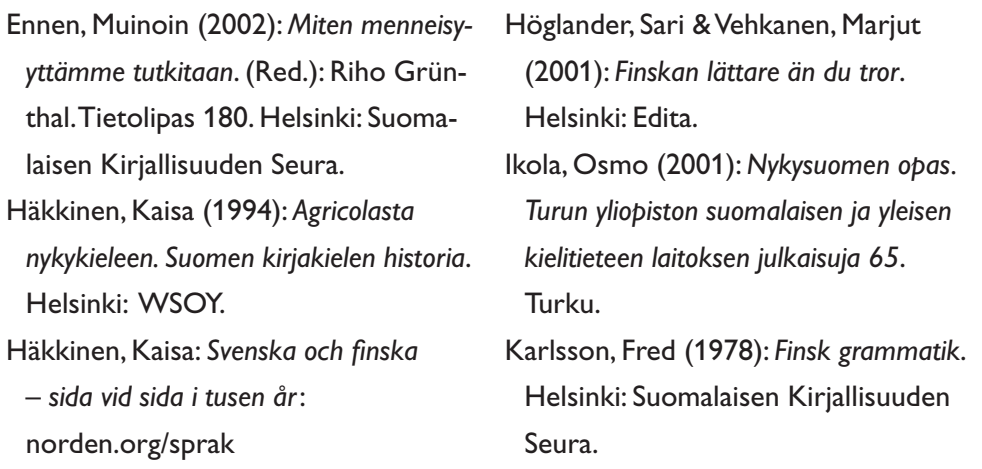

\section{Internett}

www.spraknamnden.se/sverigefinska.htm

virtual.finland.fi (Education \& Research - Language)

www.kotus.fi 



\section{Samiske språk}

\section{Det samiske bosettingsområdet og samiske språk}

De samiske bosettingsområdet, Sápmi, strekker seg fra østkysten av Kolahalvøya over Nord-Finland, via kyst- og innlandet i Norge og innlandet i Sverige, ned i Jämtland og til Idre (jf. kartet nedenfor). Sápmi består av ett sammenhengende geografisk område som i seg selv har gitt ulike typer av tradisjonelle næringer, bl.a. jakt og fiske, reindrift og jordbruk. Innenfor dette området snakkes flere samiske språk og dialekter.

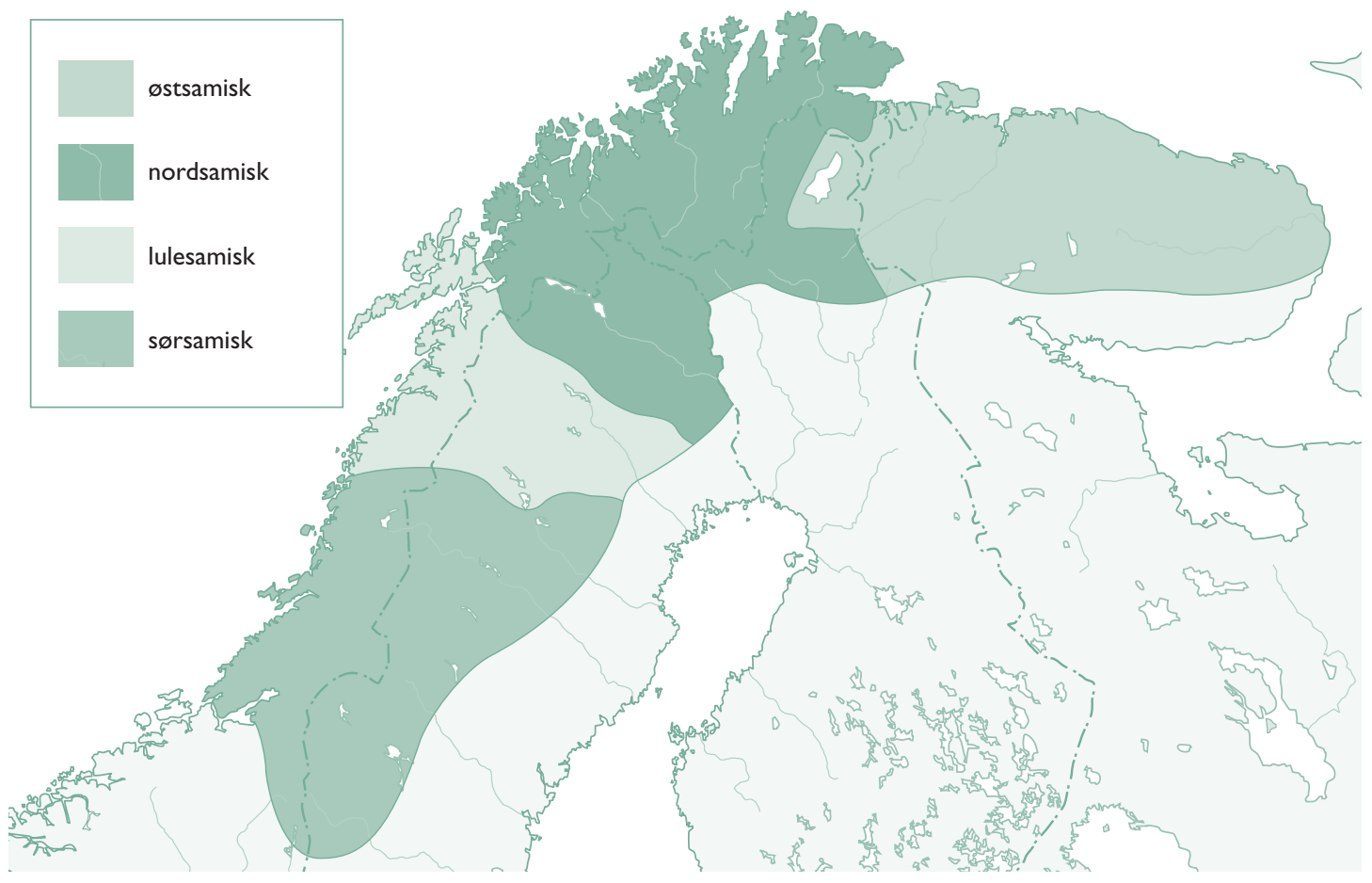

Figur 1: Det samiske bosettingsområdet, Sápmi 
De samiske språkene blir som regel delt inn i tre språkområder: østsamisk, sentralsamisk og sørsamisk. Ingen samisk språkgrense sammenfaller med noen landegrense.

Til de østsamiske språkene hører enaresamisk, som snakkes i Finland og rundt Enare träsk, og skoltsamisk, som snakkes i Finland og Russland. Andre språk som snakkes på Kolahalvøya, er kildinsamisk, akkalasamisk og tersamisk.

Sentralsamisk kan i sin tur deles inn i et nordsamisk og et lulesamisk område. Som nordsamisk regnes sjøsamisk, som snakkes i kystområdene i Norge, finnmarkssamisk, som snakkes i Finnmark (bl.a. Guovdageaidnu/Kautokeino og Kárášjohka/Karasjok) og i tilgrensende områder i Finland (bl.a. Ohcejohka/Utsjoki), samt tornesamisk som snakkes nord for Jiellevárri/Gällivare i Sverige og i tilgrensende områder i Finland og Norge. De øvrige sentralsamiske språkene er lulesamisk, som snakkes i Jåhkåmåhkke/Jokkmokk i Sverige og i Divtasvuodna/Tysfjord i Norge, samt arjeplogsamisk, som snakkes i Arjeplog-området.

Til de sørsamiske språkene hører umesamisk, som snakkes i Västerbotten i Sverige, og det egentlige sørsamisk som snakkes i søndre Västerbotten og i Jämtland i Sverige.

\section{Historiske kontakter}

Samene har bodd i Sápmi i flere tusen år og hadde lenge ingen særlig kontakt med andre folk. De første kontaktene med de skandinaviske folkeslagene oppsto for mer enn ett tusen år siden, mens kontaktene med andre finsk-ugriske folk, dvs. mennesker som snakket beslektede språk, eksisterte for mange tusen år siden og allerede før man kan snakke om samene som en etnisk gruppe.

Et språk bærer med seg kunnskaper om fortiden, om menneskene som snakket nettopp dette språket, og om hvordan de kan ha levd, og hvordan deres samfunnsliv kan ha sett ut. Ved å sammenligne den finsk-ugriske språkfamilien med andre språk innenfor den uralske språkætten, bl.a. de samojediske språkene, kan man trekke slutninger om samenes kontakt med andre folk opp gjennom historien og også om levemåten til samenes forfedre. Det språkforskerne gjør, er å rekonstruere oldtidsformer med utgangspunkt i nåtidens former, siden skriftlige kilder fra den tid naturligvis mangler. 


\section{Perioden fra år 4000 til år 2000 før vår tidsregning}

Det er ord i samisk som skriver seg fra mer enn 6000 år tilbake i tiden, f.eks. njuolla (pil), juoksa (bue), suotna (sene), guolli (fisk), njoammil (hare). Eksemplene er på nordsamisk. Disse ordene har en felles ordstamme med andre språk som hører til de uralske språkene - og samisk inneholder et hundretall slike ordstammer. Dette tyder på kontakt under forhistorisk tid med folk og folkegrupper østover til Uralfjellene (finsk-ugriske språk) og Vest-Sibir (samojediske språk).

Det er også mulig ut fra ordforrådet å ha hypoteser om når enkelte kontakter kan ha opphørt. Ord som f.eks. goahti (lavvo), liepma (buljong), njuovvat (slakte) og lohkat (regne eller lese) og opptil 150 andre ord tilhører en periode som kan ha begynt for ca. 6000 år siden, fordi disse ordene er felles blant dem som snakker finskugriske språk, men finnes ikke i de andre uralske språkene. Dette tyder på at de nære kontaktene med de gruppene som snakker samojediske språk, opphørte på denne tiden.

På samme måte kan man av ord som beana (hund), gáma (sko), reahpen (røykhull i lavvoen) og mádjit (bever) slutte seg til at den nære kontakten med ugriske språk, f.eks. ungarsk, opphørte for 5000 år siden.

I tillegg til kontakten med finsk-ugriske folk hadde samenes forfedre svært tidlig i historien også kontakt med folk som snakket indoeuropeiske språk. Til de indoeuropeiske språkene hører de fleste språkene i Europa, f.eks. germanske og romanske språk, så vel som baltiske og slaviske språk, og flere språk i Sør-Asia. Det finnes blant annet indoeuropeiske lånord i både uralske og finsk-ugriske språk, f.eks. suotna (sene), som tyder på kontakt mellom folkegruppene for mer enn 6000 år siden.

\section{Perioden fra år 2000 før vår tidsregning til år 1000}

Ifølge en bredt akseptert teori går de samiske og de østersjøfinske språkene, dvs. for eksempel finsk og estisk, tilbake til et felles samisk-finsk urspråk, som ble snakket for ca. 4000 år siden (eller enda tidligere). Ut fra dette språket utviklet ursamisk og urfinsk seg for ca. 3000 år siden. Samisk antas å ha vært temmelig enhetlig på denne tiden, for etter hvert å utvikle seg til de nåværende språk eller dialekter omkring år 800, dvs. for ca. 1200 år siden. 
I løpet av de siste årene er det lagt frem hypoteser om at i hvert fall sørsamisk ble atskilt fra de øvrige samiske språkene langt tidligere. Som støtte for dette angis at sørsamisk har flere alderdommelige trekk, f.eks. i kasusformene, og at språket har en mer innviklet vokalisme enn øvrige samiske språkene. I ordforrådet gjenfinnes også noen svært gamle (baltiske) lånord som ikke finnes i de øvrige samiske språkene.

Opp gjennom historien og i flere tusen år hadde samenes forfedre også kontakt med germanske folkegrupper, og flere ord er lånt inn, f.eks. bassi (hellig), dohppa (slire).

Det finnes også urnordiske lånord i samisk. Disse lånene antyder kulturkontakter som ble opprettet i de første århundrer etter vår tidsregning, og noen eksempler på dette er áiru (åre), gáica (geit), gussa (ku), vuostá (ost). Det er flere hundre slike lånord i samisk. Samene har også lånt flere hundre ord fra dem som snakket urfinsk, f.eks. bálká (lønn), boallu (knapp), dávda (sykdom), oastit (kjøpe).

Lånordene viser ikke bare hvilke kontakter samene har hatt i ulike perioder, men gir også en pekepinn om hvilke områder av samfunnslivet disse kontaktene gjaldt.

Til slutt kan nevnes at det er samiske lånord i vår tids svenske og norske språk, f.eks. svensk sarv (< sarvvis = 'reinsdyrokse') og svensk/norsk rajd/raide (<ráidu = '(reinsdyr)raid') og nåjd/naaide $(<$ noaidi $=$ 'samisk sjaman'). Mange termer innenfor reindrift er lånt inn fra finsk, særlig fra nordfinske dialekter, f.eks. urakka $(<$ varik $=$ 'hannrein i toårsalderen' $)$ og suopunki $(<$ suohpan $=$ 'lasso' $)$.

\section{Hvor mange snakker samisk?}

Det er ca. 60000 samer i Sápmi. Av disse bor ca. 35-40 000 i Norge, 6000 i Finland, 15-20 000 i Sverige og 2000 i Russland. Tallene er imidlertid usikre og bygger på vurderinger. Det finnes studier som tyder på at tallene er i underkant, og at langt flere har sine røtter i den samiske befolkningen, men at de kanskje ikke vet om det eller bryr seg om det. 
Man regner med at det finnes ca. 20000 samer som har kunnskap i et av de samiske språkene. De samiske språkene på Kolahalvøya er imidlertid alvorlig truet. Tersamisk og akkalasamisk snakkes av et fåtall eldre personer, trolig færre enn 30 personer, og risikerer å bli borte. Kildinsamisk er det språk som har flest brukere i området, 600-700 personer. Skoltsamisk snakkes kun av et 20-talls personer i Russland, de fleste som snakker skoltsamisk, bor i Finland. Av den samiske befolkningen på ca. 2000 personer i Russland har oppimot 35-40\% kunnskaper i samisk, i hovedsak kildinsamisk. Østsamiske språk som snakkes i Finland, er altså enaresamisk og skoltsamisk. Ca. 500 personer tilhører hver av disse to språkgruppene.

Nordsamisk snakkes både i Finland, Norge og Sverige av anslagsvis 16-18 000 personer, hvorav ca. 9-10 000 i Norge, 5-6000 i Sverige og ca. 2000 i Finland. Kanskje oppimot $85-90 \%$ av alle som snakker samisk, bruker nordsamisk.

Lulesamisk snakkes i Sverige og Norge av anslagsvis 800 personer, og i det tallet kan også brukerne av arjeplogsamisk inkluderes.

Umesamisk har også bare et fåtall eldre brukere og risikerer å bli borte, mens det egentlige sørsamiske språket fortsatt snakkes av 600-800 personer i Sverige og Norge.

\section{Oppbygningen av samisk}

\section{Bøyning av verb}

Samisk er et formrikt språk. Verbene bøyes etter subjektet og får dermed ni ulike former i presens, fordi samisk i tillegg til entall og flertall også har dualis (totall). Formene av borrat (spise) fremgår nedenfor. Alle eksemplene er hentet fra nordsamisk (saN).

\begin{tabular}{ll}
\hline (mon) boran & (jeg) spiser \\
\hline (don) borat & (du) spiser \\
\hline (son) borrá & (han/hun) spiser \\
\hline (moai) borre & (vi to) spiser \\
\hline (doai) borrabeahtti & (dere to) spiser \\
\hline (soai) borraba & (de to) spiser \\
\hline (mii) borrat & (vi) spiser \\
\hline (dii) borrabehtet & (dere) spiser \\
\hline (sii) borret & (de) spiser \\
\hline
\end{tabular}




\section{Stadieveksling}

Et fenomen i samisk språk er den såkalte stadievekslingen, som innebærer at konsonanter i ordets kjerne veksler ved bøyning i lengde, f.eks. borat - borrá (se eksemplene ovenfor) eller kvalitet, f.eks. loddi 'fugl' - lotti 'fuglens'. Det finnes et stort antall slike konsonantvekslinger som har betydningsbærende egenskaper ved verb- og nomenbøyning. Et faktum som støtter hypotesen om at sørsamisk er blitt atskilt fra de øvrige samiske språkene meget tidlig i historien, er at sørsamisk er den eneste samiske varieteten som mangler stadieveksling.

\section{Kasus}

Samisk benytter i stor utstrekning kasusformer av nomen, dvs. substantiv, adjektiv, pronomen og tallord, i stedet for preposisjoner, f.eks. (saN) váris ('på fjellet'), som er en kasusform (lokativ) av várri ('berg, fjell'). Det finnes sju kasusformer i samisk. I nordsamisk er formene for genitiv og akkusativ forent, på samme måte som formene for elativ og inessiv (og kalles vanligvis lokativ).

\begin{tabular}{lll}
\hline nominativ & sápmi & same \\
\hline genitiv & sámi & samens \\
\hline akkusativ & sámi & en same \\
\hline illativ & sápmái & til en same \\
\hline elativ & sámis & fra en same \\
\hline inessiv & sámis & hos en same \\
\hline komitativ & sámiin & med en same \\
\hline essiv & sápmin & slik som en same \\
\hline
\end{tabular}

I samisk finnes verken ubestemt eller bestemt artikkel, og f.eks. sápmi kan bety 'same', 'samen' eller 'en same' avhengig av kontekst.

I og for seg er det (noen) preposisjoner i samisk, f.eks. birra dálu (rundt huset), men det er mer vanlig med postposisjoner, som altså står etter hovedordet, f.eks. dálu duohken (bak huset; egentlig 'husets bakenfor’). 
Kasussystemet innebærer også at ordstillingen ikke er like viktig som f.eks. på norsk for at betydningen skal være klar. I setningen Niila oaidná Máhte (Nils ser Mattias) er det Nils som ser Mattias selv om ordstillingen hadde vært en annen, f.eks. Máhte oaidná Niila. Ordet Máhte står i kasus akkusativ og er objekt i setningen, mens Niila står i nominativ og er subjekt i setningen. Det vanlige er imidlertid at subjektet kommer før objektet. Ordstillingen er derfor ikke uten betydning, men kan ha stilistiske funksjoner eller angi fokus. Man kan imidlertid ikke si at samisk har fri ordstilling, siden det er begrensninger for den.

\section{Avledning av ord}

Formrikdommen består også av muligheten for å danne nye ord ved hjelp av endelser, såkalte avledningsendelser. Av verbet borrat (spise) kan f.eks. følgende nye verb dannes med avledningsendelser:

\begin{tabular}{ll}
\hline borralit & spise raskt \\
\hline borastit & spise lite \\
\hline boradit & spise (et måltid) \\
\hline borahit & mate (noen) \\
\hline borahallat & bli bitt \\
\hline borrojuvvot & spises \\
\hline
\end{tabular}

I tillegg til å danne verb av verb kan man f.eks. danne substantiver av verb, av f.eks. borrat kan man danne borramuš ('det å spise', dvs. mat). Det finnes mange muligheter til å danne nye ord ved hjelp av avledningsendelser, men alle endelser er ikke like produktive, dvs. at det finnes begrensninger for hvilke avledninger som er mulige. Nye ord dannes fortløpende bl.a. ved hjelp av avledningsendelser, f.eks. dieđáhus (informasjon) av dieđihit (meddele), bagadeaddji (veileder/rådgiver) av bagadit (gi råd/gi anvisning), čoavddus (løsning (av problem)) av čoavdit (løse), čálán (skriver, eng. printer) av čállit (skrive). (Se nedenfor for spesielle tegn i samisk.) 
Det er et spesielt verb - negeringsverb - som benyttes i benektende setninger, f.eks. mon in dieđe (jeg vet ikke). Negeringsverbet bøyes i ulike personer, mens hovedverbet dieđe av diehtit (vite) har en infinitt verbform og er ubøyd. I preteritum benyttes en annen infinitt verbform.

\begin{tabular}{ll}
\hline mon in dieđe & jeg vet ikke \\
\hline mii eat dieđe & vi vet ikke \\
\hline mon in diehtán & jeg visste ikke \\
\hline mii eat diehtán & vi visste ikke \\
\hline
\end{tabular}

\section{Tempus og modus}

Utover presens og preteritum finnes - slik som f.eks. i de skandinaviske språkene - også tempusformer i perfektum og pluskvamperfektum (i modus indikativ) som dannes med hjelpeverbet leat. I samisk bøyes imidlertid hjelpeverbet etter person, numerus og tempus.

\begin{tabular}{ll}
\hline son lea oastán ođđa biila & han/hun har kjøpt en ny bil \\
\hline mon lean oastán ođđa biila & jeg har kjøpt en ny bil \\
\hline son leai oastán ođđa biilla & han/hun hadde kjøpt en ny bil \\
\hline mon ledjen oastán ođđa biilla & jeg hadde kjøpt en ny bil \\
\hline
\end{tabular}

Indikativ er en modus som angir at det som sies, skal oppfattes som sant. Andre modi i samisk er imperativ som angir at det som sies, skal oppfattes som en oppfordring eller befaling, f.eks. Boađe sisa! (Kom inn! - sies til én person). Hadde det dreid seg om to personer, ville verbet ha fått en annen form: Boahtti sisa! og hvis enda flere personer: Bohtet sisa!

Utover dette finnes verbformer i kondisjonalis, som (bl.a.) angir forutsetninger, f.eks. Mon vuolggášin dohko, jus ... (Jeg skulle reist dit hvis ...), og potensialis, som angir tvil, f.eks. In dieđe bođeš go son ihttin (Jeg vet ikke om han kommer i morgen). Dette innebærer at man av ett samisk verb, f.eks. borrat (spise), kan danne 45 ulike bøyningsformer. 


\section{Skrivemåte og språklyd}

Det nordsamiske alfabetet har følgende tegn:

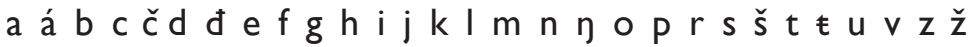

Vokalen á er en lang vokal og kan skille mellom f.eks. uttalen av manná 'han går' og mánná 'barn'. Vokalen o uttales som en norsk å-lyd og u uttales som en norsk o-lyd, f.eks.:

\begin{tabular}{lll}
\hline loddi & [låd.di] & fugl \\
\hline unni & [on.ni] & liten \\
\hline Punktum angir grense for en stavelse. & \\
\hline
\end{tabular}

Tegnet $c$ betegner en tse-lyd og $\check{c}$ en tje-lyd og $z$ og $z$ tilsvarer stemte lyder, f.eks.:

\begin{tabular}{lll}
\hline čáhci & {$[$ tjah.tsi] } & vann \\
\hline vázzit & [vad.dsit] & gå \\
\hline oažžut & [oad.dtjot] & få \\
\hline
\end{tabular}

Tegnet $\check{s}$ tilsvarer en sje-lyd, f.eks.:

\begin{tabular}{lll}
\hline šaddu & [sjad.do] & växt \\
\hline
\end{tabular}

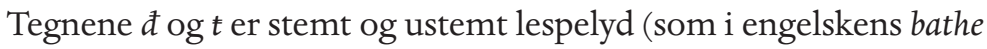
resp. bath).

\begin{tabular}{lll}
\hline lieđđi & [liedh.dhi] & blomst \\
\hline muokzá & [muoth.tha] & tante (på morssiden) \\
\hline
\end{tabular}




\section{Skriftspråk}

Den første samiske boken ble trykt i 1619. Det var en svensk prest i Piteå, Nils Andersson, som hadde oversatt en ABC-bok og en liten messebok til dårlig sørsamisk. De fleste bøkene som ble gitt ut på samisk før 1900-tallet, var som regel oversettelser av Bibelen eller andre kirkebøker.

I løpet av 1700-tallet ble det utviklet et bokspråk, det såkalte sørlappiske bokspråket, som bygde på nordlig sørsamisk og var tenkt som felles skriftspråk for alle samer. Innenfor kirken og skolen hadde det sørlappiske bokspråket en sterk stilling også på 1800-tallet, og undervisningsbøker ble fortsatt gitt ut på sørlappisk i siste halvpart av 1800-tallet. Mot 1800-tallets slutt opphørte imidlertid utgivelsene på dette bokspråket.

Den første nordsamiske boken, en katekisme, ble trykt i 1728 i Norge. Ortografien var utviklet av presten Knuud Leem, som også utga både en grammatikk og ordbøker. Senere på 1800-tallet utviklet den norske presten Nils V. Stockfleth en ny nordsamisk ortografi med spesielle samiske tegn. En stor nordsamisk ordbok ble utarbeidet av J.A. Friis (som ble professor i samisk og finsk ved Universitetet i Oslo i 1866), og denne ordboken ble utgitt i 1887.

Et nordsamisk standardspråk - som bygger på de finnmarkssamiske varietetene - ble kodifisert av Konrad Nielsen, og hans store ordbok ble publisert 1926-29. På basis av Nielsens skrivemåte ble det $\mathrm{i}$ 1948 av Knut Bergsland og Israel Ruong utviklet en nordsamisk ortografi (som bygger på den dialekten som snakkes i Guovdageaidnu) som var felles for Norge og Sverige. I Finland ble det på samme tid benyttet en annen ortografi for nordsamisk, som var utarbeidet av Paavo Ravila i 1930-årene og senere modifisert av Erkki Itkonen i 1950-årene.

I 1970-årene utviklet Samiska språknämnden en felles ortografi for nordsamisk i Norge, Sverige og Finland, som er blitt godkjent av Nordisk samekonferanse, og som siden 1979 har vært brukt $i$ alle de tre landene. I nordsamisk ortografi, til forskjell fra sørsamisk og lulesamisk, benyttes spesielle tegn ( $(\check{c}, \mathrm{~d}, \mathrm{y}, \breve{s}, \mathrm{t}, \mathrm{z}$ ).

Det finnes nå seks ulike ortografier for samiske språk: i tillegg til nordsamisk også sørsamisk (godkjent i 1978), lulesamisk (1983), enaresamisk, skoltsamisk og kildinsamisk. Kildinsamisk tar utgangspunkt i det kyrilliske alfabetet. 


\section{Språkets situasjon i samfunnet}

Samisk brukes først og fremst innenfor familien, blant de nærmeste vennene og i tradisjonelle samiske næringer som f.eks. reindrift. I løpet av de siste tiårene har imidlertid bruken økt på andre arenaer, f.eks. innenfor medier, administrasjon og undervisning. Dette henger sammen med en økt bevissthet om samisk kultur og samisk språk som den «samiske kulturrevolusjonen» i 1970-årene ga opphav til. I 1970-årene kunne samisk joik og musikk bli hørt offentlig for første gang, og poeter leste dikt på samisk. Man begynte å bruke samisk i bøker og høre språket i mange nye sammenhenger.

Språkbruken innenfor familien er den helt avgjørende faktoren for språkets bevaring. Hvis foreldrene snakker samisk med sine barn, vil barna lære seg samisk. Men det er også viktig at samisk brukes på andre arenaer. Fremfor alt gjelder dette i skolen og annen undervisning. Det er viktig at det blir undervist på samisk på skolen i tilstrekkelig utstrekning til at språket kan utvikles naturlig. Et annet område er medier som tv og aviser. En god språkutvikling forutsetter også at det finnes et godt tilbud innenfor litteratur. Disse forholdene varierer for dem som snakker de ulike samiske språkene i de ulike landene.

\section{Lovgivning}

Lovgivningen gir ikke samme beskyttelse for de ulike samiske språkene. Nordsamisk er nå lovbeskyttet både i Norge, Sverige og Finland, innenfor enkelte geografiske områder. Det gir bl.a. en rett for dem som snakker samisk, til å bruke samisk i kontakt med enkelte myndigheter med ansvar for saker som gjelder samene. I Norge dekker lovgivningen enkelte kommuner i det området der nordsamisk snakkes, og i Finland dekker lovgivningen et område som i tillegg til nordsamisk også omfatter enare- og skoltsamisk. I Sverige gjelder lovgivningen det lule- og nordsamiske området.

Lovgivningen dekker altså ikke det lulesamiske området i Norge og overhodet ikke sørsamisk, verken i Norge eller i Sverige. I Russland finnes ingen språklovgivning som omfatter de samiske språkene. 
Språklovgivningen har fremfor alt i Norge gitt opphav til et omfattende språkarbeid når det gjelder f.eks. oversettelse av dokumenter. I Sverige har språklovgivningen hittil ikke hatt noen større betydning for anvendelsen av samisk hos de myndigheter som lovgivningen omfatter. Dette skyldes for en stor del at mange samer er uvant med å bruke tolk. I stedet for å benytte sitt beste språk snakker de svensk, som de behersker mye dårligere. Ved universitetet i Umeå pågår akkurat nå en utdannelse av nordsamiske tolker, noe som burde føre til at bruken av tolk blir mer vanlig når samisktalende personer har kontakt med myndighetene.

\section{Samisk i undervisningen}

Det er også betydelige forskjeller når det gjelder tilbudet innenfor undervisning og utdannelse i de samiske språkene. Det har vært undervist i nordsamisk på grunnskolenivå i Sverige, Norge og Finland i ganske mange tiår, og også på videregående skoler, fremfor alt i Norge. I Sverige finnes spesielle sameskoler for 1. til 6. klassetrinn. Sameskolene har i sin undervisning et innhold som er tilpasset samiske forhold. I noen av disse brukes samisk som undervisningsspråk. I skolene i Guovdageaidnu og Kárášjohka (i Norge) og i Ohcejohka (i Finland) benyttes også samisk som undervisningsspråk. Muligheten til å få undervisning i lulesamisk og fremfor alt i sørsamisk har vært begrenset, og dreier seg om noen få timers undervisning per uke.

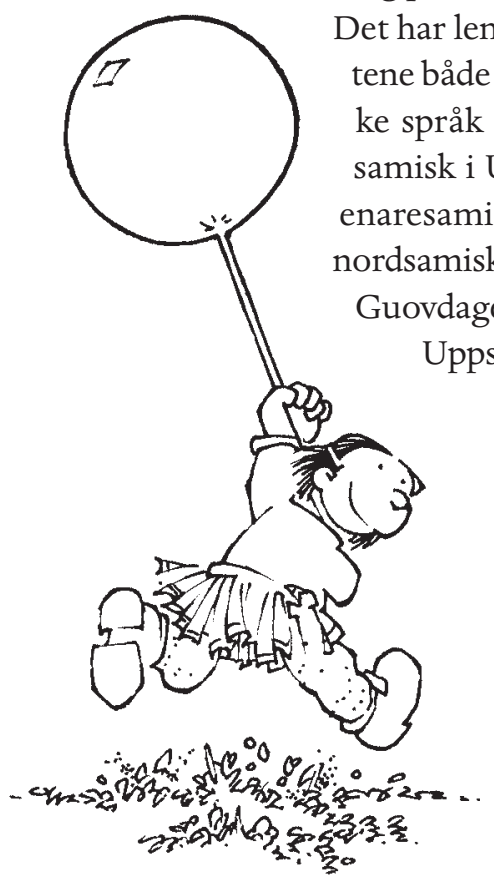




\section{Samisk i mediene}

Tilbudet i mediene varierer. Det finnes to nordsamiske aviser som blir utgitt på norsk side, Min Áigi (Vår Tid) og Áššu (Gloild). Førstnevnte avis ble gitt ut på prøve i et lulesamisk opplag én gang ukentlig i noen måneder, men den utgivelsen har nå opphørt.

Daglige radioprogrammer, i hovedsak på nordsamisk, forekommer både i Norge, Finland og Sverige. Både på norsk og svensk side er det jevnlig programmer på lule- og sørsamisk samt på enare- og skoltsamisk på finsk side. På russisk side har man nylig startet sendinger på kildinsamisk gjennom et samarbeid mellom de nordiske landenes sameradioredaksjoner. Russiske samer har gjennom samarbeidet fătt utdannelse for oppgaven.

Som en samproduksjon mellom Norge, Sverige og Finland sender tv 15 minutter lange nyhetsprogrammer på nordsamisk mandag til fredag. De samiske tv-redaksjonene produserer også samiske barneprogrammer, som vises jevnlig.

\section{Litteratur og musikk}

Selv om den første boken på samisk ble publisert i 1619, varte det helt til begynnelsen av 1900-tallet før samiske forfattere selv begynte å skrive på samisk. I Norge skrev Anders Larsen romanen Beaivvi álgu (Morgengry), som ble gitt ut i 1912. På finsk side kom Pedar Jalvis dikt- og novellesamling Muohtačalmmit (Snøfnugg) ut i 1915. Enda viktigere var imidlertid utgivelsen av Johan Turis bok Muitalus sámiid birra (Fortellingen om samene), som ble gitt ut i første opplag i 1910. Alle disse er trykt i nye opplag og brukes f.eks. i undervisningen på universitetene.

Fra 1970 og fremover har flere samiske forfattere gitt ut bøker og diktsamlinger både i Norge, Sverige og Finland, bl.a. Paulus Utsi, Nils Aslak Valkeapää, Kirsti Paltto og Elle Marja Vars. Av disse har Nils Aslak Valkeapää (som på samisk het Áillohaš) vært den mest betydningsfulle, både som forfatter, kunstner og joiker. Han fikk Nordisk Råds litteraturpris i 1991 for diktsamlingen Beaivi áhčážan (Solen, min far) fra 1988. 
I et dikt beskriver Paulus Utsi sitt liv med bilder fra naturen.

$\begin{array}{ll}\text { Reagganan ráhkisvuohta } & \text { Kjærlighet som smerter } \\ \text { Nu go roạkesoahki } & \text { Likesom en krokete bjerk } \\ \text { orru duottarravddas } & \text { ved fjellets rand } \\ \text { nu lea biegga botnjan } & \text { er mitt liv } \\ \text { mu nai eallima } & \text { tuktet av vinden } \\ \text { Nu go soagi mátta } & \text { Likesom bjerkens stamme } \\ \text { bievlla vuostá čuovgá } & \text { skinner mot snøfri jord } \\ \text { nu ohcalan váriide } & \text { lengter jeg til fjellet } \\ \text { láguide ja oruhagaide } & \text { viddene og boplassene } \\ \text { Dat lea mu eallin } & \text { Det er mitt liv } \\ \text { man mon ráhkistan } & \text { som jeg elsker }\end{array}$

Joik og annen samisk musikk fikk et virkelig oppsving i 1970-årene og i spissen for denne utviklingen sto allerede den nevnte Nils Aslak Valkeapää. Han ga ut en plate med joiker, der tradisjonell joik er kombinert med instrument. Hans plate fikk en slik gjennomslagskraft blant samene at det førte til at unge samer begynte å fremføre joiker og sanger på samisk på scenen. Deretter fortsatte han å utvikle den samiske musikken og ga ut flere cd-er med samisk joik i kombinasjon med instrument. Det finnes i dag en rekke samiske musikere, og de mest kjente er Marie Boine (som fikk Nordisk Råds musikkpris i 2003) og Wimme Saari, som begge har gitt ut flere cd-er.

Det har i flere år vært arrangert en årlig musikkonkurranse i Guovdageaidnu i forbindelse med påsken. Der konkurrerer artister $\mathrm{i}$ to klasser for joik og samisk musikk. Interessen for konkurransen har økt etter hvert, og nå deltar artister fra nesten hele Sápmi. Musikken har dermed fătt betydning for bruken av samisk i samfunnet.

\section{Samfunnet ellers}

Nordsamisk har i det hele tatt en sterk posisjon i samfunnet sammenlignet med øvrige samiske språk og dialekter. I Guovdageaidnu og Kárášjohka på norsk side samt Ohcejohka på finsk side (alle innenfor det nordsamiske området) utgjør samene et flertall i kom- 
munene. Bruken av samisk har bl.a. takket være språklovgivningen økt i samfunnet i løpet av det siste tiåret, bl.a. innenfor administrasjonen. På kart over fjellområdene angis nå stedsnavnene på samisk utfra den dialekt som snakkes i området, og veiskiltene har også fått samiske navn, f.eks. Giron (Kiruna).

En viktig faktor har også vært opprettelsen av særskilte sameting i Norge, Sverige og Finland. Sametingenes medlemmer velges ved valg av personer som er stemmeberettiget i de respektive land, og er derigjennom samenes folkevalgte parlament i vedkommende land. Sametingene har bl.a. oppnevnt et felles samisk språkråd, som blant annet sørger for planleggingen av de samiske språksakene i samfunnet. I språkrådet er det også representanter for de russiske samene.

Oversettelse fra svensk: Kari Styren

\section{Litteratur}

Hyltenstam, Kenneth, Christopher Stroud \& Mikael Svonni (1999): «Språkbyte, språkbevarande, revitalisering. Samiskans ställning i svenska Sápmi»». I: Kenneth Hyltenstam (red.): Sveriges sju inhemska språk - ett minoritetsspråksperspektiv. 41-97. Lund: Studentlitteratur.

Korhunen, Olavi (1997): «Hur samiskan blev samiska». I: Eva Westergren \& Hans Åhl (red.): Mer än ett språk.
En antologi om två- och trespråkigheten i norra Sverige. 79-115. Norstedts ordbok.

Magga, Ola Henrik (1997): «Samisk språk». I: Språkene i Norden. Utgitt av Nordisk språksekretariat. 137-160.

Oslo: Novus.

Sammallahti, Pekka (1998): An Introduction to Saami Languages. Kárášjohka: Davvi Girji.

\section{Internett}

Samiska studier, Umeå universitet:

Sámi Allaskuvla, Guovdageaidnu:

Giellagas, Oulu universitet:

Samiske studier, Universitetet i Tromsø:

Nordisk samisk institutt, Guovdageaidnu:

Sametinget i Sverige:

Sametinget i Norge:

Sametinget i Finland:
www.umu.se/samiska
www.samiskhs.no
www.giellagas.oulu.fi
www.sami.uit.no
www.nsi.no
www.sametinget.se
www.samediggi.no
www.samediggi.fi 



\section{CARL CHRISTIAN OLSEN}

\section{Kalaallisut - grønlandsk}

Det språket som er hovedspråket i Grønland, kalles kalaallit oqaasii eller kalaallisut. Det tales av omtrent 50000 mennesker hvorav en del er tospråklige med dansk som det andre språket. Historisk sett er kalaallisut beslektet med en rekke andre eskimoiske språk, og man taler her om den eskaleutiske språkstamme idet eskimoisk og aleutisk er de viktigste ingrediensene (se figur 1).

\section{Forholdet mellom tale- og skriftspråk}

Som i alle språksamfunn skjelner man mellom talt kalaallisut med en rekke hoveddialekter, som dog alle er innbyrdes forståelige, og skriftspråket kalaallisut. Det grønlandske skriftspråket, som anvendes av alle grønlendere, har de samme funksjoner som andre standardspråk og anvendes innenfor utdannelsessystemet, til fag- og skjønnlitteratur og i de trykte mediene samt til teksting i tv.

Opprinnelig tok man i utviklingen av skriftspråket utgangspunkt i det midtvestgrønlandske dialektområdet, hvor hovedstaden Nuuk, dengang Godthåb, ligger, og hvor den vesentligste utdannelsesinstitusjonen i det gamle Grønland, seminariet Ilinniarfissuaq/ Grønlands Seminarium, lå og stadig ligger. Derfra ble grunnen også lagt til den grønlandske litterære tradisjon omkring 1860.

Det nåværende skriftspråket er i prinsippet forståelig for alle grønlandsktalende, idet det er utviklet på bakgrunn av bidrag fra dialektområdene fra nord og syd, samt fra Avanersuaq (Thule) og Tunu (Øst-Grønland: med de to viktige dialektområdene Ammassalik-området og Illoqqortoormiut (Scoresbysund)-området. Se figur 1). Vi vender tilbake til utviklingen av skriftspråket i siste avsnitt.

Selv om det ikke umiddelbart er gjensidig forståelighet mellom de ytterstliggende dialektområdene, er språkets struktur den samme innenfor hele området. Langt de fleste forstår derfor hverandre etter en kortere tilvenningsperiode. 

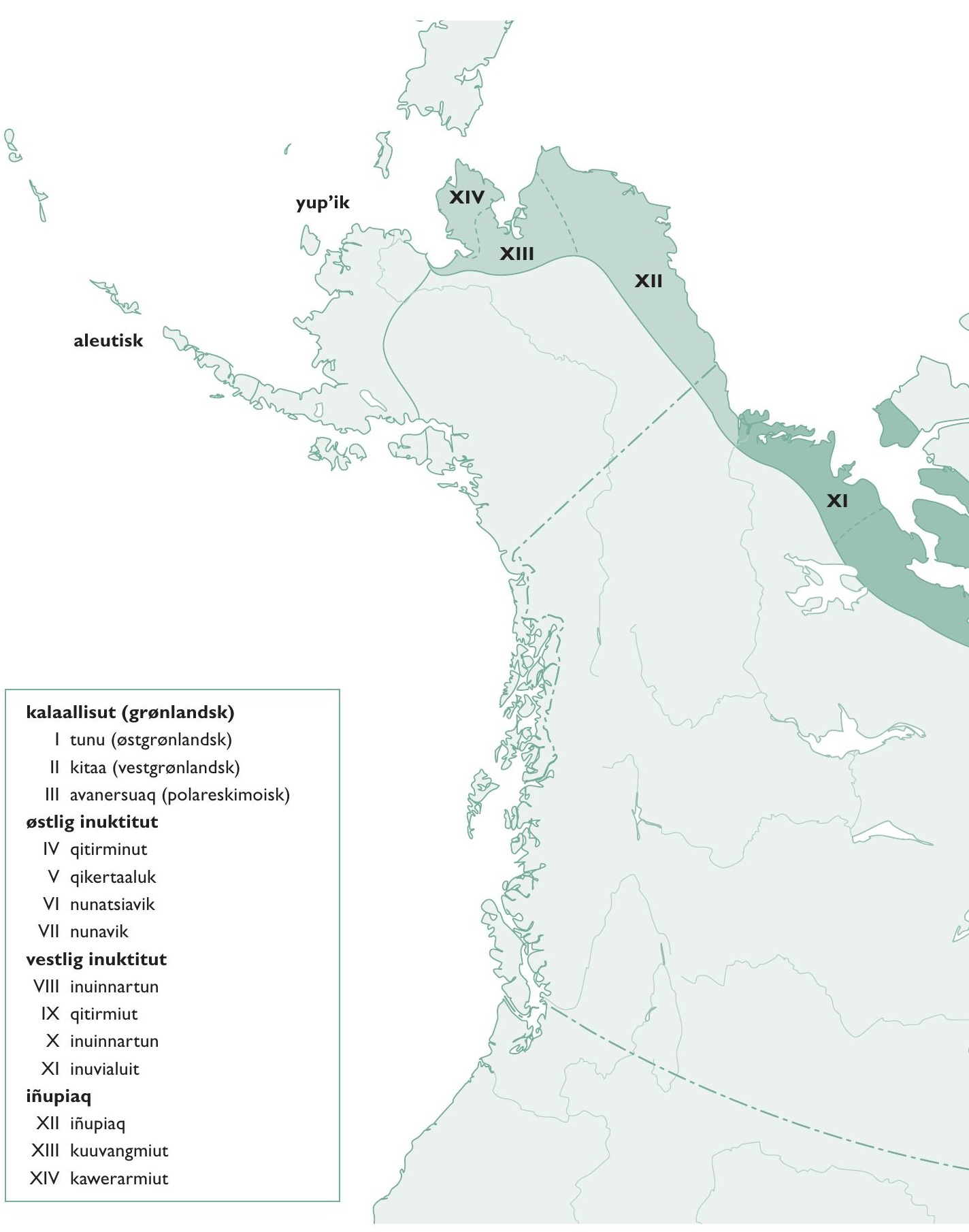

Figur 1: Alt i alt tales inuittspråkene av ca. 150000 mennesker, av disse er også medregnet emigranter til USA, det sørligere Canada, Danmark og storbyområdene i Russland 

(2)

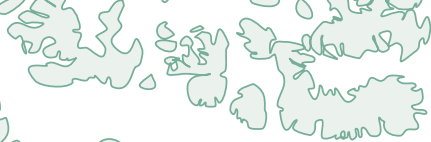
nो
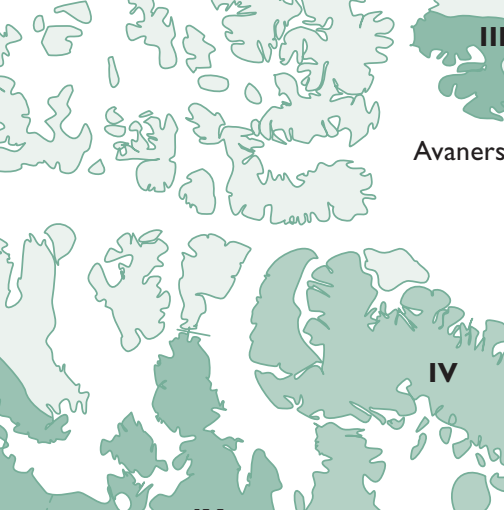

III

Avanersuaq

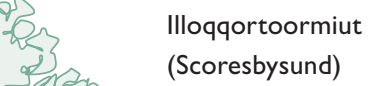

है

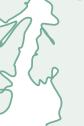

Avanersuag

तर
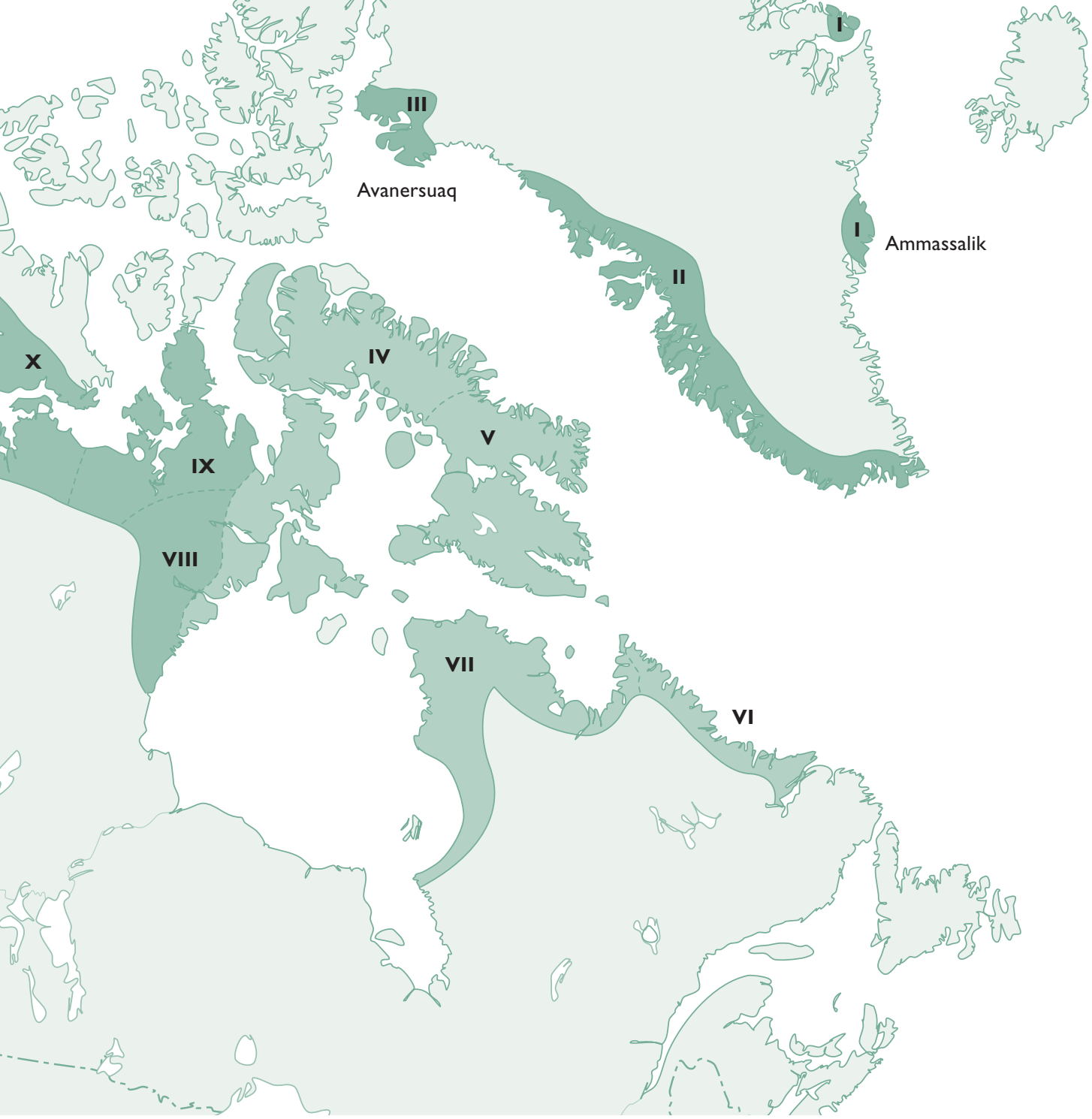


\section{Grønlandske dialekter}

Det er tre hoveddialekter av grønlandsk: avanersuaq (nordligste Grønland), tunu (Øst-Grønland) og kitaa (Vest-Grønland).

Innenfor disse hovedområder er det atskillige underdialekter, spesielt når det gjelder vestgrønlandsk. Fra Upernavik i nord til Kapp Farvel i syd er det språklige variasjoner med hensyn til uttale, ordvalg og tonegang (= 'melodien i språket'), og på visse områder kan også morfologiske og grammatiske forskjeller gjøre seg gjeldende, dvs. at det er varierende regler for ord- og setningsdannelse.

\section{Hva heter det på grønlandsk?}

Når man snakker om Grønland, er det viktig å være oppmerksom på at Grønland er et navn gitt av utenfrakommende, nemlig de tidligste nordboerne, dvs. de utvandrede personene fra Norge som 'oppdaget' Grønland $\mathrm{i}$ år 982. På kalaallisut heter landet Kalaallit Nunaat.

Grønlendere bruker selv andre betegnelser på landets innbyggere, som også vil bli brukt her:

\section{Inuk/inuitt}

Inuk, i flertall inuitt: er den betegnelsen som grønlendere og andre inuitt-grupper bruker om seg selv. Ordet inuk betyr 'menneske'. Av folk utenifra ble grønlenderne tidligere kalt eskimoer.

\section{Eskimo}

Ordet eskimo menes å stamme fra det indianske språket som tales $\mathrm{i}$ den nåværende kanadiske provinsen Québec. De første som brukte ordet var jesuittmisjonærer i begyn- nelsen av 1600-tallet. Den ene fortolkningen av ordet er at det skulle bety 'de som spiser rått kjøtt', og det er den som er den mest sannsynlige. En mer kuriøs fortolkning fører ordet tilbake til 'ekskommunikert' (dvs. bortvist fra den katolske kirke).

\section{Kalaaleq}

Kalaaleq, i flertall: kalaallit. Man vet ikke hvor ordet stammer fra, men det brukes nå om beboere i Grønland. Kanskje stammer betegnelsen fra at de første som kom til Grønland, trodde at det var en fast landforbindelse mellom Grønland og den finske regionen Karelen, der det kom mange hvalfangere fra. Poul Egede, sønn av den norske presten som var misjonær i Grønland, Hans Egede, nevner i sin ordbok at grønlenderne kaller seg selv inuitt, men presenterer seg som karalit (kareler/ kalaallit) overfor fremmede. 
Det har lenge vært forsket i Grønlands forhistorie, og språkfolk og arkeologer er nå av den oppfatning at innvandringen til Grønland har skjedd i fire omganger. De folk som innvandret, var i alle fire tilfeller eskimoer, men det viser noe om de ugjestmilde forholdene i tidligere tider at det har vært fire forskjellige innvandringsbølger. Disse bølgene kan til en viss grad ses avspeilet i dialektene.

\section{Karakteristika ved kalaallisut}

\section{Et agglutinerende språk}

Det grønlandske språket, kalaallisut, atskiller seg markant fra de språkene som snakkes i Vest-Europa, og som gymnasiaster i de nordiske landene kjenner som fremmedspråk, f.eks. tysk, engelsk, spansk og fransk. I motsetning til disse språkene, som har korte ord med kun en enkelt eller få stammer (f.eks. 'vinglass', som er satt sammen av stammene 'vin'+'glass'), har man på kalaallisut ofte mange stammer innenfor et enkelt ord. Det betyr at ordene er lange og komplekse.

Denne typen av språk, hvor stammene 'limes sammen', kalles agglutinerende språk, (jf. engelsk glue), og de er meget alminnelige ut over verden, men altså ikke i Vest-Europa.

\section{Sammensatte og komplekse ord}

Som eksempel på et sammensatt ord som svarer til en hel setning på nordiske språk, kan nevnes: Silagissiartuaarusaarnialerunarpoq. Det skal oppløses i: sila-gi-ssi-artu-aa-rusaar-nia-ler-unar-poq: 'vær-godt-blir-går hen-langsomt-grad-

vist-akter-begynne-visstnok-1. p. entall' (det ser visstnok ut til gradvist å bli bedre vær). Merk at været er 1. p. entall på kalaallisut.

Se også avsnittet om morfologiske forhold nedenfor.

\section{Et ergativt språk}

Et ytterligere karakteristisk trekk for kalaallisut er at det er et ergativt språk. Et trekk som vedrører kasusforhold i henholdsvis transitive setninger (setninger med både subjekt og objekt) og intransitive setninger (setninger uten objekt). Ergativitet kjennes i VestEuropa bare fra grønlandsk og baskisk. 
I nominativ-akkusativ-språk, som latin, tysk og dansk, står subjektet både i transitive og intransitive setninger i nominativ. I motsetning til dette gjelder det for ergative språk at subjektet i en transitiv setning står i en annen kasus enn subjektet i en intransitiv. Ergative språk klassifiserer subjektet $i$ en intransitiv setning som 'det samme' i syntaktisk henseende som objektet i en transitiv. Det betyr at subjekt og objekt i de to forskjellige setningstypene har samme kasus (nemlig absolutiv), mens subjektet i en setning med objekt (en transitiv setning) har en annen kasus, som man tidligere kalte ergativ. Den kalles nå relativ.

\section{Transitive og intransitive setninger}

I setningen 'Peter spiser kjøttet' har I setningen 'Peter spiser' (en intransitiv ordet 'Peter' (Piitaq, et lånord) formen Piitap med endelsen - $p$, fordi det er setning) opptrer Piitaq i absolutiv, og subjekt i en transitiv setning: Piitap neqi setningen lyder: Piitaq nerivoq. Verbet nerivaa, og verbalendelsen -vaa viser viser med endelsen -voq at det her at det er objekt (nemlig kjøttet). Neqi er en intransitiv setning.

er for øvrig den samme stammen som neri-, det å spise var opprinnelig å fortære kjøtt.

\section{Morfologiske forhold}

Ordstrukturen i kalaallisut kan oppsummeres ved hjelp av begrepene: stamme, suffiks og endelse.

Som i andre språk viser en ordstamme til 'noe i verden', en ting eller en aktivitet, men på kalaallisut er stammene ikke på forhånd definert som enten substantiver eller verb. Ordet neri (spise), som inngår $i$ eksemplet nedenfor, er en slik stamme. 
Også endelser svarer til det vi kjenner fra vesteuropeiske språk, især de språk som har personendelser. På tysk uttrykker -st 2. person entall. På kalaallisut uttrykker -punga 1. person entall. Merk at man på kalaallisut skjelner mellom verb som har objekt (er transitive), og verb som ikke har det (er intransitive). De har forskjellige personendelser, jf. avsnittet om ergativitet.

Endelig er det de størrelsene som vi for letthets skyld kaller suffikser, og som på kalaallisut tjener til å presisere en lang rekke forhold som vi på nordiske språk gjerne bruker hjelpeverb (kunne, burde, skulle, ville, ha, måtte) eller adjektiver til.

\section{Grønlandske ords struktur}

Vi kan nå beskrive strukturen i det grønlandske ordet på følgende måte:

\{Stamme- $\quad \mathrm{X}$-antall suffikser- endelser\}

Inndelt i disse tre leddtypene kan et grønlandsk ord f.eks. se ut som følger:

Neri-

artor-nia-ler-

punga

Oversatt ledd for ledd:

(spise-)

(bevege sig hen-akter-

(1. person entall,

begynner-)

uten objekt)

Ordrett oversettelse:

'jeg akter å begynne å gå hen for å spise'

Betydning:

'jeg vil gå hen og spise'

Man kan innenfor rammene av ett ord variere utsagnet eller uttrykket nesten uendelig etter behov. Suffikser kan gradbøye, nyansere, tidsbestemme, bekrefte/avkrefte osv.

Vi har ovenfor sett et eksempel med et ord som på norsk svarer til en hel setning. Det hadde en stamme som utgangspunkt, flere suffikser og en personendelse. Men endelser kan også knytte seg til stammer og f.eks. angi kasus. Da blir stammen oppfattet som et substantiv. 


\section{Kasusforhold}

Kalaallisut har som nevnt $i$ avsnittet om ergativitet de to hovedkasus absolutiv og relativ.

\section{Absolutiv}

Piitaq nerivoq: 'Peter spiser'

(Piitaq står i dette tilfelle i absolutiv kasus, da det ikke er objekt i setningen)

\section{Relativ}

Piitap neqi nerivaa: 'han spiser det', 'Peter spiser kjøttet'

(Piitaq står her i relativ og er dermed endret til Piitap fordi det er objekt

i setningen, hvilket også kommer til uttrykk i endelsen i verbet nerivaa)

Men det er også seks andre kasus som ofte angir forhold som uttrykkes med preposisjoner på de nordiske språkene:

\section{- Stedsbestemmende}

-mi (svarer til tysk dativ, russisk lokativ)

Piitaq Nuummi (Nuuk + mi) inuuvoq:

'Peter er født i Nuuk'

\section{- Målbestemmende}

-mut (svarer til akkusativ på tysk og latin)

Umiarsuaq Qaanaamut (Qaanaaq + -mut) tikippoq:

'Skipet/et skip er ankommet til Qaanaaq'

\section{- Utgangspunktsbestemmende}

-mit

Timmisartoq Københavnimit (København + -mit) aallarpoq:

'Flyet avgikk fra København'

\section{- Instrumentbestemmende}

-mik (svarer til russisk instrumentalis)

Allunaasaq savimmik (savik 'kniv' + -mik) kipivaa:

'Han/hun skjærer tauet med en kniv' 


\section{- Likhetsbestemmende}

-tut

Qulleq seqinertut (seqineq 'sol' + -tut) qaamatiginngilaq:

'Lampen er ikke så lys som solen'

\section{- Gjennomgangsbestemmende}

-kkut

Aqqusinikkut (aqqusineq 'vei' + -kkut) pisuppunga:

'jeg går på veien'

Legg merke til at verken kjønn eller bestemthet uttrykkes grammatisk på kalaallisut (derfor står det i oversettelsen 'han/hun' og 'skipet/et skip').

\section{Personendelser}

Grønlandsk har tre personendelser samt tredje person refleksiv.

Anaanani napparsimammat atuanngilaq:

'Han går ikke på skolen fordi hans (egen) mor er syk'

(anaana 'mor' + -ni 'sin egen' napparsima 'syk' -mmat 'kausativ + 3. p. entall' atua 'gå på skolen' + -nngi 'ikke' -laq '3. p. entall')

Napparsimagami atuanngilaq:

'Han går ikke på skolen fordi han selv er syk'

(naapparsima 'syk' + -ga 'kausativ' + -mi '3. p. refleksiv (han selv)'

atua 'gå på skolen' + -nngi 'ikke' -laq '3. p. entall')

Piitaq napparsimagami ilaangilaq:

'Peter er ikke med fordi han (selv) er syk'

(Piitaq 'Peter' napparsima 'syk' + -ga 'kausativ' + -mi '3. p. refleksiv (han selv)'

ilaa 'er med' + -nng 'ikke' + -laq '3. p. entall')

Piitaq napparsimammat pulaarparput:

'Vi besøker Peter, fordi han er syk'

(Piitaq 'Peter' napparsima 'syk' + -mmat 'kausativ 3. p. entall (fordi han)'

pulaar 'besøke' + -parput 'transitiv 3. p. flertall subjekt., 3. p. entall objekt') 


\section{Enklitiske endelser}

Felles for alle inuittspråk er en rekke spesielle endelser, som alle blir føyd til etter man har avsluttet utsagnet med de nødvendige elementer. Disse såkalte enklitiske endelser er: -mi (bekreftende/forsterkende) -gooq (etter sigende), -li (imidlertid), -lu (og), -luunniit (eller), -lusooq (som om), -taaq (også), -toq (ønske).

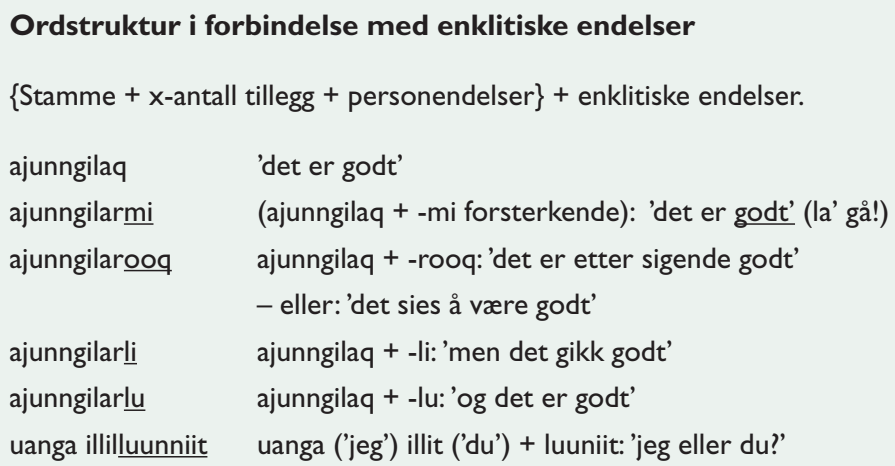

\section{Hovedverb og hjelpeverb}

Verb på kalaallisut finnes i to former, hovedverb og hjelpeverb. Dette svarer likevel ikke til verbalformer i de nordiske språkene, idet en del av de grønlandske hjelpeverbene uttrykker det man her uttrykker ved hjelp av underordnede setninger.

\begin{tabular}{lll}
\hline $\begin{array}{l}\text { Eksempler på hovedverb } \\
\text { fremsettemåte }\end{array}$ & pisuppunga & jeg går \\
$\begin{array}{l}\text { spørremåte } \\
\text { bydemåte }\end{array}$ & pisuppa? & går han? \\
ønskemåte & pisugit! & gå! \\
\hline Eksempler på hjelpeverb & & la meg gå \\
begrunnende & pisummatlanga & \\
ledsagemåte & pisullunga & fordi han gikk \\
fremtidsbetegnende & pisukkuma & mens jeg går \\
transitiv & takugiga & når jeg går \\
\hline
\end{tabular}




\section{Utviklingen av kalaallisut som skriftspråk}

Som omtalt i innledningen har inuitt ikke tradisjonelt vært en skriftkultur; skriftspråket er kommet til utenfra.

Siden de første europeiske kontakter har det vært gjort forsøk på å fastlegge et grønlandsk skriftspråk. De første systematiske tiltak tillegges Hans Egede (1680-1758) og hans prestemedhjelper Albert Topp, som i 1728 forsøkte å oversette skapelsesberetningen. Hans Egedes sønn, Poul Egede (1708-1789), utga en ordbok på grønlandsk, dansk og latin. Poul Egede vokste opp i Grønland og kunne språket fra barnsben av. Den første virkelig systematiske rettskrivning ble imidlertid utformet i 1851 av herrnhuteren Samuel Kleinschmidt (1814-1886).

Samuel Kleinschmidt var en stor fonetiker og konstruerte en rettskrivning som bevarte stammenes og suffiksenes form tilnærmelsesvis ens i alle sammensetninger. Det betydde at den grønlandske rettskrivningen ble nesten like så morfematisk som den nåværende danske, dvs. lett å lese, men vanskelig å stave, fordi det ikke var noen direkte relasjon mellom lyd og skrift. Suffiksene uttales nemlig forskjellig alt etter omgivelsene.

Kleinschmidts rettskrivning ble brukt til omfattende språklig og opplysende virksomhet både innad mot inuitt og utad mot omverdenen. Den konsistente rettskrivningen betydde grunnleggingen av et egentlig skriftspråk. Bl.a. til bruk for oversettelsen av hele Bibelen var man nødt til å utvikle en grønlandsk terminologi på flere områder, f.eks. betegnelser for samfunnsforhold, naturtyper og moralbegreper, som ikke tidligere eksisterte i det grønlandske språket.

For flere inuitt-dialektområder utenfor Grønland er Bibelen det eneste som foreligger i skrift. Men det at Kleinschmidt fikk konstruert en fasttømret og prinsipiell rettskrivning, gjorde det mulig å skrive alle slags tekster på språket, og man la dermed grunnen til den litteraturrikdommen som skiller grønlandsk fra mange andre fangstkulturer. Man hadde mulighet for å dokumentere egen kultur i skrift, oversette deler av verdenslitteraturen samt å fortolke nåtidens Grønland i eget språk - og til en viss grad hadde man også mulighet for å benytte språket $\mathrm{i}$ administrativt henseende. 
Kleinschmidts rettskrivning ble brukt frem til 1973, hvor man innførte den nye fonemiske rettskrivningen som gjør det lettere å skrive, i og med at skriften tilnærmelsesvis avspeiler lyden. Prinsippene i denne nye rettskrivningen gjør det mulig å skrive alle grønlandske dialektformer, om enn med særlige uttaleregler i ganske få tilfeller. Med innføringen av den nye rettskrivning har man likevel ikke helt avskaffet den gamle. Myndighetene er imidlertid blitt pålagt å bruke den nye rettskrivningen.

\section{Standardgrønlandsk}

Med opprettelsen av Ilinniarfissuaq / Grønlands Seminarium i Nuuk og Ilulissat i 1845 ble det gradvis oppbygd et grønlandsk standardspråk, først i form av en felles rettskrivning, men etter hvert gjennomgikk også talespråket en viss standardisering, slik at man nå med rimelighet kan tale om standardgrønlandsk. Standardgrønlandsk bygger på de vestgrønlandske dialektene som ble brukt ved seminariets undervisning. Senere er dette talespråket blitt institusjonalisert med ordbøker og grammatikker. Det er også en språknemnd for Grønland.

I løpet av standardiseringsprosessen er bl.a. særlige nordgrønlandske uttrykk vedrørende vinterfangst på isen og sydgrønlandske uttrykk for dyreavl og jordbruk blitt tatt opp i det felles ordforrådet (leksikon). Det har styrket det grønlandske språket. Det er satt punktum for diskusjonen om hvilken rettskrivning man skal bruke som den offisielle, men samti-

dig anerkjennes dialektale variasjoner i talespråket. Et rugbrød heter f.eks. offisielt iffiaq, men variasjoner omfatter: ikkiaq,

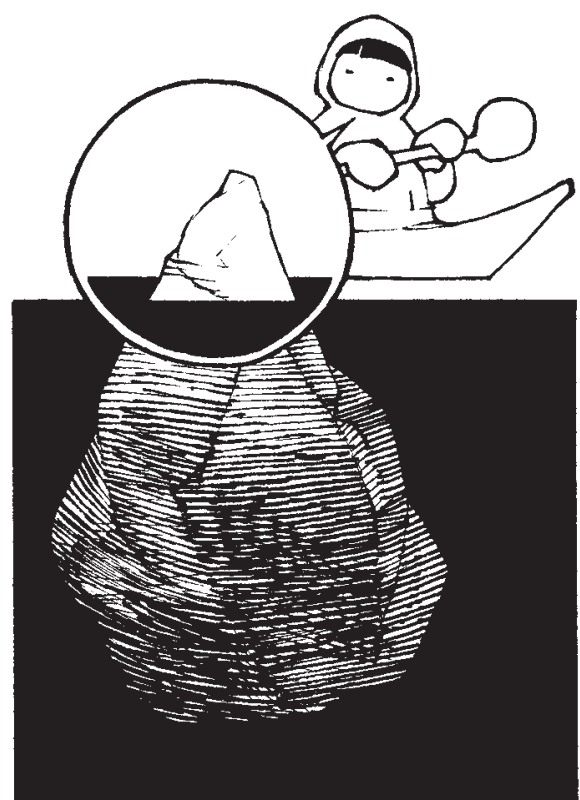
ippiaq, tiggaliaq, timiusiaq. Standardisering fordrer også at man bruker felles steds- og personnavn, men også her tillater man lokale variasjoner. 


\section{Lånord og fremmedord}

I den grønlandske språkpolitikken skjelner man som i andre språk mellom lånord og fremmedord.

De forskjellige kontaktene med diverse folk har gitt mange forskjellige fremmedord. F.eks. kan nevnes fem ord som menes å stamme fra nordboerne:

$\begin{array}{ll}\text { niisa } & \text { marsvin } \\ \text { sava } & \text { sau } \\ \text { kuanneq } & \text { kvann (plante) } \\ \text { kona } & \text { kvinne } \\ \text { musaq } & \text { gulrot (jf. norsk: mura) }\end{array}$

Folk som opprinnelig kom fra Island, Danmark-Norge, Frankrike, England-Skottland, Irland, Russland, men som slo seg ned i Grønland, har bidradd til kalaallisuts ordforråd på en rekke områder, f.eks.: tallord, tekniske termer, materialer, navigasjon på havet, landbruk, dyreavl samt betegnelser på kolonialvarer og andre bruksgjenstander.

Det er mange strukturelle likheter og forholdsvis stor gjensidig forståelighet mellom inuittspråk i dag, men de skiller seg bl.a. fra hverandre ved at tallordene fra 1 til 12 er farget av språksamfunnets dominerende europeiske kontakter. Man finner russiske tallord hos inuitt i Chukotka, amerikanske/ engelske tallord hos inuitt i Alaska og Canada, visse tallord fra tysk hos inuitt i Labrador og før i tiden også hos herrnhutiske menigheter i Grønland,

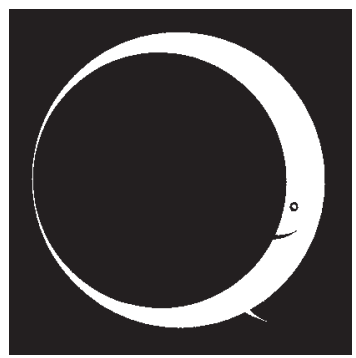
danske tallord i grønlandsk inuitt.

Samme forhold gjør seg også gjeldende for ordene for de tidligst importerte kolonialvarene, gjenstander og begreper. Yup'ik i Alaska har f.eks. mange ord for kolonialvarer og (kristelige) religiøse uttrykk fra den russisken perioden i Alaska. Mange inuittdialekter har dessuten omformet en rekke tekniske uttrykk til inuittspråk: qaammataasaq 'noe som fungerer som en slags måne' = satellitt; silakkuarun (iñupiaq) 'noe man gjør gjennom luften' = radio; nagguteeraq (grønlandsk) 'noe som ligner en tallerken med is' = skipskjeks (av elliptisk form). Det tok atskillige år å oversette begrepene 'synd' og 'hellig' til grønlandsk. 
Mange uttrykk er blitt alminnelige, f.eks. inussiarnersumik inuulluaqqusillunga - 'med vennlig hilsen'. Kalaallisuts agglutinerende orddannelse setter imidlertid snevre grenser for lån. Ikke alle uttrykksmåter kan innlemmes direkte i inuittspråket, og det er derfor kun få egentlig grammatiske lån $\mathrm{i}$ kalaallisut.

Gjennom flere hundre års samkvem med det danske og andre europeiske språk har man med tiden innarbeidet språklyder og lydregler som man tidligere ikke kunne bruke, derfor har man nå en rekke direkte fremmedord.

Som fremmedord anerkjenner man internasjonalt anvendte termer og betegnelser. Dog har man den muligheten å anvende et grønlandsk såkalt avløsningsord, dvs. et ord som er konstruert med kalaallisut-elementer for å dekke det samme begrepet som fremmedordet. Som eksempel på avløsningsord kan nevnes qarasaasiaq, computer (ordrett: 'en bearbeidet ting, som ligner en hjerne', jf. 'elektronhjerne').

Lånord er de ordene som er så integrert i grønlandsk språkbruk, at man ikke lenger oppfatter dem som fremmedord. De er blitt tilpasset det grønlandske språkets lydlige struktur: januaari, sukulupooq (skjørbuk), kaffi. Andre har man omformet til grønlandsk, slik at de ikke virker fremmede: sioraasat (melis, sukker), qarasaasiaq (computer), nagguaatsoq (elefant), pujorsiut/sammivissiut (kompass).

I den eksterne språkpolitikken setter man grønlandsk som hovedspråk, dansk og engelsk som henholdsvis første og andre tilleggsspråk.

\section{Språkets status}

Man har i den grønlandske debatten vært svært opptatt av kalaallisuts status. Vil språket fremover tape terreng til dansk og engelsk? Kan man eventuelt risikere at det helt forsvinner? Og kan en slik utvikling snus? I øyeblikket hersker det en viss optimisme. Kalaallisut lever som skriftspråk og blir ganske jevnlig brukt av alle samfunnsgrupper. Landstinget, den lovgivende forsamling, bruker det som sitt språk: Lovgivningen skrives, diskuteres og vedtas på grønlandsk. Mediene er tospråklige grønlandsk og dansk, og i kirken bruker kalaallisut. Man har gjennomført en grønlandisering av utdannelsessystemet slik at grunnskoleundervisningen i det store og hele foregår på kalaallisut, og språket brukes også i gymnaset. 
En annen viktig ting er at grønlendere når de tar videregående utdannelse, som regel begynner å bruke det grønlandske språket i arbeidet. Det er visse områder som handelsfag, tekniske fag, juss og ingeniørutdannelse hvor det er behov for å utvikle en grønlandsk terminologi, men den største utfordringen er å få erobret domenene også i de mellomlange og høyere utdannelsene: Kalaallisut i lærebøker til grunnskole, videregående skole, lærerskole og universitet og kalaallisut i selve undervisningen i all videregående utdannelse.

Språkets symbolske verdi er for stor til at man kan se bort fra det i de videregående utdannelsene og i rekrutteringen av grønlandskspråklig ekspertise i fremtiden.

Man har erkjent at kalaallisut ikke er statisk, og språket må sies å være i rask utvikling. Mens man andre steder kan telle tjue år mellom de språklige generasjonene, er det i Grønland snarere tale om fem-ti år mellom de språklige generasjonsskiftene. Men Grønland er også et ungt samfunn som fordrer å få service på eget språk. Fremtiden vil vise hvorvidt politikerne kan gjennomføre en grønlandiserende språkpolitikk i takt med at Grønland blir globalisert.

Oversettelse fra dansk: Gytte Borch

\section{Litteratur}

Kolte, Svend (1999): «Kalaallit Oqaasii

- det grønlandske sprog». Inuitt -

Kultur og Samfund. Systime.

Oqaatsivut kulturerpullu - vort sprog -

vor kultur. (Rapport og opplegg fra

kollokvium om språk og arkeologi.)
Nunatta Katersugaasivia/Grønlandsk

Landsmuseum og Ilisimatusarfik/

Grønlands Universitet 1986.

\section{Internett}

Om dialektfordeling og lydforandringer i grønlandsk:

www.oqaasileriffik.gl/documents/doc/joergen_rischel_dk.doc 


\section{Bestill boken på www.norden.org/agenter}

Pris DKK 95 (ekskl. moms). Det gis rabatt på klassesett. Prisen er veiledende og i danske kroner og kan derfor variere mellom salgsagentene våre i de forkjellige landene. Et ekspedisjonsgebyr kan også tilkomme.

SVENSK Nordens språk med rötter och fötter Nord 2004:8 ISBN 92-893-1043-X NORSK Nordens språk med røtter og føtter Nord 2004:9 ISBN 92-893-1042-1

DANSK Nordens sprog med rødder og fødder Nord 2004:10 ISBN 92-893-1041-3

ISLANDSK Norđurlandamálin međ rótum og fótum Nord 2004:11 ISBN 92-893-1040-5

FÆRøSK Norđurlandamál við rótum og fótum Nord 2004:12 ISBN 92-893-1039-1 